\title{
A 100-Year Review: A century of change in temperate grazing dairy systems ${ }^{1}$
}

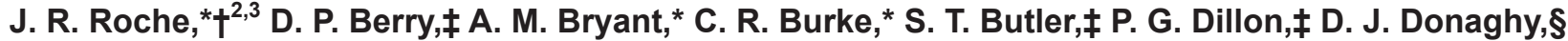 \\ B. Horan, $\ddagger$ K. A. Macdonald, ${ }^{*}$ and K. L. Macmillan\# \\ *DairyNZ Ltd., Private Bag 3221, Hamilton, New Zealand 3240 \\ †School of Biological Sciences, University of Auckland, Private Bag 92019, Auckland 1142, New Zealand \\ ¥Teagasc, Moorepark, Fermoy, Co. Cork, Ireland P61 C996 \\ §Institute of Veterinary, Animal, and Biomedical Sciences, Massey University, Palmerston North, New Zealand 4442 \\ \#University of Melbourne, Parkville, Victoria, Australia 3010
}

\section{ABSTRACT}

From 1917 to 2017, dairy grazing systems have evolved from uncontrolled grazing of unimproved pastures by dual-purpose dairy-beef breeds to an intensive system with a high output per unit of land from a fit-for-purpose cow. The end of World War I signaled significant government investments in agricultural research institutes around the world, which coincided with technological breakthroughs in milk harvesting and a recognition that important traits in both plants and animals could be improved upon relatively rapidly through genetic selection. Uptake of milk recording and herd testing increased rapidly through the 1920s, as did the recognition that pastures that were rested in between grazing events yielded more in a year than those continuously grazed. This, and the invention and refinement of the electric fence, led to the development of "controlled" rotational grazing. This, in itself, facilitated greater stocking rates and a 5 to $10 \%$ increase in milk output per hectare but, perhaps more importantly, it allowed a more efficient use of nitrogen fertilizer, further increasing milk output/land area by $20 \%$. Farmer inventions led to the development of the herringbone and rotary milking parlors, which, along with the "unshortable" electric fence and technological breakthroughs in sperm dilution rates, allowed further dairy farm expansion. Simple but effective technological breakthroughs in reproduction ensured that cows were identified in estrus early (a key factor in maintaining the seasonality of milk production) and enabled researchers to quantify the anestrus problem in graz-

\footnotetext{
Received May 17, 2017.

Accepted June 20, 2017.

${ }^{1}$ This review is part of a special issue of the Journal of Dairy Science commissioned to celebrate 100 years of publishing (1917-2017).

${ }^{2}$ Corresponding author: john.roche@dairynz.co.nz

${ }^{3}$ This paper was compiled by J. R. Roche from every author's contribution; other authors are listed alphabetically.
}

ing herds. Genetic improvement of pasture species has lagged its bovine counterpart, but recent developments in multi-trait indices as well as investment in genetic technologies should significantly increase potential milk production per hectare. Decades of research on the use of feeds other than pasture (i.e., supplementary feeds) have provided consistent milk production responses when the reduction in pasture intake associated with the provision of supplementary feed (i.e., substitution rate) is accounted for. A unique feature of grazing systems research over the last $70 \mathrm{yr}$ has been the use of multi-year farm systems experimentation. These studies have allowed the evaluation of strategic changes to a component of the system on all the interacting features of the system. This technique has allowed excellent component research to be "systemized" and is an essential part of the development of the intensive grazing production system that exists today. Future challenges include the provision of skilled labor or specifically designed automation to optimize farm management and both environmental sustainability and animal welfare concerns, particularly relating to the concentration of nitrogen in each urine patch and the associated risk of nitrate leaching, as well as concerns regarding exposure of animals to harsh climatic conditions. These combined challenges could affect farmers' "social license" to farm in the future.

Key words: rotational grazing, set-stocking, supplementary feeds, future issues

\section{PILLARS OF THE MODERN GRAZING SYSTEM}

Increased interest in grazing because of ease of establishment and a lower requirement for capital infrastructure, low operating expenses per kilogram of milk, and potential access to high-value markets because of perceived animal welfare benefits has led to a range of grazing systems being developed globally. However, the archetypal modern grazing system is that synonymous with New Zealand, Australia, and western Europe (e.g., France, Ireland, and the UK), all of which have a rich 
history of agricultural science that has contributed to the development and refinement of a very efficient system over the last century.

Dairy grazing systems are designed to grow large yields of digestible forage, generally grass-legume mixtures, and harvest a high proportion of the "pasture" grown directly by the cow. The requirement for machinery and housing and associated expenses are minimized (Roche et al., 2017b). This is primarily achieved by (1) ensuring optimal soil fertility and appropriate use of nitrogenous fertilizers; (2) matching the feed demand of the herd with the annual pasture supply profile (i.e., seasonal milk production) through strategic decisions around calving date and stocking rate; and (3) designing the farm infrastructure of paddocks and cow tracks or lanes to facilitate easy access to pasture (Roche et al., 2017b). Even with all these, success is still dependent on adequately drained soil types resistant to treading damage. In many countries, significant government investment in large-scale drainage schemes and irrigation channels has increased the possibilities for grazing systems in otherwise unsuitable areas.

Ideally, more than $90 \%$ of the herd (including replacement heifers) calve within a 50- to $60-\mathrm{d}$ period, with the end of calving coinciding with the time that pasture growth equals herd demand (Dillon et al., 1995; Roche et al., 2017b). Virtually all modern intensive grazing systems use rotational grazing practices, wherein the cows "rotate" around a sequence of paddocks (i.e., an enclosed grazing area) linked by farm tracks, allowing each paddock to recover from the stress of grazing and take advantage of the exponential phase of growth, at least for temperate grass species (Figure 1). This system also has the labor advantages of collecting cows for milking from a small confined area (e.g., 1 ha) compared with a system where cows have free access to the entire farm or large areas of it (the alternative grazing method of "set-stocking"). Feeds imported from offfarm (i.e., supplementary feeds) are incorporated into grazing systems to provide nutrients during periods when pasture growth rates are less than feed demand. Pasture surplus to requirements in spring and summer can be conserved as silage or hay and offered to cows during periods of low pasture growth, particularly to nonlactating cows during winter. For this system to function optimally, the cow must be highly fertile and have good grazing behavior characteristics.

This system evolved over the last $100 \mathrm{yr}$ through independent and collaborative research undertaken by many researchers in many countries (Appendix Table A1). Key principles contribute to the biological and economic success of this grazing systems and these were described by C. P. McMeekan in his landmark treatise, Grass to Milk (McMeekan, 1960):

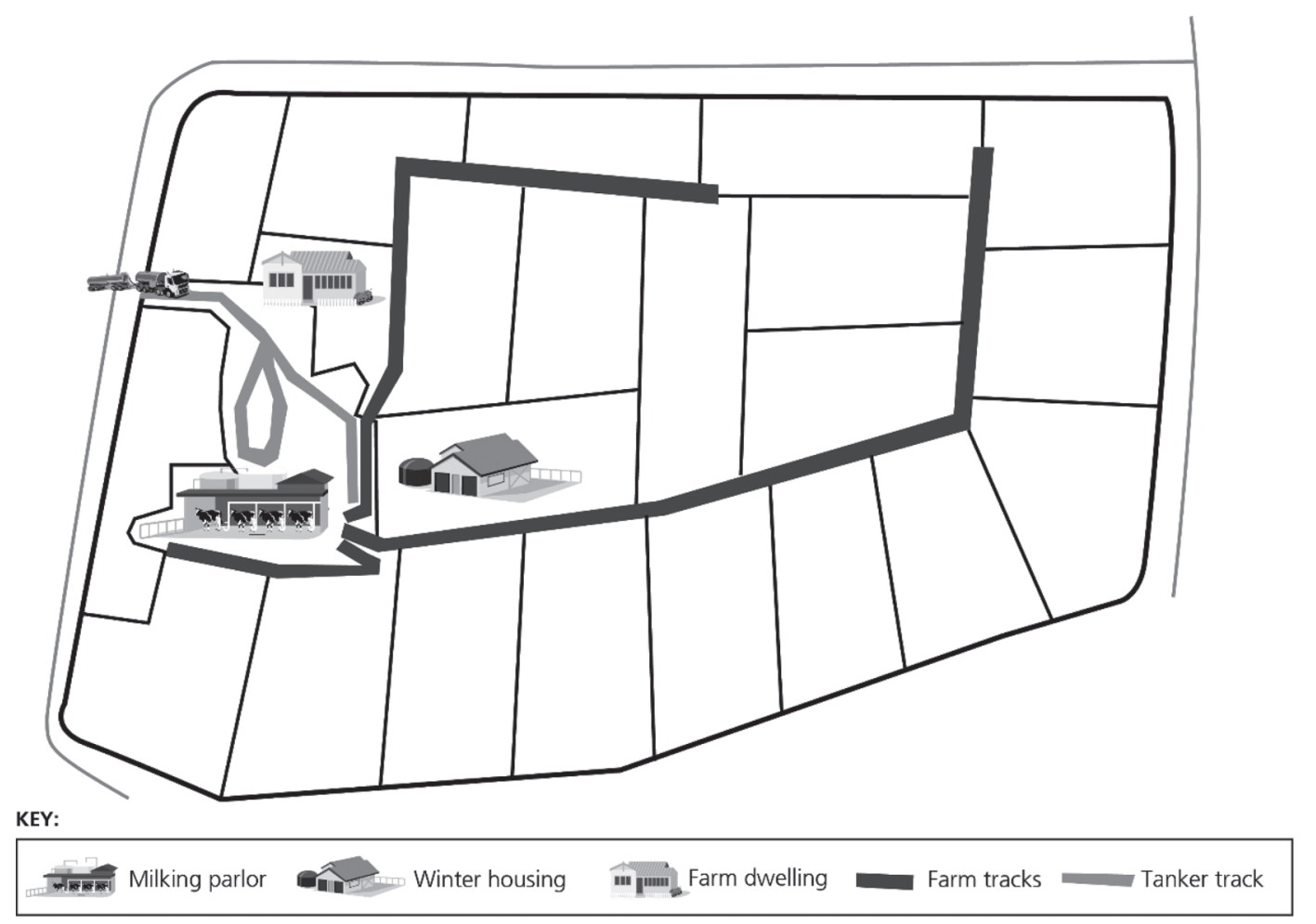

Figure 1. A typical layout of a modern grazing dairy farm. Reproduced with permission from Roche et al. (2017b). 
- grow as much pasture as economically practicable;

- carry enough stock to use all the grass grown;

- adjust the variable supply of fodder to the needs of the herd;

- use animals that will process the grass efficiently; and

- minimize herd wastage by control of disease.

The research that led to the development and the continual refinement of these principles over the last 100 years is the subject of this review.

\section{WHERE IT ALL BEGAN: GRAZING DAIRY SYSTEMS IN 1917}

The majority of dairy systems in 1917 involved some level of grazing, but there had been little gain in the efficiency of this component of the system in the previous 200 yr (Blaxter and Robertson, 1995). Most farms tended to have a few fields, but, unlike the modern rotational grazing system, these were typically "night and day" fields, to reduce the amount of walking done by the cows and by the farmer in the morning rather than for any biological advantage. In fact, such a practice often led to the transfer of nutrients from the "day" field to the "night" field. In many countries, the majority of cows were still milked by hand, limiting the number of cows on any farm to the number of people available for milking. Calving was year-round to ensure a continuous milk supply to the creamery or milk factory. Grazing practices were rudimentary and a key aim was to conserve hay during late spring and summer to use as feed in winter when pasture growth was slow or zero.

Over the last $100 \mathrm{yr}$, grazing research programs have addressed key aspects of pasture-based systems of milk production, including grazing management, stocking rate, dairy cow genetics, dairy cow reproduction, milking and milk quality, dairy cow health and welfare, as well as bio-economic modeling. A unique feature of the research undertaken in grazing systems has been the use of multi-lactation "farm systems" experiments, wherein small farms (i.e., farmlets of 20-50 cows) are established for 3 or more years and changes to a particular component of the system evaluated (e.g., stocking rate; Macdonald et al., 2008a; McCarthy et al., 2016). This research methodology has provided valuable insight into the interactions between components of a farm and enabled an understanding of the farm system implications from changing a single component of a grazing system.

A further principle, particularly evident in grazing systems today, which was eloquently relayed by C. P. McMeekan, was that "research was useless unless it was applied" (Scott, 1997). This tradition of con- nectedness to the farmer has continued in much of the grazing research undertaken, with a strong focus on applied research questions and trial design, the testing of component-level changes in multi-year farm systems experiments, demonstration and farmer-partner farms, and the dissemination of experimental results directly by scientists.

\section{INFRASTRUCTURE DEVELOPMENTS}

Although grazing is a relatively simple and technology-free system of farming, key developments in the evolution of the grazing system were borne out over the past $100 \mathrm{yr}$ and were instrumental in its success. These developments facilitated intensive management strategies (Macdonald and Penno, 1998) and, importantly, the expansion of grazing dairy farms to maintain viability at scale. The 3 most important technological breakthroughs did not occur in the laboratory or in some engineering factory, but were the product of necessity and farmer ingenuity.

The most obvious example is in the development of the electric fence, which in effect allowed the corralling of dairy cows on small areas and facilitated the resting of grazed pastures. This technological development paved the way for rotational grazing. The manufacture and sale of electric fence "chargers" began in the United States in the early 1930s and an estimated 70,000 were in operation by 1938 (Jones, 1988). In 1936, Bill Gallagher, a New Zealand farmer, read about the development of these energizers and made one to control the dairy cows on his farm. Two years later, he sold the farm and started manufacturing the energizers commercially; in 2017, Gallagher is, arguably, the most globally recognized name in electric fence manufacture and sales.

However, the fences were prone to "shorting" (losing power) and could not be used over long distances, therein limiting their usefulness to small farms. If farms were to increase in size, a new type of fence had to be developed. In the 1950s, Doug Phillips at Ruakura (Waikato, New Zealand) developed the "unshortable" fence, so named because it could be used without any insulated supports (Jones, 1988). The Waikato energizer, as Phillips' invention came to be known, allowed large areas of pasture to be fenced for rotational grazing but at approximately $10 \%$ of the cost of conventional fencing. Large areas could be fenced, allowing large numbers of cows to be managed on one farm; in Phillips' own words, "it was a revolution in grassland farming."

Two other farmer inventions also pioneered the way for increasing scale in grazing systems. At the beginning of the 20th century, most cows in most countries 
were still hand milked, and the number of cows in the herd was dependent on the number of people available for milking. Feeding, although laborious in winter when cows were stanchioned, was "self-service" during the grazing season. Therefore, most grazing farms needed less labor per cow than an equivalent housed system for most of the year. Nevertheless, the milking routine was time consuming. Although prototype milking machines had been developed, they were, for the most part, unaffordable and relatively inefficient.

Many improvements to the reliability of the vacuum pump and pulsators during the early part of the 20th century and an increased requirement for milk cleanliness and concerns around the spread of zoonoses improved the efficiency and uptake of the technology. For example, it is estimated that more than half of New Zealand's cows were milked by machine by 1920 (McCloy, 2014). Even with perfect technology, however, the design of the milking sheds or parlors slowed the milking routine. The "walk-in" shed, wherein cows were led into the bail by the milker, tethered, milked, released, and reversed out of the bail, and kept separate from herd mates waiting to be milked, led to a slow and labor-intensive procedure. The walk-in shed was replaced by the "walk-through" milking parlor, where the process was the same except that cows did not have to reverse out of the stall after milking and could exit through a gate at the front of the stall and return to the pasture. This simple change in parlor design reportedly allowed a single milker to machine milk up to 42 cows in an hour.

Despite the large improvement, the walk-through milking parlor did not allow for a significant increase in farm size. The economic turmoil associated with the Great Depression in the 1930s and World War II in the 1940s limited investment and innovation. A serendipitous discovery in the early 1950s, however, was to revolutionize milk harvesting. Ron Sharp, a dairy farmer from near Hamilton (Waikato, New Zealand) noticed the new $60^{\circ}$-angle car parking system that was introduced to the city after the war. He went home and investigated the application of a similar design in his milking parlor. Groups of cows would file through the alley and "park" themselves at approximately $60^{\circ}$ angles to each other. The milker would stand in a sunken pit behind the cows and attach the milking cluster. Once milking was finished, the cows would exit from the other end of the shed and another batch would come in to take their place (McCloy, 2014). The herringbone milking parlor was born. Sharp's design was so successful that, within $15 \mathrm{yr}, 70 \%$ of milking parlors in New Zealand used a similar design, and milking efficiency increased from 42 to 70 cows/milker per hour. This was the first parlor design to take the "spancel" off the farmer and allow them to manage a much larger herd. (A rope "spancel" is used to restrain a cow with a propensity to kick during milking, by tying a back leg to the railing.)

In a similar vein of ingenuity, another New Zealand farmer, Merv Hicks, decided that cows were not comfortable parked up against each other in the herringbone design; he believed that they needed to be separated during milking. He designed a milking parlor in which each cow had its own bail, like the slow and laborious walk-in milking parlor design, but that rotated the cows in a circle during milking, like a carousel in a children's playground. At the completion of one full rotation, cows would reverse off the turning platform. In such a simple but ingenious way, the rotary or carousel dairy was invented.

All of these inventions have been upgraded with improvements in engineering and design and the ability to add complementary technologies, such as automatic cow identification and in-parlor individual cow or flat-rate feeding systems. In essence, however, the unshortable electric fence and the herringbone and rotary designs remain the same today as when envisioned by their inventors. Farmers also focused on selecting cows for temperament and milking speed; although both were also, arguably, a large focus of culling when cows were hand-milked, with scale came the requirement for speed and an intolerance for cows that disrupted the routine and increased the risk to milker health and safety.

\section{Summary}

If grazing dairy farms were to be financially and socially sustainable, there was a need for scale and for machines to undertake the most laborious tasks, not to mention the need to control feed management. It is said that necessity is the mother of invention, and the inventions that facilitated expansion in grazing systems came, primarily, from farmer ingenuity and the keen observation skills of applied scientists who improved upon their ideas. Furthermore, however, the speed of uptake of these technologies was evidence of the maturity of the industry and the recognition that dairy farms could be expanded to 100 cows and beyond.

\section{PASTURE AND GRAZING RESEARCH}

The first principle of a successful grazing system relayed by McMeekan (1960) was to "grow as much pasture as economically practicable." During the 100-year period considered in this review, significant research efforts have focused on defining optimum soil concentrations of required minerals and identifying the factors influencing pasture growth, quality, and utiliza- 
tion. The International Grassland Congress was established in 1927 as an outlet for scientists to discuss and debate the results of field experiments. The congress has met 23 times since then and on every continent except Africa. The congress covers a myriad of disciplines underpinning grazing systems. Plant genetics and soil constraints have been a feature of the congress since 1927, representing 30 to $40 \%$ of the papers presented at each event, but plant physiology became more important in the 1960s, 1970s, and 1980s, the nutritive value of forages increased in prominence from the 1960s onward, and grazing systems became a significant part of the congress from the mid-1950s onward (Humphreys, 2005). The considerable research efforts undertaken in this time and discussed at length in these conference proceedings have been distilled into practical strategic and tactical grazing management practices that are taken for granted in modern grazing dairy production systems.

\section{Soils and Fertilizers}

Taxonomic characterization of soils was undertaken globally through the first half of the 20th century (Blaxter and Robertson, 1995), and this allowed more targeted research toward optimizing soil fertility. In 1917 , it was recognized that soil fertility was the key limiting factor in the successful establishment and production of ryegrass and clover pastures (Cockayne, 1912a,b). Elting and Lamaster (1934) reported that lime and phosphorus were "the only profitable fertilizer treatment for pasture." The application of lime alone increased pasture yields by $34 \%$, whereas application of phosphorus increased DM yield by $41 \%$; applying both increased per hectare DM yields by $79 \%$ compared with untreated controls. Nevertheless, customized soil nutrient recommendations were still a half-century away.

Activities in soil science and fertilizer increased in universities, colleges of agriculture, and in research stations and government agencies devoted to the subject from the 1930s. In 1933, the Soil Erosion Service (precursor to the Natural Resources Conservation Service) was established in the United States, as a direct response to the soil erosion phenomenon that became known as the "Dust Bowl" and following the establishment of soil erosion experiment stations in 1929. Their very detailed surveys of soil classification and land-use capability remain valuable today in identifying appropriate land use and fertilizer recommendations. Around the same time, the national Soil Survey Departments were established in the United Kingdom (Blaxter and Robertson, 1995).

During the 1920s and 1930s, fertilizer application rates were derived from "local experimentation" and demonstration. Farmyard manure remained an important source of nutrients for grassland pastures, with responses from hundreds of experiments across Britain and Ireland reported by the early 1940s (Boyd and Lessells, 1954): pasture production increased by $58 \mathrm{~kg}$ of $\mathrm{DM} /$ ha per $1 \mathrm{t}$ of farmyard manure. By the 1940s, a comprehensive series of fertilizer mixtures were being produced, and extra nitrogen, phosphorus, and potassium $(\mathrm{N}, \mathrm{P}, \mathrm{K})$ were allocated in addition to farmyard manure (Blaxter and Robertson, 1995). By the early 1950s, $22 \%$ of grassland area was receiving farmyard manure, whereas 32,35 , and $21 \%$ were receiving $\mathrm{N}$-, $\mathrm{P}-$, and K-containing fertilizers, respectively (Boyd and Lessells, 1954). In truth, however, the application rates were low: $34 \mathrm{~kg}$ of $\mathrm{N}, 80 \mathrm{~kg}$ of $\mathrm{P}_{2} \mathrm{O}_{5}$, and $44 \mathrm{~kg}$ of $\mathrm{K}_{2} \mathrm{O}$ per ha per year, and the majority was applied to meadows for hay and silage crops and not specifically for grazing.

By the 1960s, soil maps were developed for the different pasture-growing regions of the world. With soils classified for the different grassland regions, optimum soil $\mathrm{P}, \mathrm{K}$, and $\mathrm{S}$ concentrations and soil $\mathrm{pH}$ for different soil types were defined with more precision (Roberts and Thomson, 1988; Daly et al., 2001; O'Connor et al., 2001; Dougherty and Gourley, 2014). Nitrogen fertilizer experimentation for grassland farming began, in earnest, in the 1950s and 1960s, with myriad experiments investigating the interaction between nitrogenous fertilizers and grass and legume species, soil temperature, and moisture availability on pasture DM yield and quality (Whitehead, 1995) and on cow health and milk production (de Groot, 1963). The increased understanding of the soil's needs was accompanied by great advancements in the ability to manufacture fertilizers and a large increase in the use of chemical fertilizers; for example, in the $50 \mathrm{yr}$ from 1930, the use of $\mathrm{N}, \mathrm{P}$, and $\mathrm{K}$ increased 20-, 2.5-, and 6-fold, respectively, in the United Kingdom (Blaxter and Robertson, 1995), although, admittedly, much of this increased use was for growing crops and not for pasture production.

In conclusion, from a dearth of knowledge on soil taxonomy and chemical composition in 1917, we have established a worldwide classification system of soils and an understanding of the slope and inflection points of pasture growth in response to increasing soil mineral concentrations. As a result, we have sensible recommendations in almost all pasture-based industries on economic use of fertilizers on different soil types.

\section{Pasture Breeding and Establishment}

After World War I, much land that had been cultivated for cereals during the war was returned to grassland pastures (Lazenby, 1981), and post-war 
governments were keen to support research in food production (Blaxter and Robertson, 1995). Following the establishment of the Welsh Plant Breeding Station at Aberystwyth in 1917 under the direction of George Stapledon, plant breeding for grazeable forages became the focus (Lazenby, 1981). The importance of leaf and leaf-to-stem ratio on plant digestibility was quickly recognized (Stapledon, 1924) and became a focus of plant breeding, as did breeding for usage (e.g., upright for haymaking, more prostrate for grazing; Lazenby, 1981; Raymond, 1981). The New Zealand Plant Research Station was set up in 1928, and Bruce Levy began a trial to identify superior strains of ryegrass and white clover for New Zealand conditions. Levy was a champion of intensive grassland management, advocating heavy use of superphosphate and higher stocking rates and recommending pasture improvement by sowing the best grass and clover species.

In the 1920s, the placement of grass seed in furrows alongside fertilizer was tested, mimicking the establishment of cereal crops. Although the practice improved pasture establishment in sandy soils and with low-density pasture species compared with the more commonly applied surface broadcast of seeds, it was not an effective way of establishing high-density pastures, a trait identified as being important for grazing (Stapledon, 1927a,b,c). In 1953, the sod-seeder was developed and patented at the University of Sydney, Australia, which allowed more accurate seeding of pastures in a range of soil types.

A grass seed certification scheme was introduced into New Zealand in 1929 to ensure the purity and germination of pasture seeds (Hunt and Easton, 1989) and to aid in plant breeding efforts. In 1961, plant variety rights legislation was introduced in Europe, following a meeting of plant breeders in Paris, which increased the rate of introduction of new pasture varieties and cultivars (Raymond, 1981); similar legislation was subsequently introduced in the United States (1970), New Zealand (1973), and Australia (1987). As a result of this initiative, merit testing of varieties and cultivars began in earnest in the 1960s, and qualitative and quantitative data were collected to produce a description of a pasture variety or cultivar's relative position against its peers.

In 1965, an influential British farmer claimed that stocking rate and nitrogen fertilizer were more influential than seed mixtures or the age of pastures (Paterson, 1965), highlighting a perceived lack of progress, at least at the farm level, in pasture genetics. This perception was not fully accurate. Research plot growth trial results indicate that annual DM yield increased by $0.52 \%$ per year under conservation and $0.35 \%$ under simulated grazing, with similar gain levels within maturity groups or ploidies (McDonagh et al., 2016). Furthermore, Woodward et al. (2001), in a novel experiment that compared the effect of 1960s and 1980s ryegrass and clover cultivars on milk production in a multi-year farm systems study, reported significant gains in clover breeding, although newer ryegrass cultivar varieties did not perform as expected. The apparent contradiction between the studies may reflect the timing of the increased pasture DM production, which has largely occurred in spring, when pasture cannot be consumed directly by the cow and converted to milk.

In response to these results, and recognizing that other pasture-level traits are important to profitability, considerable efforts have been made to establish multitrait genetic improvement indices for grasses during the last decade. In both Ireland (2011; Pasture Profit Index) and New Zealand (2016; Forage Value Index), indices have been developed and national phenotype databases have been established to ensure that seasonal DM production, nutritional profile, and persistency traits are adequately represented and appropriately weighted from an economic perspective. These initiatives are a major step forward in addressing the historical lack of genetic gain in pasture species and cultivars.

\section{Pasture-Endophyte Relationships}

Microscopic fungal endophytes live symbiotically within grass hosts where they confer protection againts insect herbivores through the production of alkaloid compounds. Unfortunately, these same compounds can have negative effects on animal health and productivity if eaten in sufficient quantities by dairy cattle.

References to endophyte toxicoses date back to Biblical times (approximately AD50; Bacon, 1995), although their influence must have predated written history. The first ryegrass endophyte was discovered in Australia in 1920 (McLennan, 1920), but it was 1940 before it was reported in New Zealand ryegrass plants (Neill, 1940). Similarly, the true extent of endophyte toxicosis was defined in tall fescue in the 1940s in the United States. In the decade following its release in 1943, millions of hectares of Kentucky-31 tall fescue were established in the southeastern United States (Mueller, 1986). It soon gained a reputation for causing livestock health problems and reduced animal performance (Pratt and Haynes, 1950; Blaser et al., 1956) and was regarded by dairy farmers as an unpalatable grass that was not suitable for milking cows (Mueller, 1986). This affected the growth of dairy grazing systems within much of the eastern United States, because no other cool-season perennial grass was widely adapted and persistent (Hoveland, 2009). 
So bad were the toxicoses in some grass species-endophyte symbioses that Cunningham (1948) claimed that tall fescue was poisonous to cattle, although he retracted this claim when he discovered no adverse effects from feeding grass seeds inoculated with endophyte to birds and rodents (Cunningham, 1958). In the 1980s, it was categorically proven that the alkaloid compounds produced by endophytes cause "ryegrass staggers" during spring in dairy cattle (note: this is different from hypomagnesemic grass staggers) and heat stress during summer. In the United States, high endophyte Kentucky-31 was reported to reduce milk production and increase rectal temperature (Strahan et al., 1987), and Baxter et al. (1986) reported a greater milk yield in orchardgrass pastures than in fescue pastures infected with endophyte. In ryegrass, the alkaloid lolitrem B was isolated as the causal factor for ryegrass staggers (Gallagher et al., 1981; Harvey, 1983), whereas ergovaline was isolated as the compound contributing to vasoconstriction and heat stress during summer. Endophyte-free pastures, however, were not an option, as endophytes were reported to provide protection from pasture pests, such as the Argentine stem weevil, and to enhance seedling establishment (Popay and Rowan, 1994).

Although severe when occurring, the effects of endophyte were short-lived and it was unclear what actual effect the alkaloids had on animal production. Clark et al. (1999) reported inconsistent effects of endophyte on milk production in a series of short-term experimentsa $4 \%$ reduction in milk and milk fat yield from cows grazing high-endophyte perennial ryegrass pastures was reported during one spring but these effects were not repeated in the subsequent spring and the effect was reversed in autumn, with the cows that grazed high-endophyte pasture producing higher milk yields. Nevertheless, the debilitating effects of the endophyte alkaloids on animals could be severe at times and there was increased pressure to find a solution. Techniques were developed to identify desirable endophytes that conferred protection against insect attack but lacked the debilitating effects on animals. These "novel" endophytes, as they became known, were inoculated onto endophyte-free seed. Bluett et al. (2003) evaluated one of the first of these novel endophytes (AR1) and reported a $9 \%$ increase in average milk production over 3 lactations compared with the wild-type endophyte, encouraging scientists to develop other varieties. Multiple varieties of novel endophytes have been delivered since the 1990s that provide significant protection against insect attack, while possessing less of the secondary compounds that cause ryegrass staggers and vasoconstriction-related heat stress (Milne, 2007).

\section{Grazing Management-The Path Toward Rotational Grazing}

In 1927, Stapledon reported that increasing the period of rest of a pasture between defoliations results in increased DM production (Stapledon, 1927c) and these findings were subsequently confirmed by others (Woodman and Norman, 1932). At the same time, however, Woodman and colleagues (Woodman et al., 1928, 1929, 1931; Woodman and Norman, 1932) reported that more frequent defoliations resulted in higher quality feed. Nevertheless, they concluded that pasture DM production was positively associated with digestible OM production, suggesting that a suitable rest period might exist that accommodates the increased DM production and maintains feed quality.

Detailed plant physiology experiments further supported the advantage of resting pastures for a period after grazing. In a comprehensive review of the role of stored energy reserves in plants and their mobilization following grazing, Weinmann (1948) established a need for a rest period between defoliations to allow plants to replenish carbohydrate stores used in regrowth. Subsequent experiments in the 1950s confirmed a greater pasture DM yield per hectare with an increase in rest period length between defoliation events (Raymond, 1981). These studies led to the idiom that "grass grows grass," which meant that the increase in pasture growth with increasing rotation length was not linear but exponential. Brougham (1955) confirmed this when he concluded that, following grazing, grass grows in a sigmoidal (S-shaped) pattern, beginning slowly and increasing exponentially to a ceiling yield, above which tissue death equals growth and there is no further increase in green digestible material. This sigmoidal curve was subsequently made famous by Voisin in his textbook Grass Productivity (Voisin, 1959). Later studies confirmed that DM yield was depressed under fast grazing rotations and this effect was more marked in summer (Campbell, 1969). In comparison, slower rotations increased DM yield, particularly during autumn and winter, when pasture growth rate was slow.

These experiments led to the hypothesis that animal production should be higher from intermittently grazed swards (i.e., controlled or rotational grazing) than continuously grazed swards (i.e., uncontrolled or set-stocking). Subdivision of larger farm areas into smaller paddocks (i.e., a grazing area) and utilization of rotational grazing were reported as widespread in New Zealand a decade earlier (Holford, 1937). The advancement of rotational grazing was facilitated by the development of an electric fence in the early 1930s and subsequent improvements to facilitate longer 
fences and more consistent voltage (Jones, 1988). In 1952, the "New Zealand grazing system" was outlined by McMeekan (1952) as one that employs "controlled rotational grazing," based on alternately grazing and resting the pasture to

- increase total yield;

- maintain pasture in a leafy state; and

- aid utilization by grazing stock.

Despite this clear acceptance of rotational grazing by farmers, researchers in many countries debated whether this investment in technology and resting of pastures would increase productivity.

The first experiments in support of rotational grazing were reported by McMeekan (1947). Calves managed in a rotational grazing system were $27 \mathrm{~kg}$ heavier entering their first winter (approximately 9 mo of age) than calves raised under set-stocking and, as a result, had a substantially reduced mortality rate. By the time of their first calving, there was a $63-\mathrm{kg}$ difference in BW in favor of the rotationally grazed heifers.

McMeekan (1947) also reported that rotational grazing resulted in a $26 \%$ per year advantage in milk fat yield in lactating dairy cows compared with set-stocking. This early support for rotational grazing was challenged, however, by subsequent research at Ruakura, wherein near identical milk production was reported from cows in either rotational or set-stocking management systems. It was hypothesized that the conflicting experimental results related to an interaction between grazing management strategy and stocking rate (McMeekan, 1960) and, in 1957, McMeekan reported a $13 \%$ increase in milk fat production per hectare under rotational grazing at higher stocking rates (McMeekan, 1957). Mott (1960) also concluded that the apparent difference between experiments related to an interaction between stocking rate and grazing management technique. He reported that milk production per hectare continued to increase with stocking rate, well beyond the point at which milk production per cow declined. In fact, maximizing milk production per hectare was associated with a $12 \%$ reduction in per cow DMI. The promotion of rotational grazing's superiority over continuous stocking in enabling an increase in stocking rate and milk production per hectare was confirmed in a multi-year experiment in the United States (Bryant et al., 1961a). They reported that rotational grazing increased the stock-carrying capacity by between 20 and $30 \%$ and increased milk production per hectare, although the effect was dependent on the grazed pasture species.

The debate, in essence, was settled by the publication of a joint New Zealand-Irish collaboration. McMeekan and Walshe (1963) confirmed the interaction between grazing system and stocking rate in a 4-yr experiment; rotational grazing increased milk fat production per hectare by $7,6,22$, and $29 \%$ (in years 1 to 4 , respectively) at the high stocking rate. Interestingly, though, their work also implied an interaction between grazing strategy and time, with the low-stocked rotational grazing system producing 10 to $12 \%$ more milk fat/hectare than the set-stocked system in years 3 and 4 of the experiment; it was as though the benefits of rotational grazing at low stocking rates were not achieved for several years. The work also highlighted the necessity of multi-year experiments when evaluating significant system-level changes.

\section{Determining the Appropriate Time to Graze}

In conjunction with the acceptance of rotational grazing, between the 1960s and the 1980s, scientists in many countries made significant efforts to define criteria by which farmers could decide the appropriate time to graze and when cows should be removed following grazing. A variety of sward height and mass measurements were evaluated (L'Huillier and Thomson, 1988; O'Donovan et al., 2002):

- compressed sward height, using a disc or plate;

- undisturbed sward surface height, using a ruler;

- extended tiller height, again using a ruler but extending the full leaf before measuring height;

- the capacitance probe to estimate mass; and

- visual estimations.

Compressed pasture height measurements and associated regression equations to estimate pasture mass have been the most commonly used methodology, although O'Donovan et al. (2002) reported that visual estimation was the most accurate method of pasture mass determination, provided the observer was trained using calibration cuts. Nevertheless, all of these methods simply ranked pastures on height or estimated mass; none considered the appropriate time for grazing from a plant morphology or physiology perspective.

Since the 1970s, there has been an increased effort to understand the management of pasture that optimizes pasture DM production, utilization, and animal requirements. This research built on the recognition that plant stores were important in the regrowth of swards after grazing, but recognized that the length of the rest period for pastures must also be managed to maintain nutritive quality. Tainton (1973) reported that ryegrass-white clover pastures should not be grazed beyond the development of a full canopy (termed canopy closure), as growth rates decline rapidly at this point, 

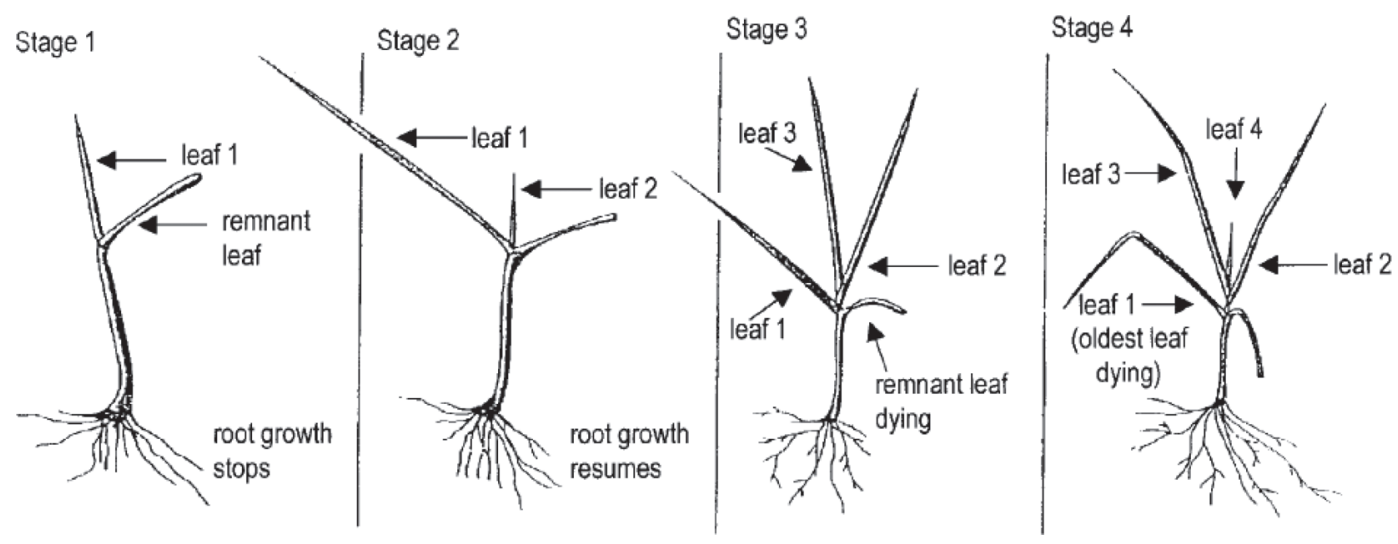

Figure 2. Regrowth of a ryegrass tiller following defoliation (source: Donaghy, 1998).

the rate of leaf senescence increases, and tiller density declines. Having defined that ryegrass maintains only 3 live leaves (i.e., it is a 3-leaf plant; Figure 2; Donaghy, 1998), Davies (1977) proposed that a ceiling yield is reached after emergence of the third new leaf. This provided a morphological basis for grazing management; the optimum point for grazing is between the adequate replenishment of plant stores and canopy closure. However, there was very little uptake of this management strategy for a further 15 yr. Fulkerson et al. (1993) first applied "leaf regrowth stage" as a grazing management strategy and, after a decade of research, recommended that, at least for perennial ryegrass, the "2-leaf stage" of regrowth sets a lower limit to grazing, because it facilitates the replenishment of the plant's carbohydrate stores, whereas senescence of the oldest leaf (i.e., $>3$-leaf stage of regrowth) sets the upper limit. These recommendations have been widely accepted as the way to maximize the yield of digestible pasture per hectare (Fulkerson and Donaghy, 2001).

\section{Postgrazing Residual}

The other principle identified by McMeekan (1960) as being important to the success of a grazing system that relates to grazing management was "to use all the grass grown," which in management terms refers to optimizing the postgrazing residual. This is a fine balance between harvesting the pasture grown but not undermining future growth potential by grazing too severely (i.e., over-grazing) and not underfeeding the cow to the detriment of milk production. Brougham (1957) reported that defoliation events that removed all of the leaf resulted in slow regrowth and Lee et al. (2008a) confirmed that consistent low postgrazing residuals $(\sim 2 \mathrm{~cm})$ reduce annual DM production. It is unlikely, therefore, that McMeekan meant his advice literally. He more than likely meant that the astute grassland manager should use as much of the grass at each grazing as is consistent with maximizing longterm total pasture consumed. To this end, Lee et al. (2008a) identified that there was little effect of postdefoliation residual heights between 40 and $80 \mathrm{~mm}$ on subsequent pasture DM production, but indicators of nutritive value (i.e., $\mathrm{CP}, \mathrm{ADF}, \mathrm{ADF}$ as a \% of $\mathrm{NDF}$, DM digestibility, and ME) changed through time and reflected a general decline in feed quality with increasing postgrazing residual.

Because pasture DM production is regarded as largely insensitive to postgrazing residual within the normal ranges in a dairy production system, the focus of grazing residual research and discussion has largely revolved around effects on animal production. Individual cow DMI (Cohen et al., 2000) and milk yield (Wales et al., 1999) are influenced primarily by the amount of pasture offered per cow on a daily basis; the higher the allowance, the greater the pasture DMI and milk yield, but the size of the increase declines with increasing allowance.

Because the increase in DMI with increasing allowance is less than unity, however, postgrazing residual height and mass also increase with allowance. Stakelum and Dillon (1991) highlighted that high postgrazing residuals in spring resulted in a subsequent reduction in $\mathrm{OM}$ digestibility and the proportion of green leaf in the sward. Because of the reduction in pasture quality, subsequent DMI and milk production declined, despite cows being offered the same green leaf allowance. In subsequent work, they reported that milk yield was 1 to $3 \mathrm{~kg} / \mathrm{d}$ less from cows grazing pastures that had previously had high residuals, unless pastures were mown and grazing pressure was reduced (Stakelum and Dillon, 1991). 
These results are consistent with US research that investigated the difference in milk production when cows were allowed to graze either the top or the bottom of the sward reported by Bryant et al. (1961a); cows grazing the top of the sward produced $30 \%$ more milk per day than those grazing the bottom of the sward, highlighting the difference in nutritive value between the leaf and the stem. It was, therefore, imperative to avoid stem elongation through excessive postgrazing residuals. Stakelum and Dillon (1991) concluded that low residuals were very important in spring but less important from summer on. Lee et al. (2008b) reported that consistent postgrazing residuals were the key. They reported that milk yield and presumably DMI were not affected by postgrazing residuals between 41 and $59 \mathrm{~mm}$ during a single rotation in spring, as long as the target residual was the same as that achieved previously. These results are consistent with Norton (2014), who reported no effect of grazing residuals between 35 and $50 \mathrm{~mm}$ on either milk production or the marginal milk production response to supplementary feeds. Nevertheless, these previous studies focused on animal production, with scant regard for per hectare production. Ganche et al. (2013a,b), in contrast, concluded that consistent postgrazing residuals of $35 \mathrm{~mm}$ maximized pasture DM yield and milk production per hectare. In summary, there is general agreement that postgrazing residual is important for subsequent pasture quality and milk production/cow. The optimum postgrazing residual is, however, poorly defined; nevertheless, it is likely between 35 and $50 \mathrm{~mm}$ (Ganche et al., 2013a,b; Norton, 2014).

The research investigating optimum postgrazing residual height and mass forms yet another argument in favor of rotational grazing over set-stocking. In setstocking, it is not possible to establish a consistently low average postgrazing residual (i.e., high utilization), because some areas of the pasture become overgrazed or grazed excessively frequently (Lee et al., 2010), whereas other areas are not adequately utilized. The move to rotational grazing allowed, for the first time, the ability to have low average postgrazing residuals without overgrazing certain areas, because the area offered/ animal was controlled (i.e., choice was removed) and the animals were moved after a short duration (e.g., a day), ensuring that the grazed pasture had time to fully recover between grazing episodes.

\section{Practical Outcomes of Grazing Research}

The grazing research undertaken over the last $100 \mathrm{yr}$ has had a significant influence in defining the modern system and in achieving 2 of the principles outlined by
McMeekan (1960): "grow as much pasture as is practicable" and "use all of the pasture grown."

The need for a rest period resulted in the acceptance of rotational grazing as being superior to set-stocking; this has facilitated various productivity improvements:

- greater pasture DM production per hectare, through exploiting the sigmoidal nature of pasture growth and the replenishment of pasture plant carbohydrate stores;

- greater ability to manage higher stocking rates by avoiding the "feast and famine" that would occur if pasture could not be rested between grazing events, particularly when pasture growth rates are low;

- more targeted and efficient use of $\mathrm{N}$ fertilizer because applications can closely follow grazing events.

The research into "ceiling yield" allowed the extension of research-derived recommendations for rotation length and grazing management decisions from any country to all temperate grazing areas.

Furthermore, it led to the refinement of the "autumn rotation planner" (Macdonald and Roche, 2016). In the $1960 \mathrm{~s}$, very long rotations were recommended in autumn $(>120$ d) to ensure sufficient feed was available in the winter. This did not increase the availability of digestible feed, as senescence and new growth were equivalent, but it led to a reduction in the quality of the pasture being offered to early lactation cows and reduced the spring pasture growth rate. It was subsequently recognized that rotation lengths longer than the duration required to produce 3 leaves resulted in no further accumulation of digestible $\mathrm{OM}$ and, in fact, could reduce plant viability and DM production the following spring. This, eventually, led to the recommendation that pasture could be accumulated in situ for grazing during the winter (i.e., the autumn rotation planner), but that the length of the inter-grazing interval should not be longer than the time taken to produce 4 leaves (the extension to 4 leaves was because senescence and the reduction in pasture nutritive value were slowed in winter by low minimum temperatures). As a result, autumn rotations were reduced to between 60 and $100 \mathrm{~d}$, depending on location, and feed quality for early lactation cows was greatly improved.

This research and the resultant understanding of pasture growth profiles led to the development of what is arguably the simplest but most effective decision support resource available for grazing farmers: the spring rotation planner (SRP; Macdonald and Roche, 2016). As pasture growth is significantly less than the 
herd's DM demand during the winter in the majority of places where grazing is practiced, the SRP "rations" the pasture accumulated during the autumn so that winter pasture growth is maximized and cows are well fed through winter and early spring (i.e., from calving to the day that pasture DM growth is equal to the herd's DM demand: referred to by farmers as "balance day" or "magic day"). By using this decision support resource, the pasture remains in the exponential phase of growth for as long as possible without significant loss of OM digestibility and DM production is maximized. The SRP (Figure 3) provides the farmer with the rotation length required through winter and early spring and the amount of land area that can be allocated on any given day during winter and spring. In an important study outlining the system-level benefits of the SRP (Bryant and L'Huillier, 1986), pasture DM production was $1,775 \mathrm{~kg}$ of $\mathrm{DM} /$ ha greater during the first 6 mo of the grazing season when a farm adhered to the SRP during winter than if they had grazed on a faster rotation; this was approximately equivalent to an $18 \%$ increase in DM yield during that period and an $11 \%$ increase in the annual DM yield.

\section{Summary}

In $100 \mathrm{yr}$, research into soil improvement, pasture breeding, and grazing management have moved graz- ing systems from cows being offered low yielding, low digestibility, unimproved pastures with limited grazing infrastructure to highly specialized systems in which cows calve seasonally (i.e., in spring) and graze productive pastures. Instead of free access to large areas of the farm at all times (set-stocking), cows rotate around the farm regularly (i.e., rotational grazing). To allow this, the farm is divided into a network of paddocks, facilitated by the development and refinement of the electric fence, that are interconnected by a series of farm tracks or lanes (see Figure 1). Grazing management has moved from allocating a certain amount of pasture area each day to a better understanding of the needs of the pasture plant and the interaction between the animal and the plant. As a result, systems have evolved to produce $780 \mathrm{~kg}$ of $4 \% \mathrm{FCM}$ and $58 \mathrm{~kg}$ of milk fat and protein from every tonne (DM) of pasture grown (approximately equivalent of $1,000 \mathrm{~kg}$ of $4 \%$ FCM and $74 \mathrm{~kg}$ of fat and protein/t of DM pasture utilized), with virtually no mechanization other than the milking parlor and the electricity required for the electric fence (Macdonald et al., 2008a).

\section{COW FERTILITY}

The success of seasonal grazing systems is dependent on each cow recalving every $365 \mathrm{~d}$, in theory, and the herd calving within a short timeframe (i.e., $\sim 60 \mathrm{~d}$,

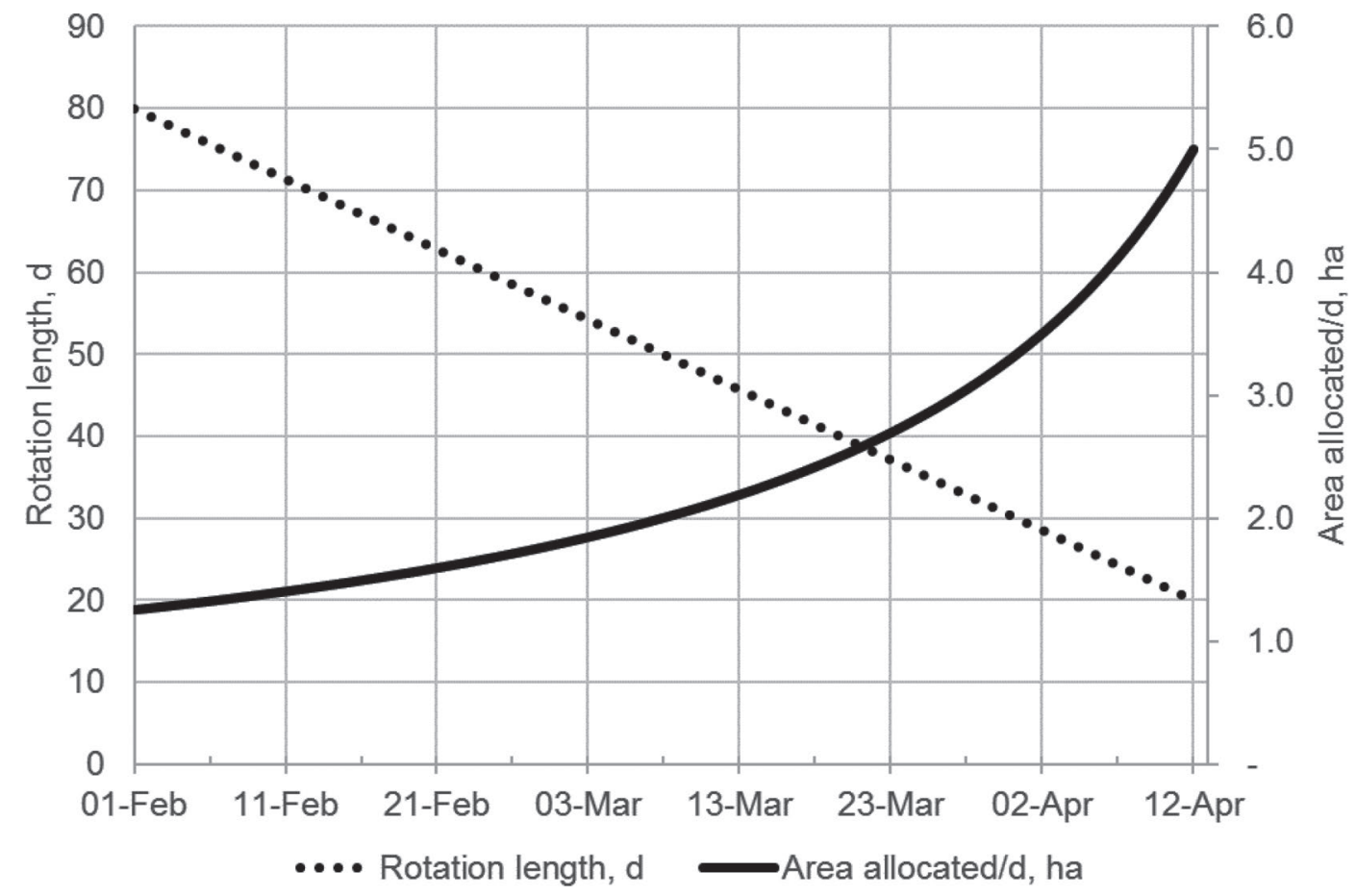

Figure 3. An example of the spring rotation planner for a seasonal-calving, grazing herd. Rotation length (dotted line) declines and the area available to be grazed per day (solid line) increases as the farm progresses through winter and into spring and pasture growth rates increase. 


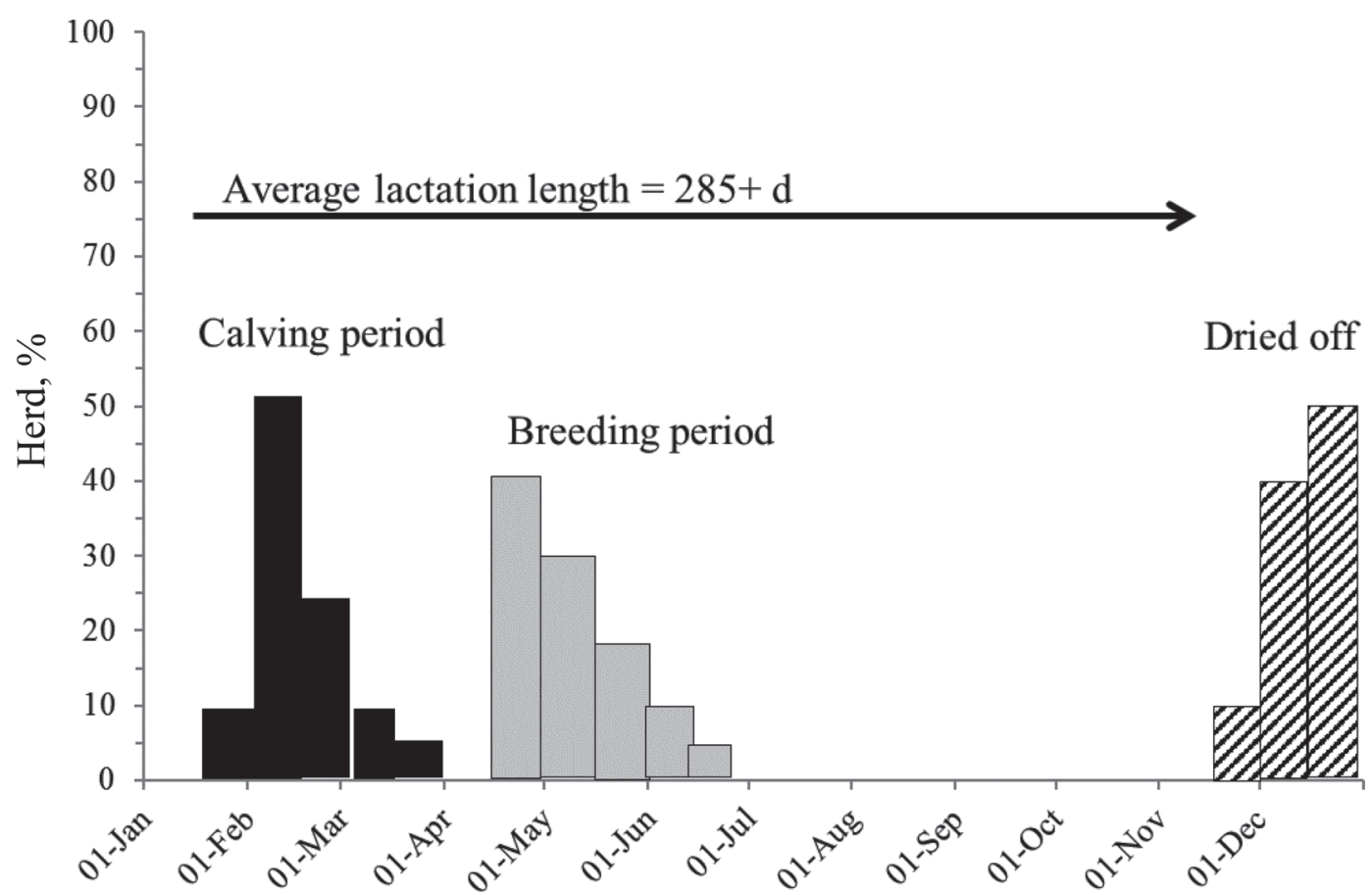

Figure 4. Seasonality of calving, breeding, and drying off (i.e., cease lactation) for cows to ensure the supply and demand curves for pasture are synchronized.

including replacement heifers; Holmes, 1995; Roche et al., 2017b). This logically requires the herd to become pregnant in an equally short timeframe $(\sim 70-80 \mathrm{~d}$, with the difference being the allowance for later calving, cull cows being replaced by heifers). Although this "seasonal peculiarity" in intensive grazing systems is generally accepted, little thought is given to the reproductive technologies that have facilitated the evolution of the large-scale, intensive grazing system. For example, the consequence of a seasonal mating pattern is that a significant amount of semen from the top sires is required during this intensive mating period to satisfy demand.

To ensure success, the planned start of mating must begin approximately $80 \mathrm{~d}$ after the planned start of calving (Figure 4). Cows, therefore, have to return to estrus quickly after calving, be identified by the farmer as being in estrus, and be highly fertile when inseminated, either artificially (AI) or naturally (with a bull). Until the 1930s - when average herd sizes were small and the requirement for bulls was minimal - this was easily manageable. However, the advancement in electric fence technology, milking parlor technologies, and improved pasture management facilitated the shift to large grazing herds. To remain seasonal, however, large herds would have required large numbers of bulls on each farm, with the logistical and safety issues that this would bring. High fertility semen delivered by AI was the answer to this problem, but there were many logis- tical hurdles to clear before this technology could be delivered. Overcoming the difficulties of seasonal breeding on expanding grazing dairy farms was the quandary that faced researchers as they entered the 1940s.

\section{Optimizing Semen Supply}

Liquid Semen Versus Deep Frozen Semen. Grazing systems needed an AI service suited to the unusual requirements of highly seasonal demand (James, 1941). Although deep frozen semen technology was being developed elsewhere, it was not suitable for grazing systems because of the high capital costs associated with medium-term storage for a short period of demand. The early use of AI in research scenarios was very successful (James, 1941), with conception rates (CR) similar to those in achieved natural mating. Low semen dilution rates, short semen shelf life, limited availability of sires of positive genetic merit, and the concentrated peak demand for the insemination service, however, meant that this initial success was not translated into acceptable field results (James, 1946).

The decision was made to develop a room temperature semen extender to reduce the number of sperm cells required per insemination and increase the number of insemination straws from each bull ejaculate. The semen extender was based, initially, on the addition of egg yolk to the Cornell University Extender (CUE; 
Foote, 1970). The initial service used chilled semen with a dose rate of $25 \times 10^{6}$ sperm per insemination deposited in the posterior body of the uterus (instead of deep cervical insemination as practiced elsewhere; Moller et al., 1972). This dose rate had been reduced to $5 \times 10^{6}$ sperm by 1963 through trialing modifications to the CUE, such as adding glycine, glycerol (Shannon, 1964), and caproic acid (Shannon, 1962), as well as saturating the diluent with nitrogen (Shannon, 1965a), and varying the egg yolk concentrations (Shannon and Cursons, 1983). These modifications were necessary to inactivate a toxic heat-labile protein in seminal plasma (Shannon, 1965b) and to neutralize the toxic effect of the hydrogen peroxide produced by an amino acid oxidase released by dead sperm (Shannon and Curson, 1972). The result was a room temperature diluent called Caprogen.

The success of the Caprogen diluent was subsequently demonstrated by achieving high CR relative to the deep frozen semen used in similar systems. Conception rate, measured as the percentage of pregnancies confirmed after insemination, is a key performance indicator of fertility and is usually estimated from the nonreturn rate (NR). The 49-d NR in most of the studies associated with the development of Caprogen have exceeded $60 \%$. This $49-\mathrm{d}$ NR was reported to overestimate final CR by only 2.9 percentage units (66.9 vs. $64.0 \%)$ in 959 cows across 2 field studies involving seasonally calving herds, where each pregnancy was tested to confirm conception (Macmillan et al., 1977b). A subsequent study that included progesterone monitoring reported a CR to AI of $65 \%$ when tail-painting was used as an aid to improve efficiency of estrus detection (Xu et al., 1998). A novel variation involving the use of Caprogen was the development of rediluted deep frozen semen, in which semen was glycerolated before being frozen at a concentration of around $800 \times 10^{6}$ sperm (Shannon and Vishwanath, 1995). It could then be rediluted with Caprogen when thawed before use at a dose of $20 \times$ $10^{6}$ sperm/insemination. When rediluted deep frozen semen at this dose rate was compared with normal "liquid" semen in Caprogen at $2.5 \times 10^{6}$ from the same 11 sires, the 49-d NR were 68.1 and $67.6 \%$, respectively (Shannon and Vishwanath, 1995). In contrast, pregnancy tested cows in seasonally calving herds in Victoria and Tasmania (Australia) that used deep frozen semen and included some herds with DIY inseminating had conception rates of only 49\% (Morton, 2010) and 40\% (Morton et al., 2016).

Sperm Dose Rates. The variations to the CUE diluent mentioned earlier and further developments of the Caprogen diluent between 1958 and 1988 facilitated a $96 \%$ reduction in the sperm required per successful insemination (i.e., from $25 \times 10^{6}$ to $1 \times 10^{6}$ ). This meant that fewer sires were needed to meet the ever-increasing demand for inseminations from an expanding dairy industry and facilitated the expansion in herd size on individual farms. Two additional factors contributed to meeting this demand in New Zealand:

- most herd owners were prepared to accept a nominated bull service, often referred to as "bullof-the-day," rather than selecting semen from specific sires to inseminate specific cows within a herd; and

- the peak in demand for inseminating was accommodated by individuals within the rural community being prepared to accept employment for as little as $6 \mathrm{wk}$ as inseminators, and frequently inseminated over 100 cows in a single day.

This was preferable to individual herd owners practicing "DIY" inseminating, as was occurring in many other dairy industries. The combination of these factors has contributed to the evolution of an AI service particularly suited to the pasture-based seasonal dairying system.

Sexed Semen. Conventional semen contains approximately equal numbers of sperm bearing $\mathrm{X}$ and Y chromosomes; hence, the likelihood of a female or male calf is approximately equal (Roche et al., 2006c). Sexed semen refers to semen that has gone through the process of sorting the $\mathrm{X}$ and $\mathrm{Y}$ chromosome sperm, and most commercially available sexed semen used in the dairy industry contains $\sim 90 \%$ X-bearing sperm. Initially, sexed semen products had markedly inferior fertility compared with conventional semen (Butler et al., 2014), but the gap has closed in recent years with iterative improvements in the sorting technology.

The role for sexed semen in seasonally calving herds has focused on its potential to accelerate herd expansion or to facilitate surplus heifer production for sale, allow shorter periods of dairy semen usage and increase the beef output from the dairy herd, and increase rates of genetic progress (Hutchinson et al., 2013). The best fertility results were obtained when sexed semen was used with well-grown heifers or cows with longer intervals from calving to insemination and better BCS (Butler et al., 2014). Extensive studies in New Zealand herds indicate that doses as low as $1 \times 10^{6}$ sperm per insemination with sexed sperm or normally processed sperm stored in a Caprogen diluent could be used with lactating cows, with the calving rates being only 3 to 4 percentage units lower with sexed sperm (Xu, 2014).

Modeling studies relevant to seasonal-calving, pasture-based systems indicated that the economic returns from the intensive use of sexed semen to accelerate genetic progress were not always positive (Hutchinson 
et al., 2013; Murphy et al., 2015, 2016). This was partly because this pattern of use of sexed semen reduced a herd's ability to maintain a seasonally concentrated calving pattern, through a lower CR in lactating cows (Hutchinson et al., 2013). A follow-up modeling study indicated that targeted usage of sexed semen (i.e., for highest fertility cows only) plus one of either conventional dairy semen, beef semen, or short-gestationlength semen for any cows that returned to estrus was more profitable than use of conventional semen only (Murphy et al., 2015, 2016). Further improvements with diluents used in processing sexed semen to reduce between-sire variation (as happened with the development of room temperature diluents, such as Caprogen) may allow sexed semen to be used without compromising reproductive performance in seasonally calving herds in the future.

\section{Insemination Management on Farm}

Submission Rates and Estrus Detection. Submission rate (SR) is a key performance indicator used in seasonally calving herds to monitor the rate of progress of the insemination program, particularly during the first 3 wk. It was derived initially by recovering calving and insemination data from 97 herds that used AI exclusively for at least $7 \mathrm{wk}$ in the 1971 season to show that herds with a high 4 -wk SR $(>90 \%)$ had the highest herd in-calf rates at 4 and 7 wk, even though they had lower average CR (Macmillan and Watson, 1973). This was because more cows in the high-SR herds had short return intervals through errors in detection preceding first insemination (Macmillan et al., 1977b) and genuine short cycles (Macmillan and Watson, 1971). The use of a 3-wk SR has now become a standard key performance indicator in breeding management programs in seasonal-calving, pasture-based herds.

With increasing herd size came a reduction in rates of estrus detection and in the occurrence of genuine short cycles (Macmillan and Watson, 1973). The solution proved to be the simple and inexpensive technique called "tail-painting" or "chalking" (Macmillan and Curnow, 1977). The technique was adopted widely in grazing systems all over the world and the efficiency and accuracy were subsequently reported as 98.4 and 97.6\%, respectively (Xu et al., 1998).

One consequence of high detection efficiency, however, was that it revealed the extent and severity of anestrus during the postpartum period in many seasonal-calving herds (Fielden and Macmillan, 1973). For example, $85 \%$ of 1,028 primiparous cows that had not been inseminated during the first $4 \mathrm{wk}$ of the seasonalbreeding period and had calved at least 6 wk before the planned start of breeding were diagnosed as hav- ing small "inactive" ovaries (Fielden et al., 1976). The incidence was associated with differences in age, breed, interval from calving date to the first day of AI, and herd size (Macmillan et al., 1975; Macmillan, 2002). The influence of low BCS has also been recognized in subsequent studies (see Roche et al., 2009a). Most studies conducted since 1990 have diagnosed anestrous cows during the month preceding the onset of the seasonalbreeding period, or within the $10 \mathrm{~d}$ after the start of the seasonal-breeding period; using these timing criteria, 20 to $30 \%$ of cows within several multi-herd studies were classified as anestrous (Rhodes et al., 2003; Shephard, 2005 ), and up to $44 \%$ in a recent study in Victorian herds (Plozza et al., 2016). The classification in the early studies of inactive ovaries was subsequently reported to be incorrect. Ovarian follicle waves emerged every 8 to $10 \mathrm{~d}$ from about $10 \mathrm{~d}$ postpartum, but the follicle failed to ovulate (McDougall et al., 1995; Nation et al., 1999).

Estrus Synchronization and Development of the $C I D R$. Although simple single-injection programs that utilize prostaglandin $\mathrm{F}_{2 \alpha}\left(\mathrm{PGF}_{2 \alpha}\right)$ were developed for use in the milking herd (Macmillan et al., 1977a; Macmillan, 2002), these programs had to be used in conjunction with high standards of estrus detection because of the post-injection variation in the interval to estrus (Macmillan and Henderson, 1984). Furthermore, because the $\mathrm{PGF}_{2 \alpha}$ injections were ineffective with anestrous cows (Macmillan et al., 1977a), they failed to address a major problem in seasonal-calving herds. Although the effectiveness of whole-herd synchronization programs has been demonstrated under grazing conditions, they have not been widely adopted. This is, at least in part, because the resulting concentration in calvings can overwhelm limited labor and feed resources.

The greatest changes in the application of synchronization in seasonally calving herds followed the development of the controlled internal drug-releasing (CIDR) insert for the vaginal administration of progesterone for periods of 5 to $14 \mathrm{~d}$ in dairy cows and heifers that were anestrous (Macmillan and Peterson, 1993). The insert has been used in combinations with injected $\mathrm{PGF}_{2 \alpha}$, $\mathrm{GnRH}$, and estradiol benzoate. Its use has become the standard treatment for anestrous cows in seasonally bred dairy herds.

\section{Reproductive Management of the Herd- Getting Cows in Calf}

Recent industry investment in intensive monitoring programs has produced standardized sets of management recommendations in combination with publications for use by herd owners, advisers, and veterinar- 
ians. The first of 2 Australian studies (Morton, 2010) derived records for a single season from 124 seasonally calving herds containing over 31,000 cows. The second study was a longitudinal study with records derived from 74 herds during the period from 2000 to 2009, covering 481 mating periods and reproductive data for over 100,000 cows (Morton et al., 2016). The results in both studies measured the effects of a wide range of factors that influenced 2 primary performance indicators (6-wk in-calf rate and 21-wk not-in-calf rate) at the herd and cow levels, as well as 2 secondary performance indicators (3-wk submission rate and confirmed CR to first insemination; Morton, 2010). The 2 primary indicators were identified as being the critical outcomes for a breeding program in a seasonal-calving herd, whereas the secondary indicators were the key drivers to achieve any goals set for the primary indicators. A similar study based on records from over 100,000 cows was conducted in New Zealand (Xu and Burton, 2003) except that the 21-wk period was reduced to 12 -wk not-in-calf rate to reflect the more intensive breeding policy in a strict seasonal-calving system. None of the studies included calving interval, which is a key indicator of reproductive performance in herds where cows calve throughout most of the year but is of limited relevance to seasonalcalving systems because it cannot be allowed to vary beyond $365 \mathrm{~d}$.

\section{Summary}

Although the complexities of seasonal breeding are often acknowledged, the need for a service that could provide sufficient volumes of semen from high-geneticmerit bulls for AI is often understated. The pivotal work of Pat Shannon and his team in developing diluents that allowed a $96 \%$ reduction in the quantity of sperm per insemination and the extended viability of "fresh" semen facilitated the increased scale of grazing farms while maintaining the seasonality of calving in-line with pasture supply. The simple technology of tail-painting facilitated accurate estrus detection in large herds and high submission rates of cows for AI. Synchronization program developments, other than the use of CIDRs to kick-start estrus in anestrous cows, have largely been ignored, most likely because of the pressure they put on a limited labor force at calving and the limited feed resources that are available in grazing systems at the onset of a seasonal calving period (i.e., winter). The development of the CIDR, however, facilitated the breeding of cows that have a delayed return to estrus after calving and increased the likelihood of pregnancy within the defined breeding period. Significant industry investment has resulted in a successful extension effort that helps farmers identify the metrics of reproductive failure (and success) on their farm and provides potential solutions to overcome the managerial failings.

\section{COW BREEDING FOR GRAZING SYSTEMS}

An old Irish adage states, "an ounce of breeding is worth a pound of feeding," implying that animal quality and performance is born, not made. This is consistent with McMeekan's principle for running a successful grazing system: "use animals that will process the grass efficiently" (McMeekan, 1960). Although milk recording services became available in many countries at the beginning of the 20th century, most "dairy cattle" possessed dual-purpose characteristics in 1917 to supply both replacement female calves for milk production and bull calves with good beef characteristics. This was identified as "the one factor wherein the charge that farmers are careless in business was justified" (Anonymous, 1924); for example, just before the report cited, $50 \%$ of champion milk producers in New Zealand had been purchased for a fraction of their value because the previous owner had no knowledge of the yields of individuals within his herd (Anonymous, 1924).

In the early 20th century, farmers were encouraged to "milk record" to identify the "top-notch" and "boarder" cows (the term "boarder" was used for a cow that boarded but provided very little value in their herd; Anonymous, 1924). Following World War I, the numbers of farmers using herd recording services and the number of cows recorded globally greatly increased: for example, in the UK, in 1917, 478 farmers recorded 13,838 cows; by 1938 , this had increased about 10 -fold to 4,302 farmers recording 161,077 cows (Atkins, 2016). In comparison, in New Zealand, $5 \%$ of cows were being milk recorded in 1917, increasing to approximately $25 \%$ in 1950 and to a peak of almost $90 \%$ of all cows in the country, or 3 million cows, in 2005. Milk recording was a producer-driven initiative in the early years and became an official, national scheme in 1936 in New Zealand and in 1943 in the UK (Atkins, 2016). Milk recording in Ireland began in the 1940s but was undertaken only on herdbook-registered cows. Cows were milked using bucket plants and the milk of each cow was weighed. The first "milk recording jars" appeared in Ireland in the 1950s, facilitating the determination of yields from the graduated scale on the jars; mechanical milk meters were introduced in the 1960s and electronic "do-it-yourself" milk meters (Berry et al., 2006) in the early 2000s. With the increased ease of milk recording/ herd testing, the proportion of the Irish herds being milk recorded increased from approximately $10 \%$ of the national herd in 1991 to $51 \%$ in 2016.

By 1917, herdbook societies had been in operation for approximately 100 yr (Brotherstone and Goddard, 
2005), but their focus on improving dairy characteristics was limited because of the concurrent breeding for beef-related traits. The Shorthorn breed had risen to prominence because of its milk yield and "butchering potential." In fact, herds of Shorthorn cattle were identified in every area of England "where milk production was an important part of the agricultural economy," whereas the Ayrshire remained the dairy breed of choice in Scotland (Atkins, 2016). Similarly, in New Zealand, the Shorthorn was the most popular dairy breed in 1920 ( $~ 50 \%$ of cows), followed by the Jersey breed ( $\sim 30 \%$ of cows). Although relatively rare on dairy farms ( $\leq 10 \%$ of cows), Holstein cows were popular among urban "cow-keepers" in the early part of the 20th century (Atkins, 2016). Through the concerted efforts of the Friesian and Jersey herdbook societies, these breeds rapidly overtook the Shorthorn breed in popularity. In the UK, the British-Friesian increased to $20 \%$ of cows in 1947 and $76 \%$ in 1970 , whereas the Shorthorn fell from 85\% in 1908 to 3\% in 1970; this breed change was mirrored in Ireland. In New Zealand, because of the focus on dairy product export, the Jersey breed replaced the Shorthorn; between 1921 and 1949, the Jersey increased from $30 \%$ to $86 \%$ of the national herd and the Shorthorn decreased from $50 \%$ to $<5 \%$.

The development of the BLUP methodology for genetic evaluations (Henderson, 1950) heralded a new era of genetic evaluation, providing a framework that easily ranked animals on traits of importance. Grazing systems until the late 1900s operated similar breeding objectives to most other countries, focusing on yield of milk or yield of milk constituents. In New Zealand, a national breeding objective that included just fat yield was introduced in 1953 and genetic evaluations of sires were published annually. Genetic progress was accelerated with the widespread adoption of AI technologies from 1950. Breeding strategies for increased milk yield in intensive feeding and housed systems in North America and Europe and a reasonably lucrative dairy beef market for Friesian bulls resulted in greater use of Holstein-Friesian semen, initially imported from North America and later from Europe during the 1970s and 1980s (Harris and Kolver, 2001). Furthermore, the relative price of whole and skim milk powder over butter and cheese, which were declining in popularity due to simplistic and, ultimately, inaccurate health messages, led to an increased economic weighting on milk protein over fat and a further shift from Jerseys to the Holstein-Friesian breed through the 1990s.

The rate of adoption in grazing systems of germplasm identified from nongrazing systems was exceptionally high toward the end of the 20th century. For example, Harris and Kolver (2001) reported that the percentage of North American/Dutch Holstein-Friesian genetics in sires used for AI in New Zealand increased from $22 \%$ in 1980 to $>70 \%$ in 1999. As a result, from 1980 to 1999, the average percentage of North American/Dutch Holstein-Friesian in the New Zealand dairy cow population increased from 2 to $38 \%$, and the percentage of Holstein-Friesian cows with some North American/ Dutch Holstein-Friesian increased from 7 to $96 \%$. By the mid-1990s, the breed structure of the New Zealand national herd was 57\% Holstein-Friesian, $16 \%$ Jersey, $18 \%$ Holstein-Friesian $\times$ Jersey crossbred, $2 \%$ Ayrshire, and $7 \%$ other dairy breeds and their crosses. This was a large change from a national herd of $30 \%$ purebred Jersey, 11\% Holstein-Friesian, and 50\% Shorthorn in 1921. A similar holsteinization phenomenon occurred in Ireland; a retrospective analysis reported that the proportion of North American Holstein-Friesian genetics increased from 8\% in 1990 to $63 \%$ in 2001 (Evans et al., 2006).

In the 1990s, selection indices were further developed to incorporate more traits of economic importance. For example, the national breeding objective in Ireland at the time (i.e., Relative Breeding Index) was expanded to include milk component traits as well as volume, whereas that in New Zealand (i.e., Breeding Worth) was expanded to include positive weightings for protein as well as fat, a negative weighting on cow body weight, and an economic measure of the lifetime value of a cow relative to a set annual DMI (as a proxy for feed conversion efficiency; Harris, 1995). At the same time, New Zealand moved from a within-breed evaluation index to a single genetic evaluation across all breeds. These changes heralded the first signs of the multi-breed and multi-trait genetic evaluation systems and indices that were to follow.

The evolution of the "specialist grazing cow" began in earnest during the 2000s. In the 1990s, producers reported concerns that the modern Holstein-Friesian cow had inferior fertility compared with her predecessor. Much of those protestations were ignored because it was largely thought that breeding for or against fertility traits was not possible due to its low heritability. Numerous experiments were undertaken in New Zealand (Kolver et al., 2002; Roche et al., 2006b; Macdonald et al., 2008b), Australia (Fulkerson et al., 2008, 2001), and Ireland (Buckley et al., 2000; Kennedy et al., 2002; Horan et al., 2005a) to determine whether different genetic strains performed differently under different feeding systems (i.e., genotype $\times$ environment interaction). Although there was evidence that feeding regimen influenced the marginal milk production response to nonpasture feed and the ability of the dairy cow to exhibit her genetic potential compared with her peers (Kennedy et al., 2002; Fulkerson et al., 2008), the greatest differences between the strains were in the 
extent of negative energy balance in early lactation (Buckley et al., 2000; Roche et al., 2006b) and in their pregnancy rates in a seasonal calving system (Horan et al., 2005c; Macdonald et al., 2008b), irrespective of feeding regimen. In brief, 6 -wk in-calf rate in North American-derived Holstein-Friesian cows was 15 percentage points lower than that of New Zealand-derived Holstein-Friesian cows (Horan et al., 2005c; Macdonald et al., 2008b) and they were less likely to survive to successive lactations (Harris and Kolver, 2001). Subsequent research concluded that the lower pregnancy rates in the North American-derived Holstein-Friesian was a result of early embryo loss 2 wk after conception and that at least some of this difference may be epigenetically regulated (Walker et al., 2012, 2013).

As evidence accumulated in seasonal-calving grazing systems of the inferior reproductive performance and survival of Holstein-Friesian strains selected in nonseasonal breeding systems, breeding objectives evolved rapidly. In 2001, the Economic Breeding Index (EBI) was introduced in Ireland and included calving interval and survival, in addition to the milk yield traits already included in the Relative Breeding Index. Similarly, fertility was included in the New Zealand national breeding goal in 2002. By 2017, the EBI included 18 traits encompassed within 7 sub-indices: (1) milk production, (2) fertility and survival, (3) calving performance, (4) maintenance, (5) beef performance, (6) health, and (7) management. The evolution of the EBI since 2001 is illustrated in Figure 5, and the impact of this breeding objective on genetic trends for milk solids production and fertility is in Figure 6.

Recognition of the success of this multi-trait approach in designing the ideal cow for seasonal calving and grazing systems has led to the development of the US Grazing Merit Index (GM\$; Gay et al., 2014) and the UK Seasonal Calving Index in 2014, with both indices putting increased emphasis on functional traits associated with grazing and the need to achieve pregnancy within $80 \mathrm{~d}$ of calving. The seminal paper on genome wide-enabled selection by Meuwissen et al. (2001), coupled with the commercial availability of lowcost, high-density genotype panels, revolutionized dairy cow breeding programs in the early part of the 21st century, including in countries like Ireland and New Zealand, the impact of which is described in Spelman et al. (2013).

\section{Summary}

The predominant breed in grazing systems shifted from Shorthorn and Jersey to Holstein-Friesian between 1917 and 2017, but there has been a shift away from breed preference in the 21st century because of acrossbreed genetic evaluation systems and a single breedagnostic breeding objective. The multi-trait breeding goals for seasonal calving and grazing animals have been very successful in pursuing the optimum cow for grazing systems and, with developments in phenotyping tools and strategies, as well as advances in "-omics" technologies, we expect that grazing cows will be more fertile, longer lived, resilient to changes in feed availability and quality, and produce large yields of fat and protein relative to BW and annual DMI.

\section{NUTRITION RESEARCH IN GRAZING SYSTEMS}

At the World Dairy Congress in 1928, Robert Boutflour from Harper-Adams College (Shropshire, UK) identified 4 factors that, in his opinion, were the most

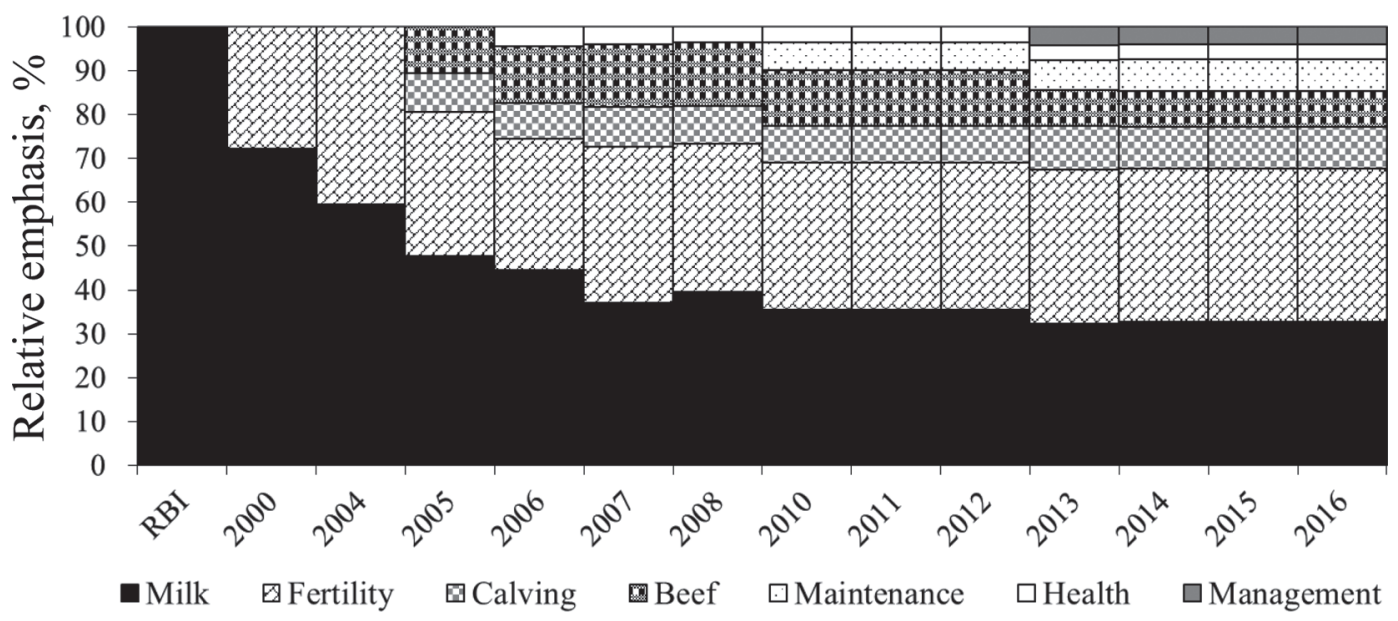

Figure 5. The evolution of the Economic Breeding Index, a multi-trait breeding objective in Ireland that includes traits other than production that are important to profitability. RBI $=$ Relative Breeding Index. 


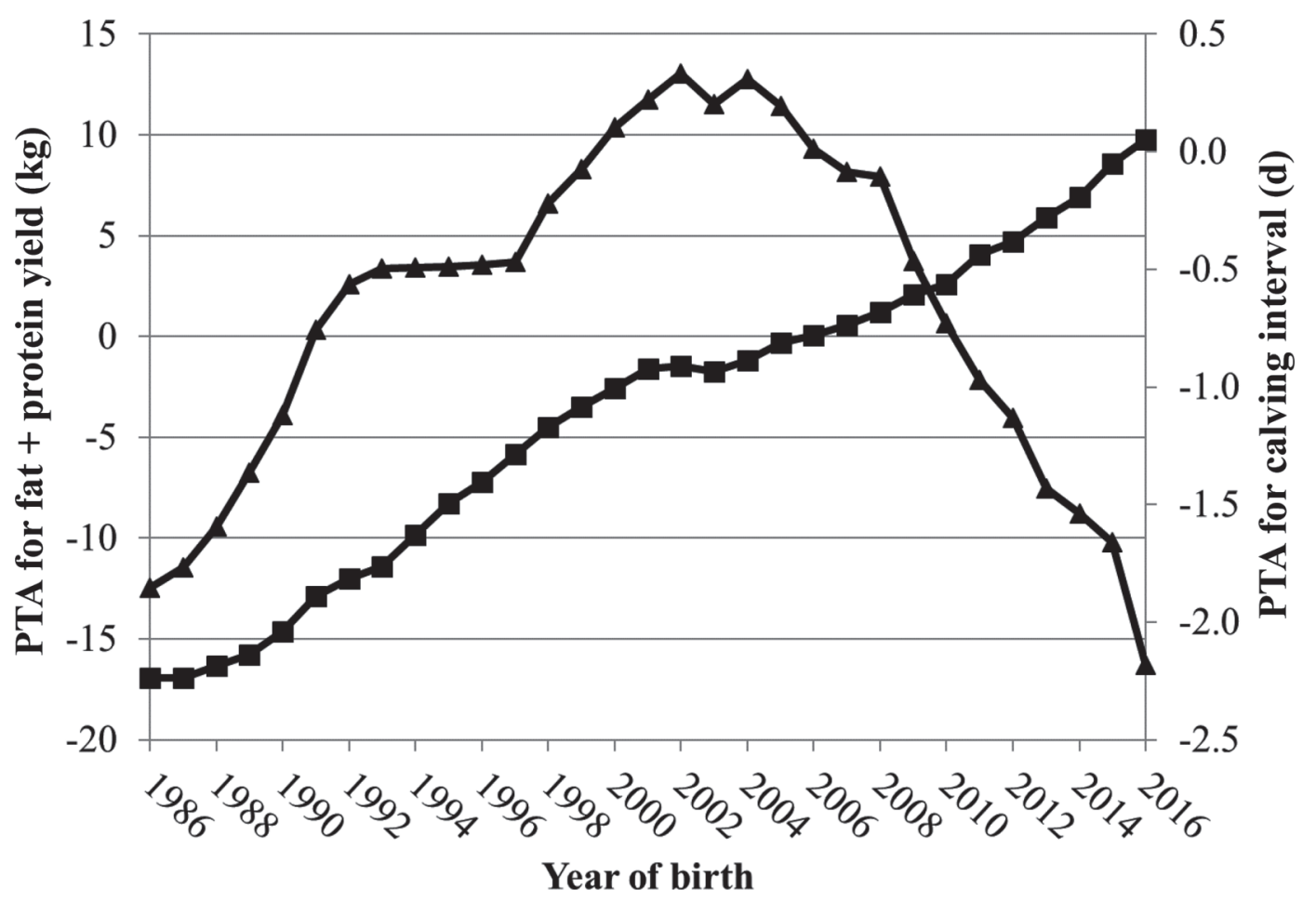

Figure 6. The effect of introducing the Economic Breed Index in 2001 on genetic trends for milk fat and protein production (ם) and calving interval, as a measure of fertility $(\mathbf{\Lambda})$. Despite the reduced weighting on milk production and an increased weighting on fertility, the genetic trends for increased milk production did not diminish.

limiting for milk production: (1) "lack of control of indigestible fiber"; (2) "lack of control of the total amount fed"; (3) "the neglect of the preparation of the cow for her lactation period"; and (4) "the over-stocking of the udder." The first 3 referred to dairy cow nutrition. At the time, cows grazed unimproved pastures and were supplemented with "undecorticated cotton cakes and inferior fodders" (Boutflour, 1928). Boutflour recommended that cows should be "steamed up" before calving, offered only a limited amount of crude fiber, and the forage-to-concentrate ratio should be reduced gradually through early lactation, always ensuring that the cow is "fed for one gallon more milk than she is giving" (i.e., individually fed relative to her milk yield). The requirements of close-up transition dairy cows, the need to maximize DMI, the requirement for individualized feeding of supplementary feeds, advantages of concentrate feeds over pasture, and potential advantages for individualized feeding of grazing dairy cows have been the subject of nutrition research for the last 100 yr.

\section{Transition Cow Nutrition}

Pasture-grazed transition dairy cows have very little dietary adjustment to undertake and, for the most part, the diet is well balanced, with the exception of some minerals. Protein quantity and quality is adequate and there is little need to adapt cows to their postcalving diet, as the transition from pasture and silage to pasture is benign. The focus of transition cow nutrition, therefore, has been on energy nutrition and the prevention of metabolic diseases.

Energy Nutrition. Boutflour (1928) introduced the term "steaming up" cows before calving, wherein he attacked the prevailing wisdom that the way to avoid milk fever was to underfeed cows in the weeks preceding calving. He recommended that the cow's DMI be stepped up during the $6 \mathrm{wk}$ before calving and "in the last fortnight before calving a sufficient quantity be given to thoroughly prime the cow." The effect of precalving feeding level was evaluated in grazing cows in the 1940s (Lees et al., 1948) and 1960s (Hutton and Parker, 1973) over multiple seasons; both reported benefits to greater DMI before calving compared with feed-restricted cows. However, in both of these experimental programs, the difference in precalving DMI was extreme and for extended periods. For example, the feeding treatments imposed during the nonlactating period by Lees et al. (1948) resulted in a $57-\mathrm{kg}$ difference in BW between treatments. Considering the expected difference in BCS associated with such extremes in feeding, it is hardly 
surprising that the high plane of nutrition resulted in 12 to $29 \mathrm{~kg}$ more milk fat/cow and that they were easier to get in calf. It is noteworthy, however, that the incidences of milk fever and grass staggers (i.e., hypomagnesemia) were also greater in this group. Hutton and Parker (1973) similarly compared extreme feeding treatments before calving; their treatments resulted in a difference of $0.7 \mathrm{~kg}$ of $\mathrm{BW}$ gain/d during the final 4 wk before calving. The high plane of nutrition resulted in a 15 to $21 \%$ increase in milk fat yield during the first 8 wk of lactation. Despite the extremes in feeding level and the lack of information on cow BCS, these studies served to support the recommendation of Boutflour (1928) that cows needed to be steamed up before calving. In situations where cows were fed only conserved silage during the winter months, the same problem can arise, because silage quality is often inadequate to meet the cow's precalving requirements for energy and sometimes, protein; as a result, increased feed allowance and even concentrate supplementation of precalving cows is sometimes recommended (Keady et al., 2001).

Such a recommendation can be problematic in a seasonal-calving grazing system, because pasture growth is less than herd demand and, as a result, pasture availability is scarce, and cows are often a distance from equipment used for feeding. In trying to define the optimum precalving feeding level for grazing cows, Roche et al. (2005) reported an interesting finding: there was no difference in milk production between herds of cows offered 75,100 , or $125 \%$ of daily ME requirements during the month before calving, and a $50 \%$ restriction only marginally reduced milk production (4 $\mathrm{kg}$ of fat and protein). Furthermore, BW and blood metabolic profiles indicated that the severity of the postpartum negative energy balance increased with precalving feeding level and that the risk of hypocalcemia increased. Further research confirmed these findings (Roche, 2007). Roche et al. (2015) hypothesized that the discrepancy between the historical and recent studies may relate to calving BCS, because formalized systems to define calving BCS were not available until the 1970s and 1980s (Lowman et al., 1976; Mulvany, 1977; Wildman et al., 1982; Robins et al., 2002; Macdonald and Roche, 2004). Roche et al. (2009a) had previously defined the optimum calving BCS for production, health, and reproduction. Consistent with the hypothesis, Roche et al. (2015) reported an interaction between precalving BCS and precalving feeding level such that optimally conditioned cows benefitted from a 10 to $20 \%$ restriction in ME intake during the month before calving, but thinner cows did not. Further research (Roche et al., 2017a) by this group also noted that restricting cows to less than $65 \%$ of $\mathrm{ME}$ requirements resulted in an exacerbation of the peripartum chronic inflammation and reduced milk production. Therefore, the difference between historical recommendations and those reported recently would appear to relate to the degree of precalving restriction and the BCS state of the cows undergoing the feeding level treatments. Nevertheless, in all cases, increased precalving DMI was associated with a greater risk of milk fever at calving.

Preventing Metabolic Diseases. Although grazing cows can be hyperketonemic, this is primarily of ruminal origin if the cows are not over-conditioned (Roche et al., 2013). The primary metabolic disease affecting grazing cows is hypocalcemia and its clinical manifestation, milk fever. Milk fever was a very serious issue in pasture-based systems until the 1970s (Roche and Berry, 2006), at which point the introduction of precalving magnesium supplementation greatly reduced the risk. However, although prevalence is low in pasturebased systems, up to $30 \%$ of cows on some farms can still be affected. Therefore, solutions are always being sought by farmers with problems. Altering the DCAD before calving has been a very successful strategy for preventing milk fever in TMR systems (Goff and Horst, 1997), wherein the base DCAD is low $(\sim 20 \mathrm{mEq} / 100$ $\mathrm{g}$ of DM) and the diet can be tightly controlled. When evaluated in pasture-fed cows (Roche et al., 2003a,b, 2007a), the acid-base biochemistry and the increase in urinary calcium output were similar to those reported in TMR-fed cows. However, to achieve these biochemical changes, DCAD had to be $<0 \mathrm{mEq} / 100 \mathrm{~g}$ of DM (Roche et al., 2003b), and this was a practical problem. In grazing systems, the base DCAD can be 2 to 3 times that reported in TMR systems (Roche et al., 2000) and there is no way to determine the DCAD selected by the cow in the paddock. Therefore, if DCAD were to be used in grazing systems, DMI of pasture would have to be minimized and the cows fed a mixture of low-DCAD feed ingredients and anionic salts. The increased capital requirements for feeding, not to mention the need for non-pasture-based feeds, would unduly complicate the feeding regimen and feeding infrastructure of grazing dairy systems. Although biochemically effective, the DCAD concept has been, essentially, branded impractical for the prevention of milk fever in grazing systems.

Classical milk fever occurs within $24 \mathrm{~h}$ of calving (Roche and Berry, 2006) when the drain of blood calcium for colostrogenesis is not replenished sufficiently. The incidence of milk fever-related recumbent cows was estimated at $>10 \%$ in pasture-based systems until the late 1970s (Roche and Berry, 2006), but, by 2001, the incidence had declined to $\sim 1 \%$ in a survey of commercial farms (McDougall, 2001). Even with prepartum magnesium supplementation, however, milk fever incidence on individual farms could still affect $\sim 30 \%$ of cows. In general, the problem was solved with the 
additional supplementation of finely ground limestone (i.e., calcium carbonate) to cows at each of the first 4 milkings after calving (Roche et al., 2003a). Pragmatic ways to supplement grazing cows were developed by farmers; pasture was "dusted" with magnesium oxide pre- and postpartum and with calcium carbonate in the fresh cow paddock (i.e., the first $4 \mathrm{~d}$ after calving). This combination has proved to be a very effective control strategy for milk fever.

Despite these effective control strategies for classical milk fever, a non-classical milk fever became apparent in the 2000s and was associated with over-conditioning and, in many cases, low blood P. Most of the temperate grazing systems are located $>35^{\circ} \mathrm{N}$ or $>35^{\circ} \mathrm{S}$, which means that very little vitamin $\mathrm{D}$ is produced naturally. This means that very low phosphorus diets result in a rapid decline in blood $\mathrm{P}$, which can result in a complicated form of milk fever. Its incidence is generally in systems grazing root crops that are low in $\mathrm{P}$, and it is often associated with over-conditioning and excessive energy intake before calving. Precalving supplementation with dicalcium phosphate and an energy-restricted diet in the weeks preceding calving has addressed the majority of non-classical milk fever, although oral vitamin D supplementation is necessary in certain situations (Goff, 2006).

In summary, the incidence of periparturient health disorders in grazing systems is low (McDougall, 2001) and, over the last $50 \mathrm{yr}$ in particular, an awareness of the primary factors involved has led to almost irreducible levels at a national level. Most control strategies involve magnesium supplementation from several weeks before calving (Roche et al., 2002; Roche and Berry, 2006) and calcium supplementation immediately after calving (Roche et al., 2003a), although a minor precalving energy restriction as well as phosphorus and vitamin D supplementation can aid prevention in stubborn cases. For the most part, sufficient manipulation of DCAD for milk fever control is impractical.

\section{Lactating Cow Nutrition}

Over the 100 yr considered in this review, research in the nutrition of grazing dairy cows has focused on maximizing milk production per cow by identifying the factor most limiting production. In recent decades, however, the system-level implications of providing supplementary feeds on the milk production of the herd and the cost of this marginal milk produced have been a considerable focus of investigation.

Although Boutflour (1928) recommended a reduction in forage-to-concentrate ratio through early lactation to ensure that the total bulk of the ration did not limit intake, he was referring to poorly digestible fiber sources, such as "undecorticated cotton cakes and inferior fodder sources." It was acknowledged early in the period considered that, in terms of nutrition, pasture could support a reasonable level of milk production. Woodward (1936) noted that the quantity of digestible protein and $\mathrm{P}$ consumed by the cows was consistently in excess of requirements for the projected milk production and that Ca intake was twice $\mathrm{P}$ intake. He concluded that immature pasture was a relatively well-balanced feed, provided DMI was sufficient for the milk produced: "if a cow will eat enough immature grass to provide the required digestible nutrients and if this grass has a normal content of minerals, her ration is not likely to be deficient in any of the essential food constituents." He concluded that the reason for the mid-season decline in milk production was a lack of feed, not a reduction in the quality of the feed on offer. These figures were in agreement with Melville and Sears (1941), who developed a novel approach to measuring digestibility in grazing animals.

The fact that grazing cows have to "work" more to acquire their feed than housed cows and that this limits their DMI has been well established. In pivotal work to understand the amount of pasture a cow could graze and the likely milk production expected from their pasture DMI, Woodward (1936) reported that cows producing $\leq 1 \mathrm{lb}(0.45 \mathrm{~kg})$ of milk fat could "maintain their production and BW in the spring as well without grain feeding as with grain feeding," suggesting that there was a threshold level of milk production above which grazing cows would produce more milk if supplemented with concentrate feeds. Furthermore, he deduced from feeding experiments that cows could consume enough cut pasture to maintain a milk production of $37 \mathrm{lb} / \mathrm{d}$ $(17 \mathrm{~kg} / \mathrm{d})$, but DMI was often substantially less than this maximum when cows had to graze. Although not expressed specifically, the results imply an interaction between pasture mass, sward structure, and pasture DMI. When pasture was optimally presented, cows could graze $34 \mathrm{lb}(15 \mathrm{~kg})$ of DM/d of $69 \%$ DM digestibility pasture during mid lactation.

Within a grazing system, however, pasture is not always optimally presented. For example, Cooper (1941) highlighted that peak milk production occurred later in grazing cows than it should, from a physiological standpoint; instead, it coincided with the peak in pasture growth. Therefore, milk production was less because of inadequate availability and feed quality of pasture during early lactation. He also noted that the postpeak decline was not a constant, because of greater variability in both pasture supply and quality during late spring and summer. These limitations of the pasture-based system are identified as a reason to provide cows with non-pasture feeds (i.e., supplementary feeds) 
to improve milk production/cow; however, McMeekan (1947) advised that this marginal milk is unlikely to be economic for the dairy farmer.

By the 1940s, evidence had amassed that pasture could sustain reasonable amounts of milk production per cow but that concentrate feeding would increase milk production beyond that achievable on an allpasture diet. Nevertheless, the perception that pasture was not a well-balanced feed persisted. McMeekan (1947) stated, "from the qualitative angle, it is often assumed and frequently stated that pasture is not capable of supplying the needs of a high producing dairy cow and ideally needs to be supplemented with suitable concentrates." Lancaster (1947) reported on 85 digestibility trials on improved and unimproved temperate pastures and tropical pastures in different regions in New Zealand; OM digestibility in the improved pastures in spring was 78 to $82 \%$. When tropical grasses became dominant, summer OM digestibility declined to $65 \%$, but autumn OM digestibility returned to $80 \%$. Unimproved pastures had OM digestibilities between 73 and $80 \%$. McMeekan (1947) used examples of herds averaging 180 to $230 \mathrm{~kg}$ of milk fat/cow per lactation and lifetime production records of almost $2,300 \mathrm{~kg}$ of fat/cow on unsupplemented pasture as proof that well-managed rotationally grazed pastures were a high quality feed. In the succeeding decades, better grazing management strategies resulted in the presentation of more vegetative and digestible swards.

Many experiments confirmed the high feed quality of these vegetative pastures (see Roche, 2017) and highlighted that any improvement in milk production from supplementing grazing dairy cows with supplementary feeds could be explained by the increased intake of ME and not a change in any other nutritional factor (Carruthers et al., 1997; Roche et al., 2010; Higgs et al., 2013). In fact, in an extreme example, Kolver and Muller (1998) transferred housed cows consuming TMR onto pastures dominated by perennial ryegrass-white clover; milk production declined almost $20 \%$. However, $90 \%$ of the difference in milk production could be explained by DMI, energy expenditure in grazing, and the greater $\mathrm{NE}_{\mathrm{L}}$ in milk from grazed cows because of higher milk component percentages; this was without factoring any difference between the ME content of the pasture and the TMR. Collectively, the experimental results provide no argument for substituting another feed for grazed pasture (Roche, 2017). Nevertheless, despite compelling evidence to the contrary, many advisors still believe that there are nutritional advantages to providing cows with sources of NSC, in particular, and even sources of undegradable dietary protein when milk production is not limited by a deficiency of MP or a particular amino acid (Roche, 2017).

\section{Responses to Supplementary Feeds}

In the early 1940s, average milk production/cow was equivalent in New Zealand, the United Kingdom, and the United States (Cunningham, 1942). But after World War II, a divergence in production philosophy between systems predominantly based on grazed pasture and those increasingly using cut forages and concentrate feeds became evident. The latter became focused on ensuring the cow was maximally fed, whereas there was a recognition in grazing research that to optimize the utilization of pasture, there may be a "possible cost to the animal" (Melville and Sears, 1941; Mott, 1960). Hamilton (1942) credited the ability of grazing systems to rely almost exclusively on pasture to the development of refrigeration, which has allowed seasonal production of milk; he acknowledged, "the season curve of dairy production follows very closely the curve of pasture production." However, like Cooper (1941), he also acknowledged that milk production was compromised by a lack of available feed during summer and autumn.

The recognition that milk production was compromised by a lack of pasture availability at key times of the year resulted in considerable research efforts into investigating milk production responses to supplementary feeds in grazing systems. Hamilton (1942) referred to the adage that "half the breeding goes down the throat" and noted that high production/cow can only be achieved "when nutrition is kept on a uniform high plane throughout the year." He claimed that the $36 \%$ improvement in milk fat production between 1916 and 1940 (79 to $108 \mathrm{~kg}$ of milk fat) was a result of the shift to the Jersey breed, superior pasture management, and the increased conservation of hay and silage (the area conserved as silage or hay had increased $400 \%$ between 1920 and 1940), acknowledging that farmers were focused on the provision of feed for periods when pasture growth was less than herd demand. In fact, he reported that there was a close relationship between the area saved for hay and silage and production per cow the following season. He also estimated that the amount of hay and silage conserved could be easily doubled. In summary, Hamilton (1942) identified that although vegetative temperate pastures were a well-balanced feed, there were periods of the year where reduced supply compromised milk production, and supplementary feeds could help overcome the deficits and increase milk production/cow.

In addition to the lack of pasture availability, in many situations, it was also expected that the physical bulk of forages and the limited capacity of the ruminant gastrointestinal tract were dominant factors limiting pasture DMI (Boutflour, 1928; Ellis, 1978) and that the provision of a source of highly digestible concentrated 
fiber (e.g., sugar beet pulp) or NSC (e.g., corn grain) would increase energy intake by the amount of energy contained in the concentrate. In theory, therefore, $1 \mathrm{~kg}$ (DM) of concentrate should result in approximately 2 $\mathrm{kg}$ of milk because of the energy contained. In practice, however, the mean response to concentrate supplementation is much less. The discrepancy between theoretical and actual marginal milk production responses is due to (1) a reduction in pasture intake (i.e., substitution) when supplementary feeds are consumed (Leaver, 1985; Stockdale, 2000; Bargo et al., 2003); and (2) a proportion of the consumed energy being partitioned to BCS (Roche et al., 2009a).

Evaluation of concentrate supplementation in grazing systems is reported as far back as the early 1940s (Riddet and Campbell, 1943). Several reviews outline a change in milk production responses to concentrates over time (Journet and Demarquilly, 1979; Gleeson, 1984; Leaver, 1985; Stockdale, 2000; Bargo et al., 2003). Leaver (1985) reported that marginal milk production responses to concentrates in the 1950s and 1960s were $0.4 \mathrm{~kg}$ of milk/ $\mathrm{kg}$ of concentrates. This response is consistent with the response reported by Journet and Demarquilly (1979), and Gleeson (1984) reported similar responses to molasses offered during autumn $(0.3 \mathrm{~kg}$ of milk $/ \mathrm{kg}$ of molasses) but no additional milk production to either molasses or barley when cows had an adequate pasture allowance in spring. Stakelum et al. (1988) reported average responses of $0.5 \mathrm{~kg}$ of milk $/ \mathrm{kg}$ of concentrates from a series of experiments undertaken in the early 1980s. However, this response varied from 0.13 to 0.98 and was almost always higher in autumn than in spring. The effect of season on the marginal milk production response to concentrates is well documented (Stockdale, 2000). Reviews by Stockdale (2000) and Bargo et al. (2003) indicate that the response to concentrates increased to $1 \mathrm{~kg}$ of milk $/ \mathrm{kg}$ of DM concentrates (i.e., $0.9 \mathrm{~kg}$ of milk $/ \mathrm{kg}$ of concentrates) during the intervening years, and Horan et al. (2005b) and Roche et al. (2013) reported that total responses were 1.1 to $1.2 \mathrm{~kg}$ of milk/ $/ \mathrm{kg}$ of concentrate DM (or $1 \mathrm{~kg}$ of milk/ $\mathrm{kg}$ of concentrate). The results indicate that responses to supplements have increased over a half-century of intensive investigation. This is because genetic selection priorities for milk production haves reduced the substitution rate and increased the partitioning of energy directly to milk at the expense of BCS.

The phenomenon whereby cows refuse some pasture following the consumption of an alternative feed is referred to as "substitution" and it has been well researched since the 1970s (Stockdale, 2000). However, evidence linking nutrient intake with feeding behavior was identified much earlier. Atkeson et al. (1942) identified that grazing time declined with increasing pasture digestibility; satiation was acquired more quickly when the energy density of the feed was greater and the cow ceased to expend energy grazing. Confirming these findings, a series of excellent experiments in rodents in the 1940s and 1950s identified regions of the brain responsible for intake regulation (see Roche et al., 2008) and that these regulatory regions were sensitive to nutrient intake. Roche et al. (2007b) provided evidence for such a neuroendocrine basis for substitution in grazing dairy cows when they reported that the concentration of ghrelin, a circulating hormone that signals the hunger status of the animal to the brain, declined after cows consumed concentrates in the milking parlor.

Macdonald et al. (2008b) reported a greater response to supplementary feed in New Zealand Friesian cows from a 1990s genetic strain than a 1970s genetic strain and an even greater response from North American Holstein-Friesian type cows selected exclusively for milk production. These cows were heavier and base ghrelin concentrations had increased, confirming that genetic selection had increased cow BW and levels of hunger, and increased the DMI point at which cows would succumb to satiety signals (Roche et al., 2006d). Consistent with these findings, Linnane et al. (2004) reported less of a reduction in the time spent grazing in Dutch Holstein-Friesian cows selected exclusively for milk production compared with New Zealand Friesian cows selected in a multi-trait index that also considered functional traits.

Another reason for the increase in the marginal milk production response to supplementary feeds was a reduction in the amount of consumed energy being partitioned to BCS gain. With heavy emphasis on genetic selection for milk production, less consumed energy is partitioned to BCS and is used instead for milk production (Roche et al., 2006b; McCarthy et al., 2007; Macdonald et al., 2008b). The physiological basis for this was reported by Lucy et al. (2009), when they reported that genetic selection altered the coupling of the somatotropic axis. Collectively, the results reported since the 1960s imply that the immediate milk production response to supplementary feeds has increased, but the deferred response has probably diminished. In summary, the marginal milk production response to providing grazing cows with concentrate feeds has doubled, from about 0.5 to $1.1 \mathrm{~kg}$ of milk $/ \mathrm{kg}$ of concentrate DM between the 1960s and 2017. Interestingly, Macdonald et al. (2017) noted that this response was not affected by feed type, with the response directly related to the amount of ME in the supplementary feed (i.e., $7.5 \mathrm{~g}$ of fat and protein per MJ of ME). 


\section{Using Pasture as the Forage Source in a Mixed Ration}

In systems with greater variability in pasture supply due to unpredictable rainfall or high summer temperatures (e.g., Australia, United States), a focus of recent research has been on the incorporation of pasture as the forage source to a mixed ration or high concentrate levels "slug-fed" in the milking parlor (Auldist et al., 2013). From a nutrition perspective, cow requirements can be modeled through semi-mechanistic models such as the Cornell Net Carbohydrate and Protein System (Fox et al., 1995). But at a system level, the need to calve or breed seasonally is less important because pasture constitutes such a low proportion of the cow's diet that stocking rates are much higher than would be considered in systems where pasture is the predominant nutrient source. However, the utilization of pasture grown remains paramount to the financial success of these systems and so the agronomic practices that maximize pasture growth and utilization already discussed are equally applicable. Nevertheless, the effects of such high stocking rates in conjunction with the importation of $\mathrm{N}$ and $\mathrm{P}$ in feed require consideration, particularly in sensitive river catchments and where the population of cows is dense.

\section{Offering Supplementary Feeds on the Basis of Milk Yield}

With the greater focus on per cow milk yield after World War II and technology breakthroughs that facilitated individualized feeding of cows, there was a great interest in customizing the pattern of concentrate allocation to grazing dairy cows (Leaver, 1988) as recommended by Boutflour (1928). The general belief was that higher-yielding cows would benefit more from supplementary feed than lower-yielding cows and so cows received incremental increases in concentrate allocation with increasing milk yield. Unfortunately, however, the experimental results over the last $50 \mathrm{yr}$ indicate that there is no advantage in the individualized feeding of cows (i.e., feed to yield) compared with feeding every cow in the herd the same amount of supplement (flat rate feeding; Hills et al., 2015). The lack of effect is believed to be a result of substitution; although high-yielding cows have lower substitution rates than low-yielding cows (Linnane et al., 2004), this tendency results in a greater availability of high quality pasture for the high-yielding cows when all cows receive the same amount of supplement. Herd DMI is not, therefore, increased by individualized feeding and so there is no advantage in milk production relative to flat-rate feeding (Hills et al., 2015).

\section{SYSTEMS RESEARCH}

A unique feature of the science undertaken in grazing systems during the last $60 \mathrm{yr}$ in particular has been the use of farmlet comparisons, wherein a particular strategic component of the system has been varied and the system implications of the change investigated (e.g., stocking rate's effect on production, profit, and environmental footprint; Macdonald et al., 2008a, 2011; Roche et al., 2016).

Although, in the strict scientific sense, these experiments are rarely replicated (i.e., the experimental unit is the cow), they are generally undertaken over many production seasons and, as such, are replicated in time and can be analyzed for consistency of response with time. McMeekan, in his landmark publication Grass to Milk (McMeekan, 1960), insisted that, in his experience, "it is more valuable to repeat any grassland experiment involving livestock over several years than to have several replications running in the one year." These types of experiments have played a major part in the evolution of the intensive grazing system.

Although agronomical and grazing management research has been undertaken in many universities and research stations worldwide, 2 research stations in particular have become synonymous with farm systems experimentation and the development of the modern grazing systems: Ruakura, in New Zealand, and Moorepark, in Ireland. The Ruakura Experimental Station was established in 1901, but its focus was primarily teaching and instruction until 1939, when a severe outbreak of facial eczema compelled the government to provide $£ 17,000$ for equipment and facilities to study the disease (Scott, 1997). [Facial eczema is a disease caused by a toxin (sporidesmin) produced by the spores of the fungus Pithomyces chartarum that can grow on pasture during warm and humid conditions, particularly during summer.] In 1943, McMeekan became superintendent and, from then, Ruakura became a name immediately recognized with grazing systems research. A similar government-sponsored research initiative was established in Ireland in the 1950s. Ireland was an economy very much dependent on agriculture but until the 1950s it was reeling from the effects of colonialization (12th to 20th century), World War I, civil war (early 1920s), the Great Depression (late 1920s-early 1930s) and an "economic war" with England (mid-1930s), and the restrictions associated with World War II. An Fóras Talúntais (later Teagasc) was established in 1959 and the Moorepark research station was dedicated to research in dairy production and milk harvesting research. Through the second half of the twentieth century, both Ruakura and Moorepark 
became international focal points for the development of pasture-based systems of milk production.

Many strategic components of the farm system have been evaluated, including grazing technique (i.e., rotational grazing vs. set-stocking), stocking rate, cow breed and genetic strain within breed, the system implications of nitrogen fertilizer, and supplementary feeding, and the interactions between many of these variables.

\section{Rotational Grazing}

Systems research began in earnest with a 12-yr experiment to evaluate the benefits of "controlled" grazing (i.e., what we now know as rotational grazing) versus "uncontrolled" grazing (i.e., set-stocked) at Ruakura in 1945. This subject was to be the focus of farm systems experimentation in New Zealand and, subsequently, Ireland for nearly $20 \mathrm{yr}$ (McMeekan and Walshe, 1963). Furthermore, variations of it have been investigated in component research in many other countries (Bryant et al., 1961a,b). Initially, what McMeekan (1960) described as the "relatively primitive technique" of setstocking was compared with "the system characterized by orderly disorder" (controlled rotational grazing) but at the same stocking rate (i.e., number of cows/ha). After $12 \mathrm{yr}$, McMeekan was forced to concede little if any difference in pasture or animal production between the grazing methods, which was not consistent with the adoption rate of the technique in increasingly intensified grazing systems.

At the 7th International Grassland Congress, which was held at Massey University in New Zealand, his experiment and conclusions were heavily criticized "from all quarters of the world" (McMeekan, 1960). Critics insisted that rotational grazing, which had its basis in the grazing and resting of pasture, must result in the production of more feed and that he had restricted the potential effect by failing to impose an adequate stocking rate that would allow rotational grazing to express its superiority (McMeekan, 1960). Although he argued that no one before that conference had argued a need to increase stocking rate to take advantage of the technique, in collaboration with Michael Joe Walshe from Moorepark, Ireland, he established what was to become the defining farm systems experiment on grazing techniques (McMeekan and Walshe, 1963). Over 4 "complete production seasons," rotational grazing was compared with set-stocking at 2 stocking rates in self-contained farmlets. Although stocking rate had the greatest effect on pasture utilization and milk fat production per hectare, rotational grazing out-performed set-stocking. The effect was greater at the high stocking rate and the effect increased with each successive year of the experiment. They concluded that the optimum stocking rate was 5 to $10 \%$ higher for rotational grazing than for set-stocking.

In successive decades, rotational grazing continued to evolve, with component studies that helped researchers better understand the factors influencing timing of grazing, length of the rest period, and optimized postgrazing residual for both the sward and the animal. The foundation for the technique, however, was laid in an intensive 20-yr period of investigation between 1942 and 1962. However, the final nail in the "set-stocking system coffin" was yet to come.

\section{Cow Genetics × Management Interaction}

The use of high stocking rates was deemed by many as not being applicable to the industry of the 1960s because it was believed that dairy cows used in the experiments "could hardly be considered representative of the average dairy cow in the industry" (Carter, 1964). Research cows had been bred by AI to superior sires for more than $15 \mathrm{yr}$. It was suggested that if animals of average productive ability had been used they "would have been dry by Christmas" under the severe treatments imposed (K. A. Macdonald, personal communication). To address this concern, one of the original genotype $\times$ environment experiments was established at Ruakura in the early 1960s. The objectives of the experiment were 3 -fold (Carter, 1964):

- to continue the comparisons of rotational grazing versus set-stocking under 2 stocking rates;

- to obtain a measure of the actual superiority achieved through AI; and

- to determine whether the results already obtained with the "superior" cows would also apply to the average dairy cow.

The general design of the experiment (Figure 7) was similar to the previous phase [i.e., comparing rotational grazing and set-stocking at either 2.35 (low stocking rate, LSR) or 2.95 (high stocking rate, HSR) cows/ ha], with the added fixed effect of cow genetic merit (i.e., a $2 \times 2 \times 2$ factorial arrangement). Half of the cows in the experiment were sourced from commercial dairy herds that used milk recording, but had not used AI (i.e., low-genetic-merit cows; LGM). These cows were compared with cows from the research station (i.e., high-genetic-merit cows; HGM). The transfer of an equal number of replacement cows from the experimental station to the contributing farms permitted additional comparisons of HGM and LGM cows in a range of environments. 

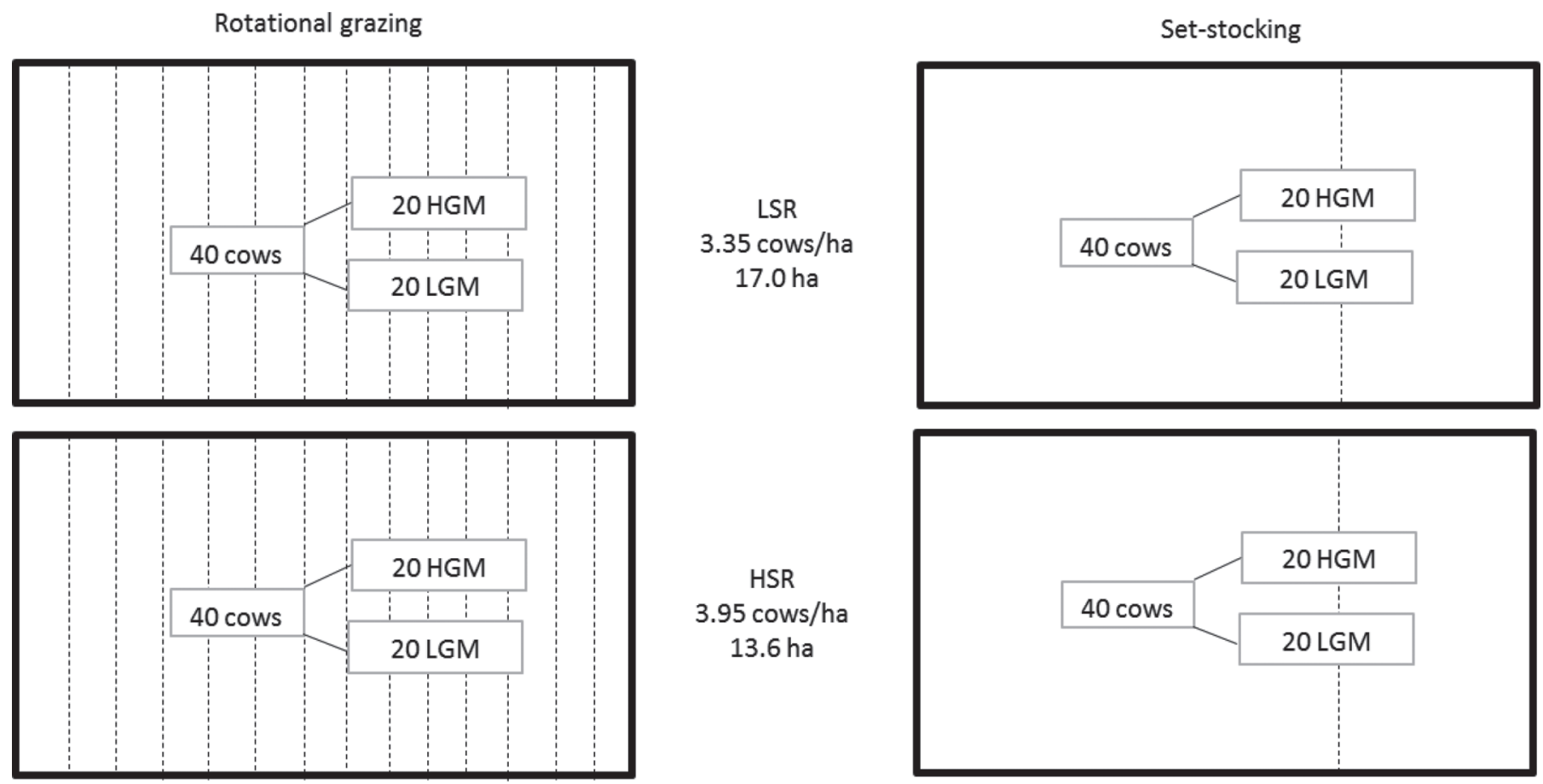

Figure 7. Design of the genotype $\times$ environment comparison experiment undertaken at Ruakura (New Zealand) over multiple years during the early 1960s. The experiment investigated the interaction between 2 stocking rates (high and low, HSR and LSR), 2 cow genetic merits (high, which was sourced from a research herd undertaking AI for more than $15 \mathrm{yr}$, and low, which were sourced from commercial dairy farms that did not use AI; HGM and LGM) under 2 grazing strategies (i.e., rotational grazing and set-stocking).

The first 3 yr of results were presented by Carter (1964). Considering the complexity of the treatment arrangement, the results were groundbreaking. In all potential comparisons, the HGM cows reflected their genetic superiority; on average, they out-produced LGM cows by $24.7 \mathrm{~kg}$ of milk fat/cow per year. Interestingly, this effect did not vary with stocking rate, indicating a lack of genotype $\times$ feeding level interaction, and that feeding levels/cow did not need to be modified to achieve the advantage of genetic selection. Because of the multiplier effect of stocking rate, the advantage of HGM over LGM increased from between 52 to $71 \mathrm{~kg}$ of milk fat/ha per year, with a $0.6 \mathrm{cow} / \mathrm{ha}$ increase in stocking rate investigated.

Confirming the previous study (McMeekan and Walshe, 1963), the negative effect of stocking rate on milk fat yield/cow was less and the positive effect on milk fat yield/hectare was greater in the rotational grazing system than in the set-stocked treatment. The increase in milk fat yield/hectare from increasing stocking rate from 3.35 to 3.95 cows/ha was $54 \mathrm{~kg}$ of milk fat/ha greater in the rotational grazing system than in the set-stocking system. Furthermore, the advantage of rotational grazing in milk fat production/cow and per hectare was $30 \%$ greater in the HGM cows than in their LGM counterparts.
This experiment was to end the debate on whether rotational grazing was superior to set-stocking among all but a few grazing enthusiasts. The advantage of rotational grazing increased under higher stocking rates and with cow genetic improvement, both system-level factors being avidly encouraged and, subsequently adopted. In grazing research, no systems-level modification has come close to equaling the effects of adopting rotational grazing and increasing stocking rate in increasing the production and utilization of pasture/ hectare and conversion of that feed to milk.

\section{Stocking Rate}

Stocking rate is defined as the number of cows/hectare or as BW/hectare to account for the lower maintenance demands and production capacity of smaller cows compared with larger cows. It is often regarded as the most important strategic decision for a grazing dairy farm, because it influences the amount of pasture consumed and milk produced per hectare (McMeekan, 1960; Macdonald et al., 2008a; McCarthy et al., 2010). In fact, McMeekan (1960) was convinced that "no more powerful force for good and for evil existed than control of the stocking rate in grassland farming." By this, he was acknowledging the existence of an optimum stock- 
ing rate, that maximized pasture utilization and milk production/hectare for the long term; too high a stocking rate would result in the "destruction" of pastures, as was often the case with native pastures "in most countries of the world" (McMeekan, 1960).

Nevertheless, McMeekan was a staunch advocate for stocking at "heavy rates" to ensure that animal and pasture productivity were maximized. Subsequent research by many, including C. P. McMeekan, A. R. Bryant, D. Browne, A. Campbell, D. McCarthy, P. McFeeley, C. W. Holmes, D. A. Clark, K. A. Macdonald, W. J. Fulkerson, J. W. Penno, L. Delaby, and P. G. Dillon, led to the development of decision rules that facilitated the dual aims of high stocking rates to optimize pasture utilization and minimizing risk to the cow associated with climatic variability and associated pasture growth (Macdonald and Penno, 1998).

Experiments to evaluate the effect of stocking rate began in Ruakura in the early 1940s and, by 1960, 6 major experiments had been undertaken (McMeekan, 1960). Increasing stocking rate resulted in an $8 \%$ lower milk fat yield/cow, for an increase of 0.26 cows/ha, but milk fat production/hectare increased by $17 \%$, on average. It led McMeekan to conclude, "in using stocking rate as a weapon to increase per acre efficiency, we must accept a lower output/animal," a fact independently verified by Mott (1960). Subsequent research confirmed this apparent conflict between per-hectare and per-cow production and acknowledged that at an optimal stocking rate, dairy cows should be able to consume $90 \%$ of the pasture they would consume in an unrestricted grazing situation (Macdonald et al., 2008a; McCarthy et al., 2010). It is not clear whether
McMeekan did not consider the economic return of the dairy farm in recommending higher stocking rates or whether he thought the increase in variable costs was less than the increased revenue. Nevertheless, a decline production per cow with increasing stocking rate was eventually going to undermine profitability-but at what stocking rate? The answer was to come some 50 yr later (Macdonald et al., 2011).

The need to optimize stocking rate and have a system transferable from the research station to the farm, led to the development of, arguably, the most complete stocking rate experiment ever undertaken (Macdonald et al., 2008a). During the late 1990s, they compared 5 different stocking rates in individual farmlets that were virtually self-contained (i.e., 2.2 to 4.4 cows/ha on a farm averaging pasture production of $18 \mathrm{t}$ of $\mathrm{DM} /$ ha). Considering that the type of feed is not important at a system level (Macdonald et al., 2017), the experiment allowed the development of an index to predict the optimum stocking rate for any farm as long as the amount of feed available/hectare (i.e., pasture and supplementary feeds) and the size of the cow (as a proxy for genetic merit) were known. The index was called the comparative stocking rate $(\mathbf{C S R} ; \mathrm{kg}$ of $\mathrm{BW} / \mathrm{t}$ of feed DM available), and subsequent economic modeling (Macdonald et al., 2011) identified the optimum stocking rate at $77 \mathrm{~kg}$ of $\mathrm{BW} / \mathrm{t}$ of feed $\mathrm{DM}$ available (i.e., without accounting for any physical wastage of feed). A subsequent reassessment of these results led to the conclusion that the optimum CSR is closer to $85 \mathrm{~kg}$ of $\mathrm{BW} / \mathrm{t}$ of DM (Table 1) and should be higher $(\sim 90 \mathrm{~kg}$ of $\mathrm{BW} / \mathrm{t}$ of feed $\mathrm{DM}$ ) when supplements are used at higher stocking rates (Macdonald et al., 2017).

Table 1. Estimated optimum stocking rate (cows/ha), accounting for size of the cow (i.e., proxy for genetic merit), the amount of pasture DM produced/ha (i.e., primary feed supply), and the amount of supplementary feed imported from off-farm ${ }^{1}$

\begin{tabular}{|c|c|c|c|c|c|c|c|c|c|c|}
\hline \multirow{2}{*}{$\begin{array}{l}\text { Supplementary feed, } \\
\mathrm{t} \text { of DM/cow }\end{array}$} & \multicolumn{5}{|c|}{$400-\mathrm{kg}$ cow } & \multicolumn{5}{|c|}{$500-\mathrm{kg}$ cow } \\
\hline & 12 & 14 & 16 & 18 & 20 & 12 & 14 & 16 & 18 & 20 \\
\hline 0.00 & $\begin{array}{c}2.6 \\
(2.7)\end{array}$ & $\begin{array}{c}3.0 \\
(3.2)\end{array}$ & $\begin{array}{c}3.4 \\
(3.6)\end{array}$ & $\begin{array}{c}3.8 \\
(4.1)\end{array}$ & $\begin{array}{c}4.3 \\
(4.5)\end{array}$ & $\begin{array}{c}2.0 \\
(2.2)\end{array}$ & $\begin{array}{c}2.4 \\
(2.5)\end{array}$ & $\begin{array}{c}2.7 \\
(2.9)\end{array}$ & $\begin{array}{c}3.1 \\
(3.2)\end{array}$ & $\begin{array}{c}3.4 \\
(3.6)\end{array}$ \\
\hline 0.25 & $\begin{array}{l}2.7 \\
(2.9)\end{array}$ & $\begin{array}{c}3.1 \\
(3.3)\end{array}$ & $\begin{array}{c}3.6 \\
(3.8)\end{array}$ & $\begin{array}{l}4.0 \\
(4.3)\end{array}$ & $\begin{array}{l}4.5 \\
(4.8)\end{array}$ & $\begin{array}{c}2.1 \\
(2.3)\end{array}$ & $\begin{array}{l}2.5 \\
(2.6)\end{array}$ & $\begin{array}{l}2.8 \\
(3.0)\end{array}$ & $\begin{array}{c}3.2 \\
(3.4)\end{array}$ & $\begin{array}{c}3.5 \\
(3.8)\end{array}$ \\
\hline 1.00 & $\begin{array}{c}3.2 \\
(3.5)\end{array}$ & $\begin{array}{l}3.7 \\
(4.1)\end{array}$ & $\begin{array}{c}4.3 \\
(4.7)\end{array}$ & $\begin{array}{c}4.8 \\
(5.3)\end{array}$ & $\begin{array}{l}5.4 \\
(5.8)\end{array}$ & $\begin{array}{l}2.5 \\
(2.7)\end{array}$ & $\begin{array}{c}2.9 \\
(3.1)\end{array}$ & $\begin{array}{c}3.3 \\
(3.5)\end{array}$ & $\begin{array}{l}3.7 \\
(4.0)\end{array}$ & $\begin{array}{c}4.1 \\
(4.4)\end{array}$ \\
\hline 1.50 & $\begin{array}{c}3.7 \\
(4.1)\end{array}$ & $\begin{array}{c}4.3 \\
(4.7)\end{array}$ & $\begin{array}{l}4.9 \\
(5.4)\end{array}$ & $\begin{array}{l}5.5 \\
(6.1)\end{array}$ & $\begin{array}{l}6.1 \\
(6.8)\end{array}$ & $\begin{array}{l}2.7 \\
(3.0)\end{array}$ & $\begin{array}{c}3.2 \\
(3.5)\end{array}$ & $\begin{array}{l}3.6 \\
(4.0)\end{array}$ & $\begin{array}{c}4.1 \\
(4.4)\end{array}$ & $\begin{array}{c}4.5 \\
(4.9)\end{array}$ \\
\hline 2.00 & $\begin{array}{c}4.3 \\
(4.9)\end{array}$ & $\begin{array}{l}5.0 \\
(5.7)\end{array}$ & $\begin{array}{l}5.8 \\
(6.5)\end{array}$ & $\begin{array}{l}6.5 \\
(7.3)\end{array}$ & $\begin{array}{c}7.2 \\
(8.2)\end{array}$ & $\begin{array}{c}3.1 \\
(3.3)\end{array}$ & $\begin{array}{l}3.6 \\
(3.9)\end{array}$ & $\begin{array}{c}4.1 \\
(4.5)\end{array}$ & $\begin{array}{l}4.6 \\
(5.0)\end{array}$ & $\begin{array}{c}5.1 \\
(5.6)\end{array}$ \\
\hline
\end{tabular}

${ }^{1}$ Optimum stocking rates are based on a comparative stocking rate (CSR) of $85 \mathrm{~kg}$ of BW/t of DM of total feed available (Macdonald et al., 2008a, 2011). In a recent publication, Macdonald et al. (2017) concluded that the optimum CSR increased to $\geq 90 \mathrm{~kg}$ of BW/t of DM of total feed available when supplementary feeds are fed; stocking rate at CSR $=90$ is presented in parentheses. 
During the last $20 \mathrm{yr}$, the effect of changes to farm management on a grazing dairy farm's environmental footprint has become increasingly important, particularly the role of the farm system in the management of fresh water through the leaching of $\mathrm{NO}_{3}$ from urine patches. Arguably, the feature most discussed in relation to $\mathrm{NO}_{3}$ leaching is farm stocking rate. A failure to understand the interacting dynamics of the system has led to the inaccurate conclusion that nitrate leaching per hectare increases with more cows on each hectare because more cows are urinating. However, this is not necessarily true. A greater stocking rate but with the same amount of $\mathrm{N}$ being imported results in a greater $\mathrm{N}$ export in milk, less surplus $\mathrm{N} /$ cow per day, a greater spread of urinary $\mathrm{N}$, a reduction in the number of cows milking during the most sensitive months for nitrate leaching, and a reduction in the size of the positive $\mathrm{N}$ balance/cow (Roche et al., 2016). All of these are likely to affect $\mathrm{NO}_{3}$ leaching/ per hectare.

In support of this, Huebsch et al. (2013) reported a reduction in the amount of $\mathrm{NO}_{3}$ leached into a vulnerable limestone aquifer over an 11-yr period, despite a $10 \%$ increase in stocking rate; this longitudinal study highlighted the complexity of how management factors interact to influence $\mathrm{NO}_{3}$ leaching. In a more controlled fashion, McCarthy et al. (2015) reported that stocking rate had no significant effect on soil solution concentrations of $\mathrm{NO}_{3}$, nitrite, ammonia, or total N. An evaluation of their treatments using an N-balance model indicated that the increased grass utilization and milk production per hectare at higher stocking rates resulted in a reduction in $\mathrm{N}$ surplus and increased $\mathrm{N}$-use efficiency. In comparison, Roche et al. (2016) reported a linear decline in $\mathrm{NO}_{3}$ leached/hectare with increasing stocking rate. They hypothesized that this was most likely because lactation length was reduced with increasing stocking rate, thereby reducing the $\mathrm{N}$ surplus in each urine patch during the most sensitive time of the year for $\mathrm{NO}_{3}$ leaching. This would reduce the amount of $\mathrm{NO}_{3}$ moving below the root zone. However, they also acknowledged the greater export of $\mathrm{N}$ in milk through increased pasture utilization and, like McCarthy et al. (2015), suggested that this could influence the $\mathrm{N}$ budget away from environmental losses.

In some cases, $\mathrm{NO}_{3}$ leaching increases with stocking rate in grazing systems. However, this is generally a function of feed importation and an increase in dietary $\mathrm{N}$ supply/hectare in association with the increased stocking rate (Ledgard et al., 2006) and not because of the stocking rate per se. With feed importation, the amount of imported $\mathrm{N}$ increases and at least some of this will be excreted in urine. More importantly, however, the timing of this feed use, and $\mathrm{N}$ excretion, often coincides with the period of greatest risk for surplus
$\mathrm{NO}_{3}$ escaping below the root zone of pasture (Roche et al., 2016). Full system analyses must be undertaken to understand the place for and cost of supplementary feeds in grazing dairy systems and their implications on the farm's environmental footprint.

\section{Breed and Genetic Strain Comparisons}

In addition to the comparison of HGM and LGM cows under rotational grazing systems and different stocking rates, several experiments have been undertaken evaluating dairy breeds and genotypes within breed from different countries (i.e., germplasm that developed under different production systems).

Jersey-Friesian Comparisons. Ahlhorn and Bryant (1992) reported that although Jersey cows produce less fat and protein yields/cow than Holstein-Friesian cows, when stocking rate was adjusted to reflect the BW differences (i.e., the same CSR but more Jersey cows/hectare), the Jersey cow produced as much milk, milk fat, and milk protein per hectare at $80 \mathrm{~kg}$ of $\mathrm{BW} / \mathrm{t}$ of feed $\mathrm{DM}$, and significantly more milk, fat, and protein per hectare at a $100 \mathrm{~kg}$ of $\mathrm{BW} / \mathrm{t}$ of feed DM CSR. As the shift in genetics was increasingly toward Holstein-Friesian, the transitional animal (i.e., the Jersey-Holstein-Friesian crossbred) was reported to be $16 \%$ heavier and, although they produced $16 \%$ more milk than the purebred Jersey comparison, they only produced 5\% more fat and 9\% more protein (Campbell, 1977). Nevertheless, as has been previously discussed, there was an insatiable drive to use Holstein-Friesian sires to increase milk production/cow.

In recent years, with the increased fertility problems with North American-derived Holstein-Friesian strains, there has been renewed interest in the Jersey cow's role in grazing systems (White et al., 2002; Prendiville et al., 2009; Beecher et al., 2014) and in particular Holstein-Friesian $\times$ Jersey crossbred animals (Buckley et al., 2014). Prendiville et al. (2009) reported that Jersey cows required 7 to $8 \%$ less total feed for every kilogram of fat and protein produced in a pasture-based system compared with Holstein-Friesian cows. These results are consistent with the reported differences in the mass of the gastrointestinal tract (i.e., $24 \%$ lighter in Jersey cows; Beecher et al., 2014), a 2 to $3 \%$ greater digestibility of DM and NDF by Jersey cows (Beecher et al., 2014), and greater use of consumed ME for productive purposes by the Jersey cow (L'Huillier et al., 1988) compared with Holstein-Friesian cows. The improvement in the efficiency of ME use, however, was only apparent in a grazing environment with restricted DMI, where Jersey cows produced $20 \%$ more milk $/ \mathrm{kg}$ of DMI (L'Huillier et al., 1988); under ad libitum feeding, this ME conversion advantage disappeared. In ad- 
dition, White et al. (2002) and Washburn et al. (2002) reported less mastitis and superior reproduction performance in Jersey cows in the United States compared with Holstein-Friesian cows, but an effect of breed on mastitis or SCS was not reported by Prendiville et al. (2010). Nevertheless, based on their superior feed conversion efficiency, particularly under limited feed availability, the Jersey breed may have an advantage over the Holstein-Friesian in low-input grazing systems. As Arnold Bryant is reputed to have said while summarizing the results of his experiment in the early 1990s, "if you're short of labor, milk Friesians; but, if you're short of land, milk Jersey." (A. M. Bryant, personal communication).

Crossbreeding Crossbreeding of pure Holstein-Friesian cows with bulls from breeds with superior fertility was a farmer-driven initiative in the 1990s to improve reproductive outcomes more quickly than selecting within a single breed. The results, where quantified, have been impressive (Buckley et al., 2014). Research conducted in Ireland during the early 2000s concluded that there was an 8-percentage-point increase in pregnancy to first service and an 11-percentage-point increase in pregnancy after 6 -wk breeding in the Norwegian Red $\times$ Holstein-Friesian compared with pure Holstein-Friesian. A further study confirmed these results, with pregnancy to first service increasing by 21 percentage points and percentage of cows pregnant after 6 -wk breeding increasing by 19 percentage points in Holstein-Friesian $\times$ Jersey crossbreds compared with purebred Holstein-Friesian cows. Similarly, in the United States, an analysis of commercial data indicated greater first-service conception rates for Scandinavian Red $\times$ Holstein-Friesian ( +6 percentage units) and Montbéliarde $\times$ Holstein-Friesian $(+10$ percentage units) compared with purebred Holstein-Friesian cows (23\%). In New Zealand, crossbred dairy cattle (primarily Jersey $\times$ Holstein-Friesian) are achieving similar rates of genetic gain for farm profit as the purebred populations, but have created additional gain derived from economic heterosis (Buckley et al., 2014). Crossbreeding was yet another technology spearheaded by farmers, with the benefit quantified and subsequently extended by science.

Evaluating Alternative Germplasm-Genotype $\times$ Diet Interactions. Until the 1990s, the accepted paradigm, globally, was that the performance of dairy cow genetics was not influenced by environment. This might be the most heavily researched topic in grazing farm systems during the last $30 \mathrm{yr}$.

A 3-year study in Ireland, completed in 1977, compared 19 successfully imported Canadian Holstein-Friesian heifers against 25 commercial Irish Friesian heifers and 25 pedigree-registered Irish Friesian heifers; the study revealed that the Canadian animals yielded 23 to $28 \%$ more than the Irish counterparts (Cunningham and O'Ferrall, 1977). In 1984, the Canadian-New Zealand genotype-by-environment study (CANZ) began (Peterson, 1988). The study involved using 20 Canadian and 20 New Zealand Holstein-Friesian bulls as AI sires for cows in 20 New Zealand and 10 Canadian herds in a 2 $\times 2$ factorial arrangement. Holmes (1995) reported that there was no interaction between the origin of the sires and the daughters' environment, but that there was a significant interaction between individual sires within strain and daughters' environment, such that the correlations between the sire proofs in the 2 countries were approximately half of the expected values.

These results were inconsistent with the previously reported lack of effect of stocking rate on the realization of genetic potential for milk production (Carter, 1964) but in agreement with subsequent Australian research that identified a scaling effect of genetic merit with feeding level (Fulkerson et al., 2008). Fulkerson et al. (2008) reported that grazing cows only expressed the milk production difference predicted from their breeding values when offered $\geq 0.8 \mathrm{t}$ of $\mathrm{DM} /$ cow of concentrates and the actual milk production difference when cows were offered $\sim 0.3 \mathrm{t}$ of DM concentrates was only $55 \%$ of the difference predicted by their genetic breeding value. Bryant et al. (2007) also predicted this scaling effect using a mechanistic model of the mammary gland; in their simulations, the benefits of increases in genetic merit were greater at high feeding levels and this was a result of a greater total number of mammary alveoli produced from conception until the end of lactation.

Holstein-Friesian germplasm from farm systems that do not involve grazing or seasonal calving were increasingly used through the 1980s and 1990s because of their superior milk production ability, as previously discussed. To evaluate the effects of such radical changes on the cow and the grazing system, several multi-year farm systems experiments were undertaken around the world (Buckley et al., 2000; Kennedy et al., 2002; Kolver et al., 2002; Horan et al., 2005a,b,c; Roche et al., 2006a; Macdonald et al., 2007, 2008b). Without exception, these studies reported reduced reproductive performance in the genetic strain originating from nongrazing systems. On average, the 6 -wk in-calf rate, a key metric of reproductive performance in grazing systems, was 15 percentage points less in the genetic strain that had evolved in nonseasonal systems. Furthermore, there was little advantage in feed conversion efficiency to these genetics in grazing systems. Although there were apparent production advantages in systems using large amounts of supplement, due to low levels of substitution (Linnane et al., 2004) and greater immediate marginal milk production responses to imported feeds 
(Kennedy et al., 2002; Horan et al., 2005b; Macdonald et al., 2008b), the greater negative energy balance in early lactation and the failure of the cow to partition toward BCS replenishment during lactation (Roche et al., 2006a; McCarthy et al., 2007) resulted in a very similar full lactation feed conversion efficiency. These experiments quantified the effects of the genotype $x$ diet interaction in grazing systems and accelerated the change to multi-trait indices that focus considerable weighting on important functional traits for grazing dairy cows.

Within a Single Germplasm-Exploiting Natural Variation. Although the Canadian-New Zealand genotype $\times$ environment trial did not identify a germplasm source $\times$ farm system interaction, an interaction between sires within strain and their daughters' environment was detected. This result would support the ability to select within germplasm for desirable traits. In the 1990s, Colin Holmes and his team at Massey University undertook an interesting study comparing cows differing only in BW. They selected 2 lines of Holstein-Friesian cows that were 60 to $80 \mathrm{~kg}$ different in their BW and compared them in a rotational grazing system. Over multiple lactations, the high BW strain offered no consistent advantages in production or efficiency and, in fact, had inferior reproduction (Laporde et al., 1998; Lopez-Villalobos et al., 2001; Tolosa et al., 2001). These results supported the negative weighting placed on BW in genetic selection for grazing cows.

Taking advantage of ability to select within germplasm for desirable traits and the substantial genetic variation for fertility traits that existed in the early 2000s in Ireland, a study was initiated at Moorepark to identify fertility phenotypes under genetic control. Cows with similar genetic merit for milk production traits but either very good (Fert+) or very poor (Fert-) genetic merit for fertility traits were identified and assembled as a single herd of animals. With a similar environment (e.g., nutritional management, health protocols, winter housing), the divergence in fertility phenotypes recorded in these 2 groups of animals was very impressive. Despite calving at similar BCS and having approximately similar milk production, Fert+ cows had earlier resumption of cyclicity, more rapid recovery of uterine health after parturition, greater BCS during lactation, more favorable blood indicators of bioenergetic status, stronger estrous expression, and a larger ovulatory follicle (and greater circulating estradiol concentrations) that subsequently resulted in a larger corpus luteum (and greater circulating progesterone concentrations; Cummins et al., 2012; Moore et al., 2014). These phenotypes collectively affected reproductive performance during the breeding period, with the Fert- cows failing to achieve fertility targets and survive in seasonal calving systems. The collective results from this investigation highlighted the importance of selecting for functional traits important to the profitability of grazing systems, such as fertility, and, for the first time, identified the fertility phenotypes under genetic control in lactating dairy cows.

\section{Supplementary Feeding}

Many multi-year farm system-level experiments have evaluated the total biological, economic, and environmental responses to intensifying the dairy system through the importation of supplementary feeds (Jonsson et al., 1999; Roche et al., 2000; Kennedy et al., 2002; Horan et al., 2005b; Jensen et al., 2005a,b; Fulkerson et al., 2008; Macdonald et al., 2008b, 2017). As previously discussed, marginal milk production responses to supplementary feeds are greatest when severe feed restrictions relative to demand result in large reductions in the milk yield of a control group (Penno, 2001). Therefore, at a system level, the way to increase the milk production response to supplements might be by increasing stocking rate or through a high stocking rate in the control treatment (Horan et al., 2005b; Macdonald et al., 2017).

In research experiments, in a scenario of low feed availability, response to additional feed is approximately $0.1 \mathrm{~kg}$ of milk or $7.5 \mathrm{~g}$ of fat and protein for $1 \mathrm{MJ}$ of ME consumed, irrespective of feed type (Macdonald et al., 2017). However, estimates of the marginal production response to supplementary feeds can be much less on commercial farms; Ramsbottom et al. (2015) reported that marginal milk production responses to purchased feeds were approximately two-thirds of those achieved in research experiments. This failure to capture the full benefit of the supplementary feed has implications for the profitability of feed use, with Ramsbottom et al. (2015) reporting a linear drop in profitability with increased use of supplementary feed above $300 \mathrm{~kg} /$ cow. From their data set, it would appear that stocking rate was not adequately increased to provide a reasonable pre-supplement feed deficit and pasture utilization decreased.

However, even in situations where stocking rate was dramatically increased and the response to supplementary feeds was as high as expected (Macdonald et al., 2017), the increase in total costs can outweigh the milk production benefit, because most expenses increase with feed use (DairyCo, 2013; Ramsbottom et al., 2015). In grazing systems, for supplementary feeding to be profitable, milk-to-feed price ratio [i.e., milk price $(\$ / \mathrm{kg}$ of milk) relative to feed price $(\$ / \mathrm{kg}$ of DM feed)] must be greater than 1.5 when grazing residuals are $35 \mathrm{~mm}$ (assuming a feed containing 11 
MJ of ME). Roche and White (2012) hypothesized that farmers could use postgrazing residuals to estimate the relative feed deficit described by Penno (2001). If their hypothesis is true, the milk-to-feed price ratio needs to be approximately $1.1,1.5$, and 4.5 when postgrazing residuals are $\sim 20,35$, or $50 \mathrm{~mm}$, respectively, to ensure a sufficient milk production response to the supplement to cover feed and nonfeed cost increases.

\section{Once-Daily Milking}

While much of the dairy world extended milking frequency to 3 or even more times per day (Bar-Peled et al., 1995; Erdman and Varner, 1995), the role of less frequent milking was investigated in grazing systems (Holmes et al., 1992; Clark et al., 2006). Because a high level of labor productivity (i.e., cows/labor unit) is a key objective in grazing systems because labor is one of the top 2 expense items (Ramsbottom et al., 2015) and because milk yield/cow is limited by DMI (Kolver and Muller, 1998), several researchers have questioned the need to milk cows twice daily and whether milking cows once each day or every $18 \mathrm{~h}$ would suffice in grazing systems with moderate yielding cows (Stelwagen et al., 2013).

Holmes et al. (1992) concluded that milking cows only once daily reduced milk production/cow but the size of the reduction was cow-dependent. These results indicated a potential opportunity to genetically select cows for suitability for once-daily milking. Clark et al. (2006) undertook a multi-year comparison, wherein they compared Jersey and Holstein-Friesian cattle milked either twice daily or once daily. They also reported a lower milk production/cow from cows milked once daily: Holstein-Friesian cows and Jersey cows produced 31 and $22 \%$ less milk and 29 and $19 \%$ less milk fat and protein, respectively. The experimental design, however, included an increase in stocking rate associated with the once-daily milking treatments (i.e., stocking rate in the herds milked once daily was 17 percentage points greater than the herds milked twice daily), and it is not possible, therefore, to separate the effect of a higher stocking rate on milk production per cow from the once-daily milking frequency effect. Nevertheless, milk production/hectare was also less, despite the increased stocking rate; Holstein-Friesian and Jersey cows produced 18 and $9 \%$ less milk/ha, on average, over the 4-yr period.

The collective results indicate that breeds or cow strains within breed with low milk volume but high component concentrations are negatively affected to a lesser degree by reduced milking frequency than are high-volume breeds. This conclusion is consistent with what we know about the feedback inhibition of milk se- cretion (Stelwagen et al., 2013); however, in agreement with Holmes et al. (1992), it indicates that there may be potential to select for cows suitable for once-daily milking in situations where milk component yield is a greater priority than milk volume.

\section{WHERE TO FROM HERE? THE NEXT 100 YEARS}

In the last $100 \mathrm{yr}$, we have witnessed almost unbelievable increases in milk production per hectare. Plant breeding and grazing techniques, customized soil nutrition, and the application of $\mathrm{N}$ fertilizer increased the amount of pasture harvested by a cow specifically bred to produce almost her own body weight in milk fat and protein from grazed pasture and successfully rebreeding within $83 \mathrm{~d}$ of calving. Farmers and applied scientists working in concert provided the infrastructure that facilitated a farm scale that, in terms of hectares farmed and cows per labor unit, could not have been foreseen when the first issue of the Journal of Dairy Science was published. However, the landscape has changed and the next $100 \mathrm{yr}$ will be very different. Research in grazing dairy systems must be more than just "tinkering" at the fringes of the system with small incremental gains in productivity. It will have 3 focal points during the next century: (1) solutions to environmental and animal welfare concerns; (2) provision of technologies that increase the number of cows milked/labor unit and reduce the skill requirements of a farm worker through the use of both structured and unstructured data that can assist in decision making; and (3) improvements in the productivity of each of the components of the farm system in an integrated manner.

\section{Social License to Farm}

As with all dairy systems in developed countries, arguably the greatest challenge facing farming and agricultural science in the next century is the provision of solutions for, and evidence against, consumer concerns regarding the animal welfare record of ruminant livestock farming and our environmental footprint. As the nutritional status of people in developed countries has increased and stabilized (i.e., year-to-year volatility in the supply of foods is nonexistent in the developed world), consumers have become increasingly concerned about the methods used to produce food. This has both advantages and disadvantages for grazing systems, as consumers in many countries believe that the welfare of cows allowed to graze is superior to those without access to grazing and, increasingly, full grazing is being viewed as superior to part grazing when climatic conditions allow (Arnott et al., 2017). Nevertheless, grazing systems involve inconsistent pasture supply and nutri- 
tive value profiles (Roche et al., 2009b) and, increasingly, consumers anthropomorphize their observations of animal farming. This can have negative consequences for grazing systems. The effect of periods of low DMI is a crucial question to determine the animal welfare requirements for supplementary feeding in grazing systems, as is the requirement for shade and shelter in inclement weather conditions and in different environments.

The social license to operate is decided locally and by only a small part of the consumer population in exportoriented dairy industries. This population tends to be more concerned about the environmental footprint of grazing dairies and, in particular, the effect of grazing systems on water quality and climate change. Wellmanaged grazing systems affect water quality primarily through the high concentration of $\mathrm{N}$ in urine deposited on a small area (i.e., the cow's urine patch). When pasture growth slows in autumn, the ability of the plant to withdraw this $\mathrm{N}$ from the soil pool is less and some moves below the root zone. When precipitation exceeds evapotranspiration in winter, this $\mathrm{N}$ can be lost to ground water in drainage (Roche et al., 2016). Depending on the current state of water in a region or country, this is either an immediately urgent area of research need or one that will become urgent with increasing dairy intensity in sensitive catchments.

Component solutions will include the breeding or feeding of cows for less $\mathrm{N}$ output in urine, breeding pastures with lower $\mathrm{N}$ content (\% of $\mathrm{DM}$ ), or using alternative forage species that have lower $\mathrm{N}$ content or possess diuretic qualities that result in an increased urine volume or a lower N content in urine. Systemslevel solutions will include the investigation of interacting components for complementarity or antagonism. However, solutions must consider the achievements to date; the proverbial baby must not be tossed with the dirty bathwater. Pasture-based dairy farming is successful because of its simplicity in daily decision making and its low infrastructure and variable costs. Any change to the base forage cannot unduly complicate the management of the grazing system; changes to animals cannot undermine productivity and resilience; and system-level changes cannot substantially increase operating expenses nor increase the need for capital infrastructure. If any of these are to change greatly, the system will not be economically viable in a world with ever-declining food prices. With these boundaries considered, these challenges are no less than those faced by the men and women of 1917 .

From a climate change perspective, grazing dairy farms will be affected in 2 ways. First, the emissions of $\mathrm{CH}_{4}$ from ruminants is a large part of the greenhouse gas (GHG) inventory in New Zealand, Ireland, and
Australia, but less of an issue in more industrialized countries. This means that international agreements to reduce GHG will affect dairy systems. Animal breeding is a potential avenue for $\mathrm{CH}_{4}$ reduction (Pinares-Patiño et al., 2013) but this is a long-term solution and will depend on the value/cost of carbon taxes and alternative strategies for reducing the farms' GHG footprint (e.g., purchasing carbon credits elsewhere). Currently, the only way to reduce $\mathrm{CH}_{4}$ emissions in grazing cows is to reduce the amount of feed being consumed. Although $\mathrm{CH}_{4}$ inhibitors are being explored (Hristov et al., 2015), currently they need to be included with the feed and may not be effective in grazing systems. Further research will be required in this space and, potentially, in conjunction with biotechnologists, the breeding of pasture species with a $\mathrm{CH}_{4}$ inhibitor contained within the cells of the plant. There is also the possibility of developing vaccines that stimulate the cow to produce antibodies against rumen methanogens (Clark, 2009). With the precautionary principle firmly in place in global governance, reducing dairy farming's contribution to GHGs will be a significant research effort in the future.

The second way in which climate change may affect dairy systems is through changes to atmospheric $\mathrm{CO}_{2}$, which enhances pasture growth, and through projected increased temperatures or altered patterns of rainfall. Considering the absolute immediacy of the dependence (i.e., daily to weekly) of grazing systems on the climate for the provision of the cow's feed supply, research will be needed to ensure the availability of resilient plants, animals, and systems suitable to a changing or more volatile climate.

\section{Automation and the Replacement of Decision Making}

Over the last century, grazing systems were renowned for the lack of employed technology, almost as if it were a badge of honor-producing milk as nature intended without the aid of depreciating assets. Milking parlors, simple aids to detect estrus, hormone intervention for anestrus, and simple tools for measuring pasture height were the only technologies that added significant value to the management of the system. This was despite farm size increasing by more than $1,000 \%$ in New Zealand, for example, over those 100 yr. However, with scale and with increasing recognition of social responsibility issues, each decision becomes more important and yet there is less time to consider the decision being made.

With scale, fewer farming families, and smaller families, animal husbandry skills are not as expertly or easily acquired as they were in the last century. Therefore, what were simple tasks, such as the early 
detection of disease or the accurate identification of cows in estrus, have become less exact. At the same time, the consumer's requirement for animal welfare management has increased and requires that farmers manage herds of cows as individuals, which will require better animal husbandry skills than historically passed down from generation to generation. This means that farmers will need near- to real-time information on each cow at his or her fingertips. Cow activity, rumen function, core temperature, changes in BW or BCS, and milk production are all easily measured with available technology. These will soon be combined with abilities to detect hormones, metabolites, and even nanoparticles in milk, all of which have the ability to contribute to the picture the farmer receives about each cow. For example, Crookenden et al. (2016) reported that the protein cargo contained in circulating exosomes in early lactation provides a picture of the metabolic health status of transition dairy cows. Exosomes are intercellular, nanoparticle messengers that can cross the blood-milk barrier. If used in conjunction with other measurable factors in milk, it will be possible to automatically draft cows for further inspection by the farmer. However, for this to occur, we need to understand the inference that changes in these biomarkers convey and, more importantly, what can be done to prevent or treat the likely animal health problem. The technology is already being developed for human medicine; however, dairy physiologists will have to work closely with researchers in the biomedical sciences to develop algorithms using machine learning technology that utilize the increasing amount of structured and unstructured data being collated about each animal. These data will enable greater phenotyping of animals and more accurate and rapid genetic selection for cow resistance to disease and resilience.

For pastures, technologies that automatically and accurately measure pasture DM yield and quality will enable improved genetic selection for economically important traits, such as non-peak DM production, digestibility, persistence, and, potentially, lower $\mathrm{CP}$ content, from an environmental mitigation perspective. Technologies will be developed to accurately, and without human interference, assign an area of pasture commensurate with the daily DMI needs of the cow and the immediate and projected pasture growth rate. Such virtual fencing technology is being considered by several research groups, but at the time of writing is still some way off. In particular, the technologies that will accurately measure pasture available and likely pasture growth to calculate the allowance will need considerable research efforts. But the unstructured data are already being collected on every "smart" device on the planet. This type of technology could automate one of the most time-consuming but important tasks in optimally managing a grazing dairy farm; that is, the assessment of farm pasture cover and the assignment of daily grazing area.

\section{Productivity Improvements}

The immense productivity improvements during the past 100 yr have been driven by well-designed component research studies to establish principles and farm systems research that investigated how these primary system components interact. Much of biological systems research has been overtaken by computer simulations (i.e., modeling), which offer the considerable advantage of being able to estimate effects over long periods quickly and inexpensively. However, sometimes they do not accurately represent what is observed in field experimentation or on farm, and they rarely account for the human capability interface. In the future, farm systems research will be an interaction between field experimentation and computer simulation modeling, with the field observations used to parameterize the models and provide confidence of accuracy, whereas the model will facilitate the prediction of effects under many environments and circumstances. One of the most important developments must be the development of a human capability model that will estimate poor to expert decision making and allow this information to be integrated into the biological modeling to provide the range of likely outcomes and to prioritize the actions that need to be undertaken well.

The current grazing model for production of milk will continue to make steady incremental gains in cow and feed genetics, and the rate of gain may even increase with greater knowledge of the effects of production and nonproduction traits on farm profitability. A greater ability to easily measure important phenotypes and develop associations with molecular signatures through an ever-increasing array of "-omics" technologies that decline in unit cost annually will accelerate genetic gain, even without the use of trans- and cisgenic biotechnologies, whose use to date has been curtailed by non-scientific regulations in most grazing regions. The focus in cow breeding will continue to be in quantifying functional traits that are linked to cow survival and health (e.g., fertility, mastitis, metabolic diseases), both because of their importance to profitability and because premature mortality is increasingly viewed as an animal welfare issue in animal production systems, even though losses are estimated to be $50 \%$ less in grazing systems than in housed systems (Compton et al., 2017). This will not diminish our ability to make 
progress in milk production, as is evidenced in Figure 6 , because voluntary removal of animals will make up a greater proportion of the total number of cows replaced and the "boarder" cow will be removed earlier than they are currently when involuntary animal removal is such a large proportion of total cows replaced.

In comparison, focus in pasture breeding will continue to shift toward more complex traits than just annual DM yield. Seasonality of pasture production - with high yields in spring, inadequate growth in summer in areas prone to moisture stress, and in winter due to low temperatures and solar irradiation-is a critical limitation to the current production system. Pasture production away from peak growth, as well as an increased focus on persistence of selected cultivar varieties, improvements in nutritive value, and any traits that could contribute to a reduction in $\mathrm{NO}_{3}-\mathrm{N}$ leaching (e.g., increased winter growth) or methane production will increasingly be the focus of pasture breeding in the next century.

\section{CONCLUSIONS}

Through the actions of many, grazing systems have evolved from primitive, poorly performing systems that used unimproved pastures and dual-purpose cows in an extensive manner to an intensive system of grazing management with highly digestible pastures and fit-for-purpose cows, and all primarily without a large increase in capital infrastructure. The Journal of Dairy Science has played a pivotal role in communicating the advancements of science throughout this period and, in particular, during the last $20 \mathrm{yr}$. Necessity is truly the "mother of invention" and the history of the modern grazing system is testimony to this. The development of the electric fence, the herringbone and rotary milking parlors, and the diluents that allowed provision of low volumes of fresh semen for AI were all specific to the need for a seasonal-calving system. Multi-year farm systems experiments were unique to grazing research because the components of the systems were more inherently intertwined than in housed systems with a predictable feed supply. These experiments helped cement some of the underlying principles of grazing management and stock husbandry. The future is bright, but a shift in research resources is needed to allay consumer concerns around animal welfare and farming's environmental footprint. This will be associated with increased use of structured and unstructured data sets being automatically collected and technologies that will individualize the care and management of the dairy cow and accelerate incremental, but permanent, gains in animal genetics for functionally important traits.

\section{REFERENCES}

Ahlhorn, G., and A. M. Bryant. 1992. Production, economic performance and optimum stocking rates of Holstein-Friesian and Jersey cows. Proc. N. Z. Soc. Anim. Prod. 52:7-9.

Anonymous. 1924. How to locate the "top-notcher" and the "boarder" cows in your herd. N. Z. Dairyman 28:81.

Arnott, G., C. P. Ferris, and N. E. O'Connell. 2017. Review: Welfare of dairy cows in continuously housed and pasture-based production systems. Animal 11:261-273. https://doi.org/10.1017/ S1751731116001336.

Atkeson, F. W., A. O. Shaw, and H. W. Cave. 1942. Grazing habits of dairy cattle. J. Dairy Sci. 25:779-784.

Atkins, P. 2016. Liquid Materialities: A History of Milk, Science and the Law. 2nd ed. Ashgate Press/Routledge, Abingdon, UK.

Auldist, M. J., L. C. Marett, J. S. Greenwood, M. Hannah, J. L. Jacobs, and W. J. Wales. 2013. Effects of different strategies for feeding supplements on milk production responses in cows grazing a restricted pasture allowance. J. Dairy Sci. 96:1218-1231. https:// doi.org/10.3168/jds.2012-6079.

Bacon, C. W. 1995. Toxic endophyte-infected tall fescue and range grasses: Historical perspectives. J. Anim. Sci. 73:861-870.

Bar-Peled, U., E. Maltz, I. Bruckental, Y. Folman, Y. Kali, H. Gacitua, A. R. Lehrer, C. H. Knight, B. Robinson, H. Voet, and H. Tagari. 1995. Relationship between frequent milking or suckling in early lactation and milk production of high producing dairy cows. J. Dairy Sci. 78:2726-2736. https://doi.org/10.3168/jds.S0022 -0302(95)76903-X.

Bargo, F., L. D. Muller, E. S. Kolver, and J. E. Delahoy. 2003. Invited review: Production and digestion of supplemented dairy cows on pasture. J. Dairy Sci. 86:1-42. https://doi.org/10.3168/jds.S0022 $-0302(03) 73581-4$

Baxter, H. D., J. R. Owen, R. C. Buckner, R. W. Hemken, M. R. Siegel, L. P. Bush, and M. J. Montgomery. 1986. Comparison of Low Alkaloid Tall Fescues and Orchardgrass for Lactating Jersey Cows. J. Dairy Sci. 69:1329-1336. https://doi.org/10.3168/jds .S0022-0302(86)80539-2.

Beecher, M., F. Buckley, S. M. Waters, T. M. Boland, D. EnriquezHidalgo, M. H. Deighton, M. O'Donovan, and E. Lewis. 2014. Gastrointestinal tract size, total-tract digestibility, and rumen microflora in different dairy cow genotypes. J. Dairy Sci. 97:3906-3917. https://doi.org/10.3168/jds.2013-7708.

Berry, D. P., M. Burke, M. O'Keefe, and P. O'Connor. 2006. Do-ityourself milk recording as a viable alternative to supervised milk recording in Ireland. Ir. J. Agric. Food Res. 45:1-12.

Blaser, R. E., R. C. Hammes, H. T. Bryant, C. M. Kincaid, W. H. Skrdla, T. H. Taylor, and W. L. Griffith. 1956. The value of forage species and mixtures for fattening steers. Agron. J. 48:508-513.

Blaxter, K. L., and N. Robertson. 1995. From Dearth to Plenty. The Modern Revolution in Food Production. Cambridge University Press, Cambridge, UK.

Bluett, S. J., E. R. Thom, D. A. Clark, K. A. Macdonald, and E. M. K. Minnee. 2003. Milksolids production from cows grazing perennial ryegrass containing AR1 or wild endophyte. Proc. NZ. Grassland Assoc. 65:83-90.

Boutflour, R. B. 1928. Limiting factors in the feeding and management of milch cows. Pages 15-20 in Report of the World's Dairy Congress, Central Hall, Westminster, London, UK. International Dairy Federation, Brussels, Belgium

Boyd, D. A., and W. J. Lessells. 1954. Influence of fertility levels on grassland output - A review of fertilizer experiments on grassland in relation to current fertilizer usage. J. Br. Grassl. Soc. 9:7-15.

Brotherstone, S., and M. Goddard. 2005. Artificial selection and maintenance of genetic variance in the global dairy cow population. Philos. Trans. R. Soc. Lond. B Biol. Sci. 360:1479-1488. https:// doi.org/10.1098/rstb.2005.1668.

Brougham, R. W. 1955. A study in rate of pasture growth. Aust. J. Agric. Res. 17:46-55.

Brougham, R. W. 1957. Pasture growth rate studies in relation to grazing management. Proc. N.Z. Soc. Anim. Prod. 17:46-55. 
Bryant, A. M., and P. J. L'Huillier. 1986. Better use of pastures. Proc. Ruakura Farmers' Conf. 38:43-51.

Bryant, H. T., R. E. Blaser, R. C. Hammes, and W. A. Hardison. 1961a. Comparison of continuous and rotational grazing of three forage mixtures by dairy cows. J. Dairy Sci. 44:1742-1750. https:// doi.org/10.3168/jds.S0022-0302(61)89949-9.

Bryant, H. T., R. E. Blaser, R. C. Hammes, and W. A. Hardison. 1961b. Method for increased milk production with rotational grazing. J. Dairy Sci. 44:1733-1741. https://doi.org/10.3168/jds.S0022 -0302(61)89948-7.

Bryant, J. R., N. Lopez-Villalobos, C. W. Holmes, J. E. Pryce, G. D. Pitman, and S. R. Davis. 2007. The effect of level of feeding, genetic merit, body condition score and age on biological parameters of a mammary gland model. Animal 1:175-183. https://doi.org/10 $.1017 /$ S1751731107657747.

Buckley, F., P. Dillon, M. Rath, and R. F. Veerkamp. 2000. The relationship between genetic merit for yield and live weight, condition score, and energy balance of spring calving Holstein Friesian dairy cows on grass based systems of milk production. J. Dairy Sci. 83:1878-1886. https://doi.org/10.3168/jds.S0022-0302(00)75060 $-0$.

Buckley, F., N. Lopez-Villalobos, and B.J. Heins. 2014. Crossbreeding Implications for dairy cow fertility and survival. Animal 8:122133. https://doi.org/10.1017/S1751731114000901.

Butler, S. T., I. A. Hutchinson, A. R. Cromie, and L. Shalloo. 2014 Applications and cost benefits of sexed semen in pasture-based dairy production systems. Animal 8:165-172.

Campbell, A. G. 1969. Grazing interval, stocking rate, and pasture production. N. Z. J. Agric. Res. 12:67-74.

Campbell, A. G. 1977. Comparative dairy production of Jerseys and Friesian-Jersey crossbreds. Proc. N.Z. Soc. Anim. Prod. 38:25-31.

Carruthers, V. R., P. G. Neil, and D. E. Dalley. 1997. Effect of altering the non-structural:structural carbohydrate ratio in a pasture diet on milk production and ruminal metabolites in cows in early and late lactation. Anim. Sci. 64:393-402.

Carter, A. H. 1964. How important is dairy merit? Proc. Ruakura Farmers' Conf. 15:188-203.

Clark, D. A., C. V. C. Phyn, M. J. Tong, S. J. Collis, and D. E. Dalley. 2006. A systems comparison of once- versus twice-daily milking of pastured dairy cows. J. Dairy Sci. 89:1854-1862. https://doi.org/ 10.3168/jds.S0022-0302(06)72254-8.

Clark, D. A., E. R. Thom, C. D. Waugh, and V. T. Burgraaf. 1999. Milk production from perennial ryegrass pastures containing different levels of endophyte. Proc. N.Z. Soc. Anim. Prod. 59:258-259.

Clark, H. 2009. Methane emissions from ruminant livestock; are they important and can we reduce them? Proc. N. Z. Grassl. Assoc. 71:73-76.

Cockayne, A. H. 1912a. Perennial ryegrass seed. N. Z. J. Agric. 5:242245.

Cockayne, A. H. 1912b. White clover seed. N. Z. J. Agric. 5:134-137.

Cohen, D. C., P. T. Doyle, C. R. Stockdale, and W. J. Wales. 2000. Pasture allowance $\mathrm{x}$ pasture intake relationships: Victorian and overseas data. Asian-australas. J. Anim. Sci. 13:119.

Compton, C. W. R., C. Heuer, P. T. Thomsen, T. E. Carpenter, C. V. C. Phyn, and S. McDougall. 2017. Invited review: A systematic literature review and meta-analysis of mortality and culling in dairy cattle. J. Dairy Sci. 100:1-16. https://doi.org/10.3168/jds .2016-11302.

Cooper, M. M. 1941. Milk production studies. Proc. N.Z. Soc. Anim. Prod. 1:25-30.

Crookenden, M. A., C. G. Walker, H. Peiris, Y. Koh, A. Heiser, J. J. Loor, K. M. Moyes, A. Murray, V. S. R. Dukkipati, J. K. Kay, S. Meier, J. R. Roche, and M. D. Mitchell. 2016. Short communication: Proteins from circulating exosomes represent metabolic state in transition dairy cows. J. Dairy Sci. 99:7661-7668. https://doi .org/10.3168/jds.2015-10786.

Cummins, S. B., P. Lonergan, A. C. O. Evans, and S. T. Butler. 2012 Genetic merit for fertility traits in Holstein cows: II. Ovarian follicular and corpus luteum dynamics, reproductive hormones, and estrus behavior. J. Dairy Sci. 95:3698-3710. https://doi.org/10 $.3168 /$ jds.2011-4976.
Cunningham, E. P., and G. J. M. O'Ferrall. 1977. Comparison of dairy production in Canadian Holsteins and Irish Friesians. Pages 49-50 in Report from Dunsinea, Moorepark and Western Research Centres.

Cunningham, I. J. 1942. Nutrition and animal health in New Zealand. Proc. N. Z. Soc. Anim. Prod. 2:23-29.

Cunningham, I. J. 1948. Tall fescue grass is poison for cattle. N. Z. J. Agric. 77:519.

Cunningham, I. J. 1958. Non-toxicity to animals of ryegrass endophyte and other endophytic fungi of New Zealand grasses. N. Z. J. Agric. Res. 1:489-497.

DairyCo. 2013. Managing costs - Key findings of the Milkbench+ dairy benchmarking programme regarding the efficiency of dairy production in Britain. DairyCo, Agriculture and Horticulture Development Board, Kenilworth, UK. https://dairy.ahdb .org.uk/resources-library/technical-information/milkbenchplus/ milkbenchplus-report-2013/\#.WZGpyfLIAkQ.

Daly, K., D. Jeffrey, and H. Tunny. 2001. The effect of soil type on phosphorus sorption capacity and desorption dynamics in Irish grassland soils. Soil Use Manage. 17:12-20.

Davies, A. 1977. Structure of the grass sward. Pages 36-44 in Proc. Int. Mtg. Anim. Prod. Temperate Grassland. Irish Grasslands and Animal Production Association, Dublin, Ireland.

de Groot, T. 1963. The influence of heavy nitrogen fertilization on the health of livestock. J. Br. Grassl. Soc. 18:112-118.

Dillon, P. G., S. Crosse, G. Stakelum, and F. Flynn. 1995. The effect of calving date and stocking rate on the performance of springcalving dairy cows. Grass Forage Sci. 50:286-299. https://doi.org/ 10.1111/j.1365-2494.1995.tb02324.x.

Donaghy, D. J. 1998. Improving the production and persistence of temperate pasture species in subtropical dairy regions of Australia. $\mathrm{PhD}$ Diss. University of Sydney, Australia.

Dougherty, W. J., and C. J. Gourley. 2014. Improving phosphorus management in intensive Australian grazing systems. Fertilizer and Lime Research Centre, Massey University, Palmerston North, New Zealand.

Ellis, W. C. 1978. Determinants of grazed forage intake and digestibility. J. Dairy Sci. 61:1828-1840.

Elting, E. C., and J. P. Lamaster. 1934. A plan and preliminary results of a permanent pasture grazing test. J. Dairy Sci. 17:425-431. https://doi.org/10.3168/jds.S0022-0302(34)93255-0.

Erdman, R. A., and M. Varner. 1995. Fixed yield responses to increased milking frequency. J. Dairy Sci. 78:1199-1203. https://doi .org/10.3168/jds.S0022-0302(95)76738-8.

Evans, R. D., P. Dillon, F. Buckley, D. P. Berry, M. Wallace, V. Ducrocq, and D. J. Garrick. 2006. Trends in milk production, calving rate and survival of cows in 14 Irish dairy herds as a result of the introgression of Holstein-Friesian genes. Anim. Sci. 82:423-433. https://doi.org/10.1079/Asc200660.

Fielden, E. D., and K. L. Macmillan. 1973. Some aspects of anoestrus in New Zealand dairy cattle. Proc. N. Z. Soc. Anim. Prod 33:87-93.

Fielden, E. D., K. L. Macmillan, and K. Moller. 1976. The pre-service anoestrous syndrome in New Zealand dairy herds. Bovine Pract. 11:10-14.

Foote, R. H. 1970. Fertility of bull semen at high extension rates in Tris-buffered extenders. J. Dairy Sci. 53:1475-1477. https://doi .org/10.3168/jds.S0022-0302(70)86417-7.

Fox, D. G., M. C. Barry, R. E. Pitt, D. K. Roseler, and W. C. Stone. 1995. Application of the Cornell Net Carbohydrate and Protein model for cattle consuming forages. J. Anim. Sci. 73:267-277.

Fulkerson, W., and D. Donaghy. 2001. Plant-soluble carbohydrate reserves and senescence-Key criteria for developing an effective grazing management system for ryegrass-based pastures: A review. Aust. J. Exp. Agric. 41:261-275. https://doi.org/10.1071/ EA00062.

Fulkerson, W., J. Wilkins, R. C. Dobos, G. M. Hough, M. E. Goddard, and T. Davison. 2001. Reproductive performance in Holstein-Friesian cows in relation to genetic merit and level of feeding when grazing pasture. Anim. Sci. 73:397-406. 
Fulkerson, W. J., T. M. Davison, S. C. Garcia, G. Hough, M. E. Goddard, R. Dobos, and M. Blockey. 2008. Holstein-Friesian dairy cows under a predominantly grazing system: Interaction between genotype and environment. J. Dairy Sci. 91:826-839. https://doi .org/10.3168/jds.2007-0147.

Fulkerson, W. J., K. Slack, K. Moore, and C. Rolfe. 1993. Management of Lolium perenne/Trifolium repens pastures in the subtropics. I. Effect of defoliation interval, seeding rate and application of $\mathrm{N}$ and lime. Aust. J. Agric. Res. 44:1947-1958.

Gallagher, R. T., E. White, and P. Mortimer. 1981. Ryegrass staggers: Isolation of potent neurotoxins lolitrem A and lolitrem B from staggers-producing pastures. N. Z. Vet. J. 29:189-190.

Ganche, E., L. Delaby, M. O'Donovan, T. M. Boland, N. Galvin, and E. Kennedy. 2013a. Post-grazing sward height imposed during the first 10 weeks of lactation: Influence on early and total lactation dairy cow production, and spring and annual sward characteristics. Livest. Sci. 157:299-311. https://doi.org/10.1016/j.livsci.2013 .08 .001 .

Ganche, E., L. Delaby, M. O'Donovan, T. M. Boland, and E. Kennedy. 2013b. Direct and carryover effect of post-grazing sward height on total lactation dairy cow performance. Animal 7:1390-1400. https://doi.org/10.1017/S1751731113000451.

Gay, K. D., N. J. O. Widmar, T. D. Nennich, A. P. Schinckel, J. B. Cole, and M. M. Schutz. 2014. Development of a Lifetime Meritbased selection index for US dairy grazing systems. J. Dairy Sci. 97:4568-4578. https://doi.org/10.3168/jds.2013-7474.

Gleeson, P. A. 1984. Responses of dairy cows to concentrate supplementation. Pages 66-116 in Moorepark 25th Anniversary Publication. Part I: Milk Production. J. O'Shea, ed. An Foras Taluntais, Moorepark, Co. Cork, Ireland.

Goff, J. P. 2006. Macromineral physiology and application to the feeding of the dairy cow for prevention of milk fever and other periparturient mineral disorders. Anim. Feed Sci. Technol. 126:237-257. https://doi.org/10.1016/j.anifeedsci.2005.08.005.

Goff, J. P., and R. L. Horst. 1997. Effects of the addition of potassium or sodium, but not calcium, to prepartum ratios on milk fever in dairy cows. J. Dairy Sci. 80:176-186. https://doi.org/10.3168/jds .S0022-0302(97)75925-3.

Hamilton, W. M. 1942. Problems of pasture feed supply. Proc. N.Z. Soc. Anim. Prod. 2:32-37.

Harris, B. L. 1995. Derivation of economic weights for the genetic worth, production worth and lactation worth indices. Livestock Technical Document, Livestock Improvement Corporation, Hamilton, New Zealand.

Harris, B. L., and E. S. Kolver. 2001. Review of holsteinization on intensive pastoral dairy farming in New Zealand. J. Dairy Sci. 84:E56-E61. https://doi.org/10.3168/jds.S0022-0302(01)70197-X.

Harvey, I. C. 1983. The Lolium endophyte: Return from anonymity. Proc. N. Z. Grassl. Assoc. 44:234-236.

Henderson, C. R. 1950. Estimation of genetic parameters. Ann. Math. Stat. 21:309. (Abstr.)

Higgs, R. J., A. J. Sheahan, K. Mandok, M. E. Van Amburgh, and J. R. Roche. 2013. The effect of starch-, fiber-, or sugar-based supplements on nitrogen utilization in grazing dairy cows. J. Dairy Sci. 96:3857-3866. https://doi.org/10.3168/jds.2012-6117.

Hills, J. L., W. J. Wales, F. R. Dunshea, S. C. Garcia, and J. R. Roche. 2015. Invited review: An evaluation of the likely effects of individualized feeding of concentrate supplements to pasture-based dairy cows. J. Dairy Sci. 98:1363-1401. https://doi.org/10.3168/ jds.2014-8475.

Holford, G. H. 1937. Some observations on pasture management in New Zealand. Pages 458-463 in Proc. 4th Int. Grassl. Congr., Aberystwyth, Wales. Welsh Plant Breeding Station, Aberystwyth, Wales.

Holmes, C. W. 1995. Breeding and feeding the high genetic merit dairy cow. Pages 51-66 in Br. Soc. Anim. Sci. Occasional Publication No. 19. British Society of Animal Science, Penicuik, UK.

Holmes, C. W., G. F. Wilson, D. D. S. MacKenzie, and J. Purchas. 1992. The effects of milking once daily throughout lactation on the performance of dairy cows grazing on pasture. Proc. N. Z. Soc. Anim. Prod. 52:13-16.
Horan, B., P. Dillon, D. P. Berry, P. O'Connor, and M. Rath. 2005a. The effect of strain of Holstein-Friesian, feeding system and parity on lactation curves characteristics of spring-calving dairy cows. Livest. Prod. Sci. 95:231-241. https://doi.org/10.1016/j.livprodsci .2004.12.021.

Horan, B., P. Dillon, P. Faverdin, L. Delaby, F. Buckley, and M. Rath. 2005b. The interaction of strain of Holstein-Friesian cows and pasture-based feed systems on milk yield, body weight, and body condition score. J. Dairy Sci. 88:1231-1243. https://doi.org/10.3168/ jds.S0022-0302(05)72790-9.

Horan, B. J. F. Mee, P. O'Connor, M. Rath, and P. Dillon. 2005c. The effect of strain of Holstein-Friesian cow and feeding system on postpartum ovarian function, animal production and conception rate to first service. Theriogenology 63:950-971. https://doi.org/ 10.1016/j.theriogenology.2004.05.014.

Hoveland, C. S. 2009. Origin and history. Pages 3-10 in Tall Fescue for the Twenty-first Century. Agron. Monogr. 53. H. A. Fribourg, D. B. Hannaway, C. P. West, ed. ASA, CSSA, SSSA, Madison, WI. https://doi.org/10.2134/agronmonogr53.c1.

Hristov, A. N., J. Oh, F. Giallongo, T. W. Frederick, M. T. Harper, H. L. Weeks, A. F. Branco, P. J. Moate, M. H. Deighton, S. R. O. Williams, M. Kindermann, and S. Duval. 2015. An inhibitor persistently decreased enteric methane emission from dairy cows with no negative effect on milk production. Proc. Natl. Acad. Sci. USA 112:10663-10668. https://doi.org/10.1073/pnas.1504124112.

Huebsch, M., B. Horan, P. Blum, K. G. Richards, J. Grant, and O Fenton. 2013. Impact of agronomic practices of an intensive dairy farm on nitrogen concentrations in a karst aquifer in Ireland. Agric. Ecosyst. Environ. 179:187-199. https://doi.org/10.1016/j.agee 2013.08.021.

Humphreys, L. R. 2005. A brief history of the International Grassland Congress. Pages 45-52 in Proc. XX Int. Grassl. Congr., Dublin, Ireland. Wageningen Academic Publishers, Wageningen, the Netherlands.

Hunt, W. F., and H. S. Easton. 1989. Fifty years of ryegrass research in New Zealand. Proc. N. Z. Grassl. Assoc. 50:11-23.

Hutchinson, I. A., L. Shalloo, and S. T. Butler. 2013. Expanding the dairy herd in pasture-based systems: The role of sexed semen use in virgin heifers and lactating cows. J. Dairy Sci. 96:6742-6752. https://doi.org/10.3168/jds.2012-6476.

Hutton, J. B., and O. F. Parker. 1973. The significance of differences in levels of feeding, before and after calving, on milk yield under intensive grazing. N. Z. J. Agric. Res. 16:95-104. https://doi.org/ 10.1080/00288233.1973.10421167.

James, J. F. 1941. Artificial insemination of cattle. Proc. N. Z. Soc. Anim. Prod. 1:58.

James, J. F. 1946. The relationship of artificial insemination to future dairy cattle breeding. Proc. N. Z. Soc. Anim. Prod. 5:59-70.

Jensen, R. N., P. C. Beukes, D. A. Clark, and K. A. Macdonald. 2005a Modelling dairy system efficiencies. Proc. N. Z. Soc. Anim. Prod. 65:203-208.

Jensen, R. N., D. A. Clark, and K. A. Macdonald. 2005b. Resource efficient dairying trial: Measurement criteria for farm systems over a range of resource use. Proc. N. Z. Grassl. Assoc. 67:47-52.

Jones, V. 1988. 50 years of power fencing. Proc. N. Z. Grassl. Assoc. 49:145-149.

Jonsson, N. N., W. J. Fulkerson, P. M. Pepper, and M. R. Mcgowan. 1999. Effect of genetic merit and concentrate feeding on reproduction of grazing dairy cows in a subtropical environment. J. Dairy Sci. 82:2756-2765. https://doi.org/10.3168/jds.S0022 -0302(99)75532-3.

Journet, M., and C. Demarquilly. 1979. Grazing. Pages 295-321 in Feeding Strategy for the High Yielding Dairy Cow. W. H. Broster and H. Swan, ed. Granada, London, UK.

Keady, T. W., C. S. Mayne, D. A. Fitzpatrick, and M. A. McCoy 2001. Effect of concentrate feed level in late gestation on subsequent milk yield, milk composition, and fertility of dairy cows. J. Dairy Sci. 84:1468-1479. https://doi.org/10.3168/jds.S0022 -0302(01)70180-4.

Kennedy, J., P. Dillon, P. Faverdin, L. Delaby, F. Buckley, and M. Rath. 2002. The influence of cow genetic merit for milk production 
on response to level of concentrate supplementation in a grassbased system. Anim. Sci. 75:433-445.

Kolver, E. S., and L. D. Muller. 1998. Performance and nutrient intake of high producing Holstein cows consuming pasture or a total mixed ration. J. Dairy Sci. 81:1403-1411. https://doi.org/10.3168/ jds.S0022-0302(98)75704-2.

Kolver, E. S., J. R. Roche, M. J. de Veth, P. L. Thorne, and A. R. Napper. 2002. Total mixed ratios versus pasture diets. Evidence for a genotype $\mathrm{x}$ diet interaction in dairy cow performance. Proc. N. Z. Soc. Anim. Prod. 62:246-251.

L'Huillier, P. J., C. R. Parr, and A. M. Bryant. 1988. Comparative performance and energy metabolism of Jerseys and Friesians in early-mid lactation. Proc. N.Z. Soc. Anim. Prod. 48:231-235.

L'Huillier, P. J., and N. A. Thomson. 1988. Estimation of herbage mass in ryegrass-white clover dairy pastures. Proc. N. Z. Grassl. Assoc. 49:117-122.

Lancaster, R. J. 1947. The nutritive status of New Zealand pastures. Proc. N.Z. Soc. Anim. Prod. 7:125-128.

Laporde, D., C. W. Holmes, J. G. Garcia-Muniz, and J. Wichtel. 1998. Reproductive performance of Holstein-Friesian cows differing genetically in live weight. Proc. N. Z. Soc. Anim. Prod. 58:73-75.

Lazenby, A. 1981. British grasslands; past, present and future. Grass Forage Sci. 36:243-266. https://doi.org/10.1111/j.1365-2494.1981 .tb01563.x

Leaver, J. D. 1985. Milk production from grazed temperate grassland. J. Dairy Res. 52:313-344.

Leaver, J. D. 1988. Level and pattern of concentrate allocation to dairy cows. Pages 315-326 in Nutrition and Lactation in the Dairy Cow. P. C. Garnsworthy, ed. University of Nottingham, Nottingham, UK

Ledgard, S. F., M. Sprosen, A. Judge, S. Lindsey, R. Jensen, D. Clark, and J. Luo. 2006. Nitrogen leaching as affected by dairy intensification and mitigation practices in the resources-efficient dairying (RED) trial. Pages 263-268 in Implementing Sustainable Nutrient Management Strategies in Agriculture. L. Curry and J. Hanley, ed. Massey University Press, Palmerston North, New Zealand.

Lee, J. M., D. J. Donaghy, and J. R. Roche. 2008a. Effect of defoliation severity on regrowth and nutritive value of perennial ryegrass dominant swards. Agron. J. 100:308-314. https://doi.org/10.2134/ agronj2007.0099.

Lee, J. M., D. J. Donaghy, and J. R. Roche. 2008b. Short communication: Effect of postgrazing residual pasture height on milk production. J. Dairy Sci. 91:4307-4311. https://doi.org/10.3168/jds.2008 -1188 .

Lee, J. M., P. Sathish, D. J. Donaghy, and J. R. Roche. 2010. Plants modify biological processes to ensure survival following carbon depletion: A Lolium perenne model. PLoS One 5:e12306. https:// doi.org/10.1371/journal.pone.0012306.

Lees, F. T., C. P. McMeekan, and L. R. Wallace. 1948. The relationship between level of nutrition during the dry period and subsequent production of dairy cattle. Proc. N. Z. Soc. Anim. Prod. 8:61-63.

Linnane, M., B. Horan, J. Connolly, P. O'Connor, F. Buckley, and P. Dillon. 2004. The effect of strain of Holstein-Friesian and feeding system on grazing behaviour, herbage intake and productivity in the first lactation. Anim. Sci. 78:169-178.

Lopez-Villalobos, N., V. Lemus-Ramirez, C. W. Holmes, and D. J. Garrick. 2001. Lactation curves for milk traits, live weight and body condition score for heavy and light Holstein-Friesian cows. Proc. N. Z. Soc. Anim. Prod. 61:217-220.

Lowman, B. G., N. A. Scott, and S. H. Somerville. 1976. Condition scoring of cattle. East of Scotland College of Agriculture, Bulletin No. 6, Edinburgh, UK.

Lucy, M. C., G. A. Verkerk, B. E. Whyte, K. A. Macdonald, L. Burton, R. T. Cursons, J. R. Roche, and C. W. Holmes. 2009. Somatotropic axis components and nutrient partitioning in genetically diverse dairy cows managed under different feed allowances in a pasture system. J. Dairy Sci. 92:526-539. https://doi.org/10.3168/ jds.2008-1421.
Macdonald, K., and J. Penno. 1998. Management decision rules to optimise milksolids production on dairy farms. Proc. N. Z. Soc. Anim. Prod. 58:132-135.

Macdonald, K., and J. R. Roche. 2004. Condition Scoring Made Easy. 2nd ed. DairyNZ, Hamilton, New Zealand.

Macdonald, K. A., D. Beca, J. W. Penno, J. A. S. Lancaster, and J. R. Roche. 2011. Short communication: Effect of stocking rate on the economics of pasture-based dairy farms. J. Dairy Sci. 94:25812586. https://doi.org/10.3168/jds.2010-3688.

Macdonald, K. A., L. R. McNaughton, G. A. Verkerk, J. W. Penno, L. J. Burton, D. P. Berry, P. J. S. Gore, J. A. S. Lancaster, and C. W. Holmes. 2007. A comparison of three strains of Holstein-Friesian cows grazed on pasture: Growth, development, and puberty. J. Dairy Sci. 90:3993-4003. https://doi.org/10.3168/jds.2007-0119.

Macdonald, K. A., J. W. Penno, J. A. S. Lancaster, A. M. Bryant, J. M. Kidd, and J. R. Roche. 2017. Production and economic responses to intensification of pasture-based dairy production systems. J. Dairy Sci. 100:6602-6619. https://doi.org/10.3168/jds .2016-1249.

Macdonald, K. A., J. W. Penno, J. A. S. Lancaster, and J. R. Roche. 2008a. Effect of stocking rate on pasture production, milk production, and reproduction of dairy cows in pasture-based systems. J. Dairy Sci. 91:2151-2163. https://doi.org/10.3168/jds.2007-0630.

Macdonald, K. A., and J. R. Roche. 2016. Back to the future-Making pasture work for you this spring. DairyNZ Tech. Ser. 30:7-10.

Macdonald, K. A., G. A. Verkerk, B. S. Thorrold, J. E. Pryce, J. W Penno, L. R. McNaughton, L. J. Burton, J. A. S. Lancaster, J. H. Williamson, and C. W. Holmes. 2008b. A comparison of three strains of Holstein-Friesian grazed on pasture and managed under different feed allowances. J. Dairy Sci. 91:1693-1707. https://doi .org/10.3168/jds.2007-0441.

Macmillan, K. L. 2002. Advances in bovine theriogenology in New Zealand. 1. Pregnancy, parturition and the postpartum period. N. Z. Vet. J. 50:67-73.

Macmillan, K. L., and R. J. Curnow. 1977. Tailpainting: A simple form of oestrous detection in New Zealand dairy herds. N. Z. J. Exp. Agric. 5:357-361.

Macmillan, K. L., R. J. Curnow, and G. R. Morris. 1977a. Oestrus synchronisation with a prostaglandin analogue. I. Systems in lactating dairy cattle. N. Z. Vet. J. 25:366-372.

Macmillan, K. L., E. D. Fielden, and R. J. Curnow. 1977b. Factors influencing A.B. conception rates: VIII. Effects of non-oestrous inseminations and return patterns after second insemination. N. Z J. Exp. Agric. 5:123-127.

Macmillan, K. L., E. D. Fielden, and J. D. Watson. 1975. The anoestrous syndrome in New Zealand dairy cattle. 2. Some factors influencing submission rates in Taranaki herds. N. Z. Vet. J. 23:4-8.

Macmillan, K. L., and H. V. Henderson. 1984. Analysis of the variation in the interval from an injection of prostaglandin F2 $\alpha$ to oestrus as a method of studying patterns of follicle development during dioestrus in cattle. Anim. Reprod. Sci. 6:245-254.

Macmillan, K. L., and A. J. Peterson. 1993. A new intravaginal progesterone releasing device for cattle (CIDR-B) for oestrus synchronization, increasing pregnancy rates and the treatment of postpartum anoestrus. Anim. Reprod. Sci. 33:1-25.

Macmillan, K. L., and J. D. Watson. 1971. Short estrous cycles in New Zealand dairy cattle. J. Dairy Sci. 54:1526-1529.

Macmillan, K. L., and J. D. Watson. 1973. A.B in New Zealand dairy herds. II. Interactions between conception rate and submission rate on the proportion of the herd reported in calf to A.B. N. Z. J. Exp. Agric. 1:309-314.

McCarthy, B., L. Delaby, K. M. Pierce, F. Journot, and B. Horan. 2010. A meta-analysis of the impact of stocking rate on the productivity of pasture-based milk production systems. Adv. Anim. Biosci. 1:148 https://doi.org/10.1017/S2040470010002918.

McCarthy, B., L. Delaby, K. M. Pierce, J. McCarthy, C. Fleming, A. Brennan, and B. Horan. 2016. The multi-year cumulative effects of alternative stocking rate and grazing management practices on pasture productivity and utilization efficiency. J. Dairy Sci. 99:3784-3797. https://doi.org/10.3168/jds.2015-9763. 
McCarthy, J., L. Delaby, D. Hennessy, B. McCarthy, W. Ryan, K. M. Pierce, A. Brennan, and B. Horan. 2015. The effect of stocking rate on soil solution nitrate concentrations beneath a free-draining dairy production system in Ireland. J. Dairy Sci. 98:4211-4224. https://doi.org/10.3168/jds.2014-8693.

McCarthy, S., D. P. Berry, P. Dillon, M. Rath, and B. Horan. 2007. Influence of Holstein-Friesian strain and feed system on body weight and body condition score lactation profiles. J. Dairy Sci. 90:1859 1869. https://doi.org/10.3168/jds.2006-501.

McCloy, N. 2014. Dairy Nation-The Story of Dairy Farming in New Zealand. Random House, Auckland, New Zealand.

McDonagh, J., M. O’Donovan, M. McEvoy, and T. J. Gilliland. 2016. Genetic gain in perennial ryegrass (Lolium perenne) varieties 1973 to 2013. Euphytica 212:187-199.

McDougall, S. 2001. Effects of periparturient diseases and conditions on the reproductive performance of New Zealand dairy cows. N. Z. Vet. J. 49:60-67. https://doi.org/10.1080/00480169.2001.36204.

McDougall, S., C. R. Burke, K. L. Macmillan, and N. B. Williamson. 1995. Follicle patterns during extended periods of postpartum anovulation in pasture-fed dairy cows. Res. Vet. Sci. 58:212-216.

McLennan, E. I. 1920. The endophyte fungus of Lolium. Part I. Proc. R. Soc. Vic. 32:252-301.

McMeekan, C. 1960. Grass to Milk-A New Zealand Philosophy. New Zealand Dairy Exporter, Wellington, New Zealand.

McMeekan, C., and M. Walshe. 1963. The interrelationships of grazing methods and stocking rate on the efficiency of pasture utilisation by dairy cattle. J. Agric. Sci. 61:147-166.

McMeekan, C. P. 1947. Pasture and animal production. Proc. N. Z. Soc. Anim. Prod. 7:13-26.

McMeekan, C. P. 1952. Interdependence of grassland and livestock on agricultural production. Pages 149-161 in Proc. 6th International Grassland Congress, Pennsylvania.

McMeekan, C. P. 1953. The 1952 International Grassland Congress. Proc. Ruakura Farmers' Conference. 119-124.

McMeekan, C. P. 1957. The advantages of controlled grazing. Proc. Ruakura Farmers' Conf. 9:223-230.

Melville, J., and P. D. Sears. 1941. Pasture utilisation by the animal. Proc. N. Z. Soc. Anim. Prod. 1:31-37.

Meuwissen, T. H. E., B. J. Hayes, and M. E. Goddard. 2001. Prediction of total genetic value using genome-wide dense marker maps. Genetics 157:1819-1829.

Milne, G. D. 2007. Technology transfer of novel ryegrass endophytes in New Zealand. Pages 237-239 in Proc. 6th Int. Symp. Fungal Endophytes of Grasses, Christchurch, New Zealand. NZ Grassland Association, Christchurch, New Zealand.

Moller, K., K. L. Macmillan, and P. Shannon. 1972. Site of insemination and subsequent non-return rates in cows. N. Z. J. Agric. Res. 15:252-254. https://doi.org/10.1080/00288233.1972.10421251.

Moore, S. G., S. Scully, J. A. Browne, T. Fair, and S. T. Butler. 2014. Genetic merit for fertility traits in Holstein cows: V. Factors affecting circulating progesterone concentrations. J. Dairy Sci. 97:5543-5557. https://doi.org/10.3168/jds.2014-8133.

Morton, J. M. 2010. Interrelationships between herd-level reproductive performance measures based on intervals from initiation of the breeding program in year-round and seasonal calving dairy herds. J. Dairy Sci. 93:901-910.

Morton, J. M., M. J. Auldist, M. L. Douglas, and K. L. Macmillan. 2016. Associations between milk protein concentration, milk yield, and reproductive performance in dairy cows. J. Dairy Sci. 99:10033-10043.

Mott, G. O. 1960. Grazing pressure and the measurement of pasture production. Pages 606-611 in Proc. 8th Int. Grassl. Congr., Reading, UK. University of Reading, Reading, UK.

Mueller, J. P. 1986. An overview of the tall fescue endophyte problem in the U.S.A. Proc. N. Z. Grassl. Assoc. 47:191-196.

Mulvany, P. 1977. Dairy cow condition scoring. Handout No. 4468. National Institute for Research in Dairying. Reading, UK.

Murphy, C., L. Shalloo, and S. Butler. 2015. Potential benefits of sexed semen to Ireland. Pages 87-88 in Irish Dairying-Sustainable Expansion. Proc. Moorepark Open Day 2015. P. Dillon, ed. Teagasc,
Animal \& Grassland Research and Innovation Centre, Moorepark, Co. Cork, Ireland.

Murphy, C., L. Shalloo, I. A. Hutchinson, and S. T. Butler. 2016. Expanding the dairy herd in pasture-based systems: The role of sexed semen within alternative breeding strategies. J. Dairy Sci. 99:6680-6692. https://doi.org/10.3168/jds.2015-10378.

Nation, D. P., C. R. Burke, F. M. Rhodes, and K. L. Macmillan. 1999 The inter-ovarian distribution of dominant follicles is influenced by the location of the corpus luteum of pregnancy. Anim. Reprod. Sci. 56:169-176. https://doi.org/10.1016/S0378-4320(99)00034-2.

Neill, J. C. 1940. The endophyte of ryegrass (Lolium perenne). N. Z. J. Sci. Technol. A21:280-291.

Norton, J. I. 2014. Effect of supplementation and grazing residual on dairy cow production. Honors Thesis. Lincoln University, Canterbury, New Zealand.

O'Connor, M. B., R. D. Longhurst, T. J. Johnston, and F. N. Portegys. 2001. Fertiliser requirements for peat soils in the Waikato region. Proc. N. Z. Grassl. Assoc. 63:47-51.

O'Donovan, M., P. Dillon, M. Rath, and G. Stakelum. 2002. A comparison of four methods of herbage mass estimation. Ir. J. Agric. Food Res. 41:17-27.

Paterson, R. 1965. Milk from grass. The Massey Ferguson Papers No. 2. Massey Ferguson, United Kingdom.

Penno, J. W. 2001. Toward a predictive model of supplementary feeding response from grazing dairy cows. Proc. N.Z. Soc. Anim. Prod. 61:229-233.

Peterson, R. 1988. Comparison of Canadian and New Zealand sires in New Zealand for production, weight and conformation traits. Research Bulletin No. 5. Livestock Improvement Corp., Hamilton, New Zealand.

Pinares-Patiño, C. S., S. M. Hickey, E. A. Young, K. G. Dodds, S MacLean, G. Molano, E. Sandoval, H. Kjestrup, R. Harland, C. Hunt, N. K. Pickering, and J. C. McEwan. 2013. Heritability estimates of methane emissions from sheep. Animal 7(Suppl. 2):316321. https://doi.org/10.1017/S1751731113000864.

Plozza, K. L., D. S. Beggs, P. D. Mansell, C. B. Blackwood, and M. F. Pyman. 2016. Postpartum anoestrus in five seasonally calving dairy farms in Victoria, Australia. Aust. Vet. J. 94:293-298.

Popay, A. J., and D. D. Rowan. 1994. Endophytic fungi as mediators of plant-insect interactions. Pages 84-103 in Insect-Plant Interactions. E. Bernays, ed. CRC Press, Boca Raton, FL.

Pratt, A. D., and J. L. Haynes. 1950. Herd performance on Kentucky 31 tall fescue. Ohio Farm Home Res. 35:10-11.

Prendiville, R., K. M. Pierce, and F. Buckley. 2009. An evaluation of production efficiencies among lactating Holstein-Friesian, Jersey, and Jersey x Holstein-Friesian cows at pasture. J. Dairy Sci. 92:6176-6185. https://doi.org/10.3168/jds.2009-2292.

Prendiville, R., K. M. Pierce, and F. Buckley. 2010. A comparison between Holstein-Friesian and Jersey dairy cows and their F1 cross with regard to milk yield, somatic cell score, mastitis, and milking characteristics under grazing conditions. J. Dairy Sci. 93:27412750. https://doi.org/10.3168/jds.2009-2791.

Ramsbottom, G., B. Horan, D. P. Berry, and J. R. Roche. 2015. Factors associated with the financial performance of spring-calving, pasture-based dairy farms. J. Dairy Sci. 98:3526-3540. https://doi .org/10.3168/jds.2014-8516.

Raymond, W. F. 1981. Grassland Research. Page 311-323 in Agricultural Research 1931-1981. A History of the Agricultural Research Council and a Review of Developments in Agricultural Science During the Last Fifty Years. G. W. Cooke, ed. Agricultural Research Council, London, UK.

Rhodes, F. M., S. McDougall, C. R. Burke, G. A. Verkerk, and K. L. Macmillan. 2003. Invited review: Treatment of cows with an extended postpartum anestrous interval. J. Dairy Sci. 86:1876-1894. https://doi.org/10.3168/jds.S0022-0302(03)73775-8.

Riddet, W., and I. L. Campbell. 1943. Lactation curves of cows fed on pasture and pasture grains. Proc. N.Z. Soc. Anim. Prod. 3:86-95.

Roberts, A. H. C., and N. A. Thomson. 1988. The consequences of not applying superphosphate fertiliser on Taranaki dairy pasture. Proc. N. Z. Grassl. Assoc. 49:161-165. 
Robins, C., C. R. Stockdale, J. Crosby, and J. Morton. 2002. The Condition Magician. Department of Natural Resources and Environment, Victoria, Australia.

Roche, J., and R. White. 2012. Production responses to supplements in pasture-based systems. VetScript October:20-23.

Roche, J. R. 2007. Milk production responses to pre- and postcalving dry matter intake in grazing dairy cows. Livest. Sci. 110:12-24. https://doi.org/10.1016/j.livsci.2006.08.016.

Roche, J. R. 2017. Nutrition management of grazing dairy cattle. Pages 251-272 in Achieving Sustainable Production of Milk. Burleigh Dodds Science Publishing, Cambridge, UK. In press.

Roche, J. R., D. Berry, and E. Kolver. 2006a. Holstein-Friesian strain and feed effects on milk production, body weight, and body condition score profiles in grazing dairy cows. J. Dairy Sci. 89:35323543.

Roche, J. R., and D. P. Berry. 2006. Periparturient climatic, animal, and management factors influencing the incidence of milk fever in grazing systems. J. Dairy Sci. 89:2775-2783. https://doi.org/10 .3168/jds.S0022-0302(06)72354-2.

Roche, J. R., D. P. Berry, and E. S. Kolver. 2006b. Holstein-Friesian strain and feed effects on milk production, body weight, and body condition score profiles in grazing dairy cows. J. Dairy Sci. 89:3532-3543.

Roche, J. R., D. Blache, J. K. Kay, D. R. Miller, A. J. Sheahan, and D. W. Miller. 2008. Neuroendocrine and physiological regulation of intake with particular reference to domesticated ruminant animals. Nutr. Res. Rev. 21:207-234. https://doi.org/10.1017/ S0954422408138744.

Roche, J. R., D. Dalley, P. Moate, C. Grainger, M. Hannah, F. O'Mara, and M. Rath. 2000. Variations in the dietary cation-anion difference and the acid-base balance of dairy cows on a pasture-based diet in south-eastern Australia. Grass Forage Sci. 55:26-36.

Roche, J. R., D. Dalley, P. Moate, C. Grainger, M. Rath, and F. O. Mara. 2003a. A low dietary cation-anion difference precalving and calcium supplementation postcalving increase plasma calcium but not milk production in a pasture-based system. J. Dairy Sci. 86:2658-2666. https://doi.org/10.3168/jds.S0022-0302(03)73861 -2 .

Roche, J. R., D. Dalley, P. Moate, C. Grainger, M. Rath, and F. O'Mara. 2003b. Dietary cation-anion difference and the health and production of pasture-fed dairy cows 2. Nonlactating periparturient cows. J. Dairy Sci. 86:979-987. https://doi.org/10.3168/jds .S0022-0302(03)73681-9.

Roche, J. R., D. Dalley, and F. P. O’Mara. 2007a. Effect of a metabolically created systemic acidosis on calcium homeostasis and the diurnal variation in urine $\mathrm{pH}$ in the non-lactating pregnant dairy cow. J. Dairy Res. 74:34-39. https://doi.org/10.1017/ S0022029906002123.

Roche, J. R., N. C. Friggens, J. K. Kay, M. W. Fisher, K. J. Stafford, and D. P. Berry. 2009a. Invited review: Body condition score and its association with dairy cow productivity, health, and welfare. J. Dairy Sci. 92:5769-5801. https://doi.org/10.3168/jds.2009-2431.

Roche, J. R., A. Heiser, M. D. Mitchell, M. A. Crookenden, C. G. Walker, J. K. Kay, M. V. Riboni, J. J. Loor, and S. Meier. 2017a. Strategies to gain body condition score in pasture-based dairy cows during late lactation and the far-off nonlactating period and their interaction with close-up dry matter intake. J. Dairy Sci. 100:1720-1738. https://doi.org/10.3168/jds.2016-11591.

Roche, J. R., J. K. Kay, C. V. C. Phyn, S. Meier, J. M. Lee, and C. R. Burke. 2010. Dietary structural to nonfiber carbohydrate concentration during the transition period in grazing dairy cows. J. Dairy Sci. 93:3671-3683. https://doi.org/10.3168/jds.2009-2868.

Roche, J. R., E. S. Kolver, and J. K. Kay. 2005. Influence of precalving feed allowance on periparturient metabolic and hormonal responses and milk production in grazing dairy cows. J. Dairy Sci. 88:677-689. https://doi.org/10.3168/jds.S0022-0302(05)72732-6.

Roche, J. R., S. F. Ledgard, M. S. Sprosen, S. B. Lindsey, J. W. Penno, B. Horan, and K. A. Macdonald. 2016. Increased stocking rate and associated strategic dry-off decision rules reduced the amount of nitrate-N leached under grazing. J. Dairy Sci. 99:5916-5925. https://doi.org/10.3168/jds.2016-11024.
Roche, J. R., J. M. Lee, and D. P. Berry. 2006c. Pre-conception energy balance and secondary sex ratio-partial support for the TriversWillard hypothesis in dairy cows. J. Dairy Sci. 89:2119-2125. https://doi.org/10.3168/jds.S0022-0302(06)72282-2.

Roche, J. R., K. A. Macdonald, K. E. Schütz, L. R. Matthews, G. A. Verkerk, S. Meier, J. J. Loor, A. R. Rogers, J. McGowan, S. R. Morgan, S. Taukiri, and J. R. Webster. 2013. Calving body condition score affects indicators of health in grazing dairy cows. J. Dairy Sci. 96:5811-5825. https://doi.org/10.3168/jds.2013-6600.

Roche, J. R., S. Meier, A. Heiser, M. D. Mitchell, C. G. Walker, M. A. Crookenden, M. V. Riboni, J. J. Loor, and J. K. Kay. 2015. Effects of precalving body condition score and prepartum feeding level on production, reproduction, and health parameters in pasture-based transition dairy cows. J. Dairy Sci. 98:7164-7182. https://doi.org/ 10.3168/jds.2014-9269.

Roche, J. R., J. Morton, and E. S. Kolver. 2002. Sulfur and chlorine play a non-acid base role in periparturient calcium homeostasis. J. Dairy Sci. 85:3444-3453. https://doi.org/10.3168/jds.S0022 $-0302(02) 74432-9$.

Roche, J. R., A. J. Sheahan, L. M. Chagas, and D. P. Berry. 2006d. Short communication: Genetic selection for milk production increases plasma ghrelin in dairy cows. J. Dairy Sci. 89:3471-3475. https://doi.org/10.3168/jds.S0022-0302(06)72385-2.

Roche, J. R., A. J. Sheahan, L. M. Chagas, and D. P. Berry. 2007b. Concentrate supplementation reduces postprandial plasma ghrelin in grazing dairy cows: A possible neuroendocrine basis for reduced pasture intake in supplemented cows. J. Dairy Sci. 90:1354-1363. https://doi.org/10.3168/jds.S0022-0302(07)71622-3.

Roche, J. R., L. R. Turner, J. M. Lee, D. C. Edmeades, D. J. Donaghy, K. A. Macdonald, J. W. Penno, and D. P. Berry. 2009b. Weather, herbage quality and milk production in pastoral systems. 2. Temporal patterns and intra-relationships in herbage quality and mineral concentration parameters. Anim. Prod. Sci. 49:200. https:// doi.org/10.1071/EA07308.

Roche, J. R., S. P. Washburn, D. P. Berry, D. J. Donaghy, and B. Horan. 2017b. Seasonal pasture-based dairy production systems. Pages 99-114 in Large Dairy Herd Management. 3rd ed. D. K. Beede, ed. American Dairy Science Association, Champaign, IL.

Scott, J. 1997. Ruakura research and its contribution to agriculture. Pages 182-185 in Belonging to the Land; Te hononga ki te whenua; People and Places in the Waikato Region. E. Stokes and M. Begg, ed. Waikato Branch, New Zealand Geographical Society, Hamilton, New Zealand.

Shannon, P. 1962. Effect of additions of volatile fatty acids on the viability and fertility of bovine semen. Nature 196:1225-1226.

Shannon, P. 1964. Effect of diluents containing glycine, and glycine and glycerol on the fertility of diluted bovine semen. N. Z. J. Agric. Res. 7:357-363.

Shannon, P. 1965a. Contribution of seminal plasma, sperm numbers, and gas phase to dilution effect of bovine spermatozoa. J. Dairy Sci. 48:1362-1365.

Shannon, P. 1965b. Presence of a heat-labile toxic protein in bovine seminal plasma. J. Dairy Sci. 48:1362-1365.

Shannon, P., and B. Curson. 1972. Toxic effect and action of dead sperm on diluted bovine semen. J. Dairy Sci. 55:614-620. https:// doi.org/10.3168/jds.S0022-0302(72)85544-9.

Shannon, P., and B. Cursons. 1983. Effects of egg yolk levels on the fertility of diluted bovine semen stored at ambient temperatures. N. Z. J. Agric. Res. 26:187-189.

Shannon, P., and R. Vishwanath. 1995. The effect of optimal and sub-optimal concentrations of sperm on the fertility of fresh and frozen bovine sperm and a theoretical model to explain the fertility differences. Anim. Reprod. Sci. 62:23-53.

Shephard, R. W. 2005. A comparison of performance of the Ovsynch treatment program between cycling and non-cycling cows within seasonally calving dairy herds. Aust. Vet. J. 83:751-757.

Spelman, R. J., B. J. Hayes, and D. P. Berry. 2013. Use of molecular technologies for the advancement of animal breeding: Genomic selection in dairy cattle populations in Australia, Ireland and New Zealand. Anim. Prod. Sci. 53:869-875. https://doi.org/10.1071/ AN12304. 
Stakelum, G., and P. Dillon. 1991. Influence of sward structure and digestibility on the intake and performance of lactating and growing cattle. Pages 30-42 in Management Issues for the Grassland Farmer in the 1990s. Occasional Symposium of the British Grassland Society, No. 25. C. S. Mayne, ed. British Grassland Society, Hurley, UK.

Stakelum, G., P. Dillon, and J. Murphy. 1988. Supplementary feeding of grazing dairy cows. Pages 25-27 in Moorepark Dairy Farmers' Conference. K. O'Farrell, ed. Fermoy, Co. Cork, Ireland.

Stapledon, R. G. 1924. The seasonal productivity of herbage grasses with particular reference to the influence of different systems of cutting on indigenous and non-indigenous strains respectively. Bulletin Series H No. 3:5-84.

Stapledon, R. G. 1927a. Characters which determine the economic value of grasses. I. Nutritive value and palatability. J. Minist. Agric. 33:1083-1091.

Stapledon, R. G. 1927b. Characters which determine the economic value of grasses. II. Ratio of leaf to stem. J. Minist. Agric. 34:11-19.

Stapledon, R. G. 1927c. Characters which determine the economic value of grasses. III. Tiller production and powers of resistance to repeated defoliation. J. Minist. Agric. 34:146-154.

Stelwagen, K., C. V. C. Phyn, S. R. Davis, J. Guinard-Flament, D Pomiès, J. R. Roche, and J. K. Kay. 2013. Invited review: Reduced milking frequency: Milk production and management implications. J. Dairy Sci. 96:3401-3413. https://doi.org/10.3168/jds.2012-6074.

Stockdale, C. R. 2000. Levels of pasture substitution when concentrates are fed to grazing dairy cows in Northern Victoria. Aust. J. Exp. Agric. 40:913-921.

Strahan, S. R., R. W. Hemken, J. A. Jackson Jr., R. C. Buckner, L. P. Bush, and M. R. Siegel. 1987. Performance of lactating dairy cows fed tall fescue forage. J. Dairy Sci. 70:1228-1234. https://doi.org/ 10.3168/jds.S0022-0302(87)80135-2.

Tainton, N. M. 1973. A comparison of different pasture rotations. Proc. N. Z. Grassl. Assoc. 35:204-210.

Tolosa, M. X., C. W. Caicedo-Caldas, Holmes, and N. Lopez-Villalobos. 2001. Intake, live weight and feed-conversion efficiency of lactating Holstein-Friesian dairy cows which differ genetically in live weight. Proc. N. Z. Soc. Anim. Prod. 61:221-223.

Voisin, A. 1959. Grass Productivity. Crosby, Lockwood and Son Ltd., London, UK.

Wales, W. J., P. T. Doyle, C. R. Stockdale, and D. W. Dellow. 1999. Effects of variations in herbage mass, allowance, and level of supplement on nutrient intake and milk production of dairy cows in spring and summer. Aust. J. Exp. Agric. 39:119-130. https://doi .org/10.1071/EA98151.

Walker, C. G., M. D. Littlejohn, S. Meier, J. R. Roche, and M. D. Mitchell. 2013. DNA methylation is correlated with gene expression during early pregnancy in Bos taurus. Physiol. Genomics 45:276-286. https://doi.org/10.1152/physiolgenomics.00145.2012.

Walker, C. G., M. D. Littlejohn, M. D. Mitchell, J. R. Roche, and S. Meier. 2012. Endometrial gene expression during early pregnancy differs between fertile and subfertile dairy cow strains. Physiol. Genomics 44:47-58. https://doi.org/10.1152/physiolgenomics.00254 .2010
Washburn, S. P., S. L. White, J. T. Green Jr, and G. A. Benson. 2002. Reproduction, mastitis, and body condition of seasonally calved Holstein and Jersey cows in confinement or pasture systems. J. Dairy Sci. 85:105-111.

Weinmann, H. 1948. Underground development and reserves of grasses: A review. J. Br. Grassl. Soc. 3:115-140.

White, S. L., G. A. Benson, S. P. Washburn, and J. T. Green. 2002. Milk production and economic measures in confinement or pasture systems using seasonally calved Holstein and Jersey cows. J. Dairy Sci. 85:95-104. https://doi.org/10.3168/jds.S0022-0302(02)74057 -5 .

Whitehead, D. C. 1995. Grassland Nitrogen. CABI, Wallingford, UK. Wildman, E. E., G. M. Jones, P. E. Wagner, R. L. Boman, H. F. Troutt, and T. N. Lesch. 1982. A dairy cow body condition scoring system and its relationship to selected production characteristics. J. Dairy Sci. 65:495-501. https://doi.org/10.3168/jds.S0022 $-0302(82) 82223-6$

Woodman, H. E., and D. B. Norman. 1932. Nutritive value of pasture. IX. The influence of the intensity of grazing on the yield, composition and nutritive value of pasture herbage (Part IV). J. Agric. Sci. 22:852-873

Woodman, H. E., D. B. Norman, and J. W. Bee. 1928. Nutritive value of pasture. III. The influence of the intensity of grazing on the composition and nutritive value of pasture herbage (Part I). J. Agric. Sci. 18:266-296.

Woodman, H. E., D. B. Norman, and J. W. Bee. 1929. Nutritive value of pasture. IV. The influence of the intensity of grazing on the yield, composition and nutritive value of pasture herbage (Part II). J. Agric. Sci. 19:236-265.

Woodman, H. E., D. B. Norman, and M. H. French. 1931. Nutritive value of pasture. VII. The influence of the intensity of grazing on the yield, composition and nutritive value of pasture herbage (Part III). J. Agric. Sci. 21:267-321.

Woodward, S. L., K. A. Macdonald, W. A. Carter, J. P. J. Eerens, and J. R. Crush. 2001. Milksolids production from different combinations of perennial ryegrass and white clover cultivars: II Milksolids production and farm profitability. Proc. N. Z. Grassl. Assoc. 63:97-102.

Woodward, T. E. 1936. The quantities of grass that dairy cows will graze. J. Dairy Sci. 19:347-357. https://doi.org/10.3168/jds.S0022 -0302(36)93075-8.

$\mathrm{Xu}, \mathrm{Z}$. Z. 2014. Application of liquid semen technology improves conception rate of sex-sorted semen in lactating dairy cows. J. Dairy Sci. 97:7298-7304.

Xu, Z. Z., and L. J. Burton. 2003. Reproductive performance of dairy cows in New Zealand: Monitoring fertility report. http://www.lic .co.nz/user/file/Monitoring fertility report for distribution.pdf.

Xu, Z. Z., D. J. McKnight, R. Vishwanath, C. J. Pitt, and L. J. Burton. 1998. Estrus detection using radiotelemetry of visual observation and tail painting for dairy cows on pasture. J. Dairy Sci. 81:2890-2896. 


\section{APPENDIX}

Table A1. Timeline of grazing research and pertinent discoveries between 1917 and 2017

\begin{tabular}{|c|c|c|}
\hline Date & Milestone & Reference \\
\hline 1917 & $\begin{array}{l}\text { Where it all begins: } \\
\text { - Herd sizes are }<30 \text { cows } \\
\text { Hay is the predominant conservation method for grass } \\
\text { - Set-stocking (night and day paddocks) } \\
\text {. Dual-purpose breeds (beef and dairy) } \\
\text { - Primary dairy breed is Shorthorn }\end{array}$ & $\begin{array}{l}\text { Atkins, 2016; Anonymous, } \\
\text { 1924; Blaxter and } \\
\text { Robertson, 1995; McCloy, } \\
2014\end{array}$ \\
\hline 1919 & $\begin{array}{l}\text { Welsh plant breeding station is established at Aberystwyth with Sir } \\
\text { George Stapledon as director. Work focuses on breeding forages for } \\
\text { different purposes (e.g., grazing, hay-making). }\end{array}$ & $\begin{array}{l}\text { Raymond, 1981; Lazenby, } \\
1981\end{array}$ \\
\hline $1920 s$ & $\begin{array}{l}\text { Inherently low } \mathrm{P} \text { and } \mathrm{pH} \text { status of soils is addressed via a major drive } \\
\text { to improve soil fertility through the addition of superphosphate and } \\
\text { lime to increase pasture and animal productivity. }\end{array}$ & $\begin{array}{l}\text { Blaxter and Robertson, } \\
1995\end{array}$ \\
\hline $1920 s$ & $\begin{array}{l}\text { A significant uptake of milk recording occurs to enable selection of } \\
\text { cows for higher milk yields. }\end{array}$ & $\begin{array}{l}\text { Anonymous, 1924; Atkins, } \\
2016\end{array}$ \\
\hline 1924 & $\begin{array}{l}\text { Stapledon highlighted the importance of leaf proportion for feed } \\
\text { value; as intervals between grazings increase, the proportion of green } \\
\text { leaf blade is reduced. }\end{array}$ & Stapledon, 1924 \\
\hline 1927 & First International Grassland Congress is held in Leipzig, Germany. & McMeekan, 1953 \\
\hline 1928 & $\begin{array}{l}\text { World Dairy Congress, Boutflour proposed that the } 4 \text { factors limiting } \\
\text { production were (1) lack of control of indigestible fiber; (2) lack of } \\
\text { control of DMl; (3) neglect of the transition cow; and (4) infrequent } \\
\text { milking. }\end{array}$ & Boutflour, 1928 \\
\hline 1928-1932 & $\begin{array}{l}\text { Frequent defoliation is reported to result in higher concentrations of } \\
\text { nutrients. }\end{array}$ & $\begin{array}{l}\text { Woodman et al., 1928, } \\
\text { 1929, 1931; Woodman and } \\
\text { Norman, } 1932\end{array}$ \\
\hline Early 1930s & $\begin{array}{l}\text { The first electric fences are developed in the United States for } \\
\text { livestock control. }\end{array}$ & Jones, 1988 \\
\hline Mid 1930s & $\begin{array}{l}\text { Bill Gallagher modifies US electric fence chargers to control his horse } \\
\text { and dairy cows. }\end{array}$ & Jones, 1988 \\
\hline 1936 & $\begin{array}{l}\text { Grass growth is reported to cease when soil temperatures } \angle 5^{\circ} \mathrm{C} \text {, and } \\
\text { nitrification slows between } 5 \text { and } 8^{\circ} \mathrm{C} \text {. Pasture growth is increased at } \\
\text { lower temperatures by applying } \mathrm{N} \text { fertilizer. }\end{array}$ & Lazenby, 1981 \\
\hline 1937 & $\begin{array}{l}\text { The subdivision of larger areas into smaller paddocks and utilization } \\
\text { of rotational grazing is widespread as a means to manage growth in } \\
\text { New Zealand. }\end{array}$ & Holford, 1937 \\
\hline
\end{tabular}


Table A1 (Continued). Timeline of grazing research and pertinent discoveries between 1917 and 2017

\begin{tabular}{|c|c|c|}
\hline Date & Milestone & Reference \\
\hline Late $1930 \mathrm{~s}$ & $\begin{array}{l}\text { "Young Farmers" clubs are established in New Zealand as a way to } \\
\text { share learning and experiences. }\end{array}$ & Holford, 1937 \\
\hline 1939 & $\begin{array}{l}\text { Ruakura Experimental Station converted from teaching to applied } \\
\text { experimentation. }\end{array}$ & Scott, 1997 \\
\hline 1930-1940s & $\begin{array}{l}\text { Shift from Shorthorn cattle to Friesian in UK and Ireland and to Jersey } \\
\text { in New Zealand. }\end{array}$ & Atkins, 2016 \\
\hline 1941 & $\begin{array}{l}\text { J.F. James reported similar conception rates with Al and natural } \\
\text { mating in research. }\end{array}$ & James, 1941 \\
\hline 1943 & $\begin{array}{l}\text { C.P.McMeekan becomes superintendent (and later director) of } \\
\text { Ruakura Experimental Station (Waikato region, New Zealand). }\end{array}$ & Scott, 1997 \\
\hline 1944 & "Macra na Feirme" established in Ireland as young farmers clubs. & http://www.macra.ie/ \\
\hline 1945 & $\begin{array}{l}\text { In New Zealand, McMeekan began advocating for rotational } \\
\text { grazing in a long-term experiment ( } 12 \mathrm{yr} \text { ) that compared rotational } \\
\text { (controlled) and set-stocking (uncontrolled). }\end{array}$ & McMeekan, 1960 \\
\hline 1946 & $\begin{array}{l}\text { Extremely seasonal nature of breeding season is viewed as an } \\
\text { "insurmountable barrier" to commercial Al. }\end{array}$ & James, 1946 \\
\hline 1948 & $\begin{array}{l}\text { A comprehensive review of plant carbohydrate metabolism } \\
\text { establishes the need for a rest period between grazing events and } \\
\text { support for rotational grazing grows. }\end{array}$ & Weinmann, 1948 \\
\hline 1949 & $\begin{array}{l}\text { A debate at International Grasslands Congress identifies a greater } \\
\text { benefit of } \mathrm{N} \text { fertilizers in Europe than New Zealand because of a } \\
\text { shorter growing season for legumes in Europe. }\end{array}$ & \\
\hline 1950 & $\begin{array}{l}\text { Annual pasture DM yields increase with inter-grazing interval (i.e., } \\
\text { rotation), which leads to the hypothesis that animal production is } \\
\text { greater under rotational grazing compared with set-stocking. }\end{array}$ & $\begin{array}{l}\text { McMeekan, 1947, 1957, } \\
1960\end{array}$ \\
\hline 1950 & $\begin{array}{l}\text { Research facilities to investigate digestibility of pasture are } \\
\text { established at Hurley, United Kingdom. }\end{array}$ & Raymond, 1981 \\
\hline 1950 & Tetraploid ryegrasses are bred in New Zealand. & Hunt and Easton, 1989 \\
\hline 1951 & $\begin{array}{l}\text { Nitrogen fertilizer does not accelerate leaf appearance but strongly } \\
\text { influences leaf size and tillering. }\end{array}$ & Whitehead, 1995 \\
\hline 1952 & $\begin{array}{l}\text { Ron Sharp, a New Zealand dairy farmer, develops the herringbone } \\
\text { milking parlor design. }\end{array}$ & McCloy, 2014 \\
\hline 1955 & $\begin{array}{l}\text { R.W. Brougham is the first to report that regrowth of pasture following } \\
\text { defoliation conforms to a sigmoidal or S-shaped curve. }\end{array}$ & Brougham, 1955 \\
\hline
\end{tabular}


Table A1 (Continued). Timeline of grazing research and pertinent discoveries between 1917 and 2017

\begin{tabular}{|c|c|c|}
\hline Date & Milestone & Reference \\
\hline 1956 & $\begin{array}{l}\text { R.W. Brougham suggests that control of management of rotational } \\
\text { grazing could be achieved using sward height before and after } \\
\text { grazing. }\end{array}$ & Brougham, 1957 \\
\hline 1956 & $\begin{array}{l}\text { McMeekan reports no advantage to strip grazing (offering only } \\
\text { enough pasture for a single feed between milkings) or grazing the } \\
\text { whole paddock. }\end{array}$ & McMeekan, 1957, 1960 \\
\hline 1957 & $\begin{array}{l}\text { McMeekan reports an interaction between stocking rate and method } \\
\text { of grazing (set-stocked vs. rotational). }\end{array}$ & $\begin{array}{l}\text { McMeekan and Walshe, } \\
\text { 1963; Carter, } 1964\end{array}$ \\
\hline 1959 & $\begin{array}{l}\text { Voisin publishes his book, Grass Productivity, encapsulating his } \\
\text { thoughts on rotational grazing. }\end{array}$ & Voisin, 1959 \\
\hline 1959 & $\begin{array}{l}\text { "An Fóras Talúntais" (later Teagasc) is established in Ireland and } \\
\text { the Moorepark Research Station is dedicated to dairy production } \\
\text { research. }\end{array}$ & \\
\hline 1960 & McMeekan publishes landmark treatise, Grass to Milk. & McMeekan, 1960 \\
\hline 1960 & $\begin{array}{l}\text { First grassland experiments begin at Moorepark (Ireland) comparing } \\
\text { rotational grazing with set-stocking. }\end{array}$ & $\begin{array}{l}\text { P.G. Dillon (personal } \\
\text { communication) }\end{array}$ \\
\hline 1960 & $\begin{array}{l}\text { Autumn-saved pasture as a method of conserving pasture in situ in } \\
\text { late autumn comes into vogue. }\end{array}$ & McMeekan, 1960 \\
\hline $1960 s$ & Merit testing of pasture plant varieties is conducted. & Raymond, 1981 \\
\hline 1960 & $\begin{array}{l}\text { Ryegrass tillers are shown to carry an average of } 3 \text { live leaves at all } \\
\text { spacings and nitrogen levels. }\end{array}$ & $\begin{array}{l}\text { Davies, 1977; Fulkerson and } \\
\text { Donaghy, } 2001\end{array}$ \\
\hline 1963 & $\begin{array}{l}\text { The interaction between grazing method and stocking rate is } \\
\text { confirmed. At low stocking rates, no difference is found between } \\
\text { rotational grazing and continuous grazing. At high stocking rates, } \\
\text { rotational grazing allows a } 10 \% \text { increase in stocking rate. }\end{array}$ & $\begin{array}{l}\text { McMeekan and Walshe, } \\
1963\end{array}$ \\
\hline 1963 & $\begin{array}{l}\text { The "unshortable" electric fence for livestock control is developed by } \\
\text { D. Phillips; it increases the range of fencing and decreases the cost by } \\
\sim 90 \% \text {. }\end{array}$ & Jones, 1988 \\
\hline $1960 s$ & $\begin{array}{l}\text { Cow breeds in use continue to change. By } 1970,76 \% \text { of cows in the UK } \\
\text { are Friesian and 3\% Shorthorn. }\end{array}$ & Atkins, 2016 \\
\hline Late 1960s & $\begin{array}{l}\text { White clover is reported to have consistently higher digestibility than } \\
\text { ryegrass. }\end{array}$ & Raymond, 1981 \\
\hline 1969 & $\begin{array}{l}\text { Campbell reports an increase in pasture DM yield with rotation } \\
\text { length. }\end{array}$ & Campbell, 1969 \\
\hline
\end{tabular}


Table A1 (Continued). Timeline of grazing research and pertinent discoveries between 1917 and 2017

\begin{tabular}{|c|c|c|}
\hline Date & Milestone & Reference \\
\hline 1969 & Hutton and Parker confirm the need to fully feed transition cows. & Hutton and Parker, 1973 \\
\hline Early 1970s & $\begin{array}{l}\text { The substitution of supplements for pasture is quantified in } \\
\text { many countries; grazing time declines by } 15 \text { to } 22 \mathrm{~min} / \mathrm{kg} \text { of DM } \\
\text { supplement eaten. }\end{array}$ & $\begin{array}{l}\text { Leaver, 1985; Bargo et al., } \\
\text { 2003; Stockdale, } 2000\end{array}$ \\
\hline 1973 & $\begin{array}{l}\text { It is established that grazing should not be delayed beyond the } \\
\text { development of a full canopy (i.e., ceiling yield). }\end{array}$ & Davies, 1977 \\
\hline 1973 & $\begin{array}{l}\text { Submission rate during the first } 4 \mathrm{wk} \text { of seasonal breeding is } \\
\text { identified as key management success variable. }\end{array}$ & $\begin{array}{l}\text { Macmillan and Watson, } \\
1973\end{array}$ \\
\hline 1977 & Ceiling pasture yield is reached after 3 leaf appearance intervals. & $\begin{array}{l}\text { Davies, 1977; Fulkerson and } \\
\text { Donaghy, } 2001\end{array}$ \\
\hline 1977 & Tail-painting for estrus detection is first introduced. & $\begin{array}{l}\text { Macmillan and Curnow, } \\
1977\end{array}$ \\
\hline 1970 s & Sperm dose rate is reduced from 25 million to 1 million. & $\begin{array}{l}\text { Shannon and Vishwanath, } \\
1995\end{array}$ \\
\hline Late 1970s & Magnesium supplementation reduces milk fever in grazing cows. & Roche and Berry, 2006 \\
\hline 1979 & $\begin{array}{l}\text { The spring gate is developed for electric fences, removing the last } \\
\text { impediment to their use on farm. }\end{array}$ & Jones, 1988 \\
\hline 1981 & Cow DMI is close to maximum with 8 - to $10-\mathrm{cm}$ postgrazing residuals. & \\
\hline 1981 & $\begin{array}{l}\text { Endophyte is reported to cause ryegrass staggers in sheep; Lolitrem B } \\
\text { is isolated as causal factor. }\end{array}$ & Harvey, 1983 \\
\hline 1982 & $\begin{array}{l}\text { Seminal work by Bryant and L'Huillier determines how much feed } \\
\text { should be on the farm in spring and how best to achieve this. This } \\
\text { work leads to the development of the autumn and spring rotation } \\
\text { planners. }\end{array}$ & Bryant and L'Huillier, 1986 \\
\hline 1982 & Endophyte is reported to protect ryegrass from insect attack. & Popay and Rowan, 1994 \\
\hline 1980s onward & $\begin{array}{l}\text { Novel endophytes are developed that offer insect protection but have } \\
\text { fewer or no negative effects on dairy cattle. }\end{array}$ & $\begin{array}{l}\text { Bluett et al., 2003; Milne, } \\
2007\end{array}$ \\
\hline 1985 & $\begin{array}{l}\text { Initiation of experiment comparing Canadian and New Zealand dairy } \\
\text { sires that investigated genetics } \times \text { environment interaction. }\end{array}$ & Peterson, 1988 \\
\hline Late 1980s & $\begin{array}{l}\text { A series of experiments by Stakelum and Dillon in Ireland quantifies } \\
\text { the longer-term effect of grazing management on pasture quality. }\end{array}$ & Stakelum and Dillon, 1991 \\
\hline 1990 & Jersey versus Friesian breed comparison experiment is undertaken. & Ahlhorn and Bryant, 1992 \\
\hline
\end{tabular}


Table A1 (Continued). Timeline of grazing research and pertinent discoveries between 1917 and 2017

\begin{tabular}{|c|c|c|}
\hline Date & Milestone & Reference \\
\hline Early 1990s & $\begin{array}{l}\text { Farmers begin reporting poor reproduction results with modern cows. } \\
\text { General feeling that breeding for or against fertility traits was not } \\
\text { possible due to its low heritability. }\end{array}$ & Harris and Kolver, 2001 \\
\hline 1991 & $\begin{array}{l}\text { Controlled internal drug releasing (CIDR) insert for vaginal } \\
\text { administration of progesterone is developed. }\end{array}$ & $\begin{array}{l}\text { Macmillan and Peterson, } \\
1993\end{array}$ \\
\hline 1994 & $\begin{array}{l}\text { Irish and Australian experiments begin to compare North American } \\
\text { and Dutch genotypes of Holstein-Friesian with local genotypes. } \\
\text { Comparisons continue in different formats for } 15 \mathrm{yr} \text { in Ireland and } \\
\text { New Zealand. }\end{array}$ & $\begin{array}{l}\text { Buckley et al., 2000; } \\
\text { Fulkerson et al., 2001; } \\
\text { Kennedy et al. 2002; Horan } \\
\text { et al., 2005a,b,c }\end{array}$ \\
\hline 1995 & $\begin{array}{l}\text { The importance of calving date in maximizing milk production from } \\
\text { pasture is defined. }\end{array}$ & Dillon et al., 1995 \\
\hline 1996 & $\begin{array}{l}\text { A set of management decision rules to optimize milk production } \\
\text { in seasonal calving dairy systems is developed in New Zealand by } \\
\text { Macdonald and Penno. }\end{array}$ & $\begin{array}{l}\text { Macdonald and Penno, } \\
1998\end{array}$ \\
\hline 1997 & $\begin{array}{l}\text { Kolver and Muller report that primary limiting nutritional factor in } \\
\text { grazing dairy cows is intake of metabolizable energy. }\end{array}$ & Kolver and Muller, 1998 \\
\hline 1997 onward & $\begin{array}{l}\text { The origin of metabolizable energy does not affect milk production } \\
\text { in moderate yielding cows. Carbohydrate course (i.e., sugar, starch, or } \\
\text { fiber) is unimportant. }\end{array}$ & $\begin{array}{l}\text { Carruthers et al., 1997; } \\
\text { Roche et al., 2010; Higgs et } \\
\text { al., } 2013\end{array}$ \\
\hline 2000 & $\begin{array}{l}\text { Temporal changes in pasture DCAD through the year and its effect on } \\
\text { cow urine } \mathrm{pH} \text { defined. }\end{array}$ & Roche et al., 2000 \\
\hline 2000 & $\begin{array}{l}\text { Comparative stocking rate is defined to allow optimum stocking rate } \\
\text { to be calculated in different places. }\end{array}$ & Macdonald et al., 2008a \\
\hline 2000 & Higher stocking rates do not increase nitrate leaching. & $\begin{array}{l}\text { Roche et al., 2016; Huebsch } \\
\text { et al., } 2013\end{array}$ \\
\hline Late 1990s-2000s & $\begin{array}{l}\text { Novel endophytes are developed that have insect protection but very } \\
\text { little effect on dairy cow health and heat stress. }\end{array}$ & Milne, 2007 \\
\hline 2003 & $\begin{array}{l}\text { DCAD is not a practical solution to milk fever in grazing cows because } \\
\text { base DCAD is too high. }\end{array}$ & Roche et al. 2003a,b \\
\hline 2006 & $\begin{array}{l}\text { Effect of feed intensification on nitrate leaching is defined. Increasing } \\
\text { the amount of feed imported from off-farm to increase stocking rate } \\
\text { increases nitrate leaching. }\end{array}$ & Ledgard et al., 2006 \\
\hline $2000 \mathrm{~s}$ & $\begin{array}{l}\text { Genotype } \times \text { diet interaction is identified. Holstein-Friesians of } \\
\text { North American and Dutch origin have lower } 6 \text {-wk in calf rate than } \\
\text { New Zealand Friesian cows, but have a lower substitution rate of } \\
\text { supplement for pasture and a greater immediate milk production } \\
\text { response. }\end{array}$ & $\begin{array}{l}\text { Horan et al., 2005c; } \\
\text { Macdonald et al., 2008b }\end{array}$ \\
\hline
\end{tabular}


Table A1 (Continued). Timeline of grazing research and pertinent discoveries between 1917 and 2017

\begin{tabular}{|l|l|l|}
\hline Date & Milestone & Reference \\
\hline 2001 & $\begin{array}{l}\text { Grazing studies conclude that DM and milk production/hectare are } \\
\text { maximized when pastures are grazed between the emergence of the } \\
\text { second and third leaf on ryegrass plants and postgrazing residuals } \\
\text { are between 3.5 and 4.0 cm. Subsequent studies defined these key } \\
\text { criteria for orchard grass, tall fescue, and prairie grass. }\end{array}$ & $\begin{array}{l}\text { Donaghy, 1998; Fulkerson } \\
\text { and Donaghy, 2001 }\end{array}$ \\
\hline 2000 s & $\begin{array}{l}\text { Breeding indices that accounted for important functional traits as well } \\
\text { as production are developed in Ireland and New Zealand. Followed by } \\
\text { United Kingdom and United States in 2010s. }\end{array}$ & $\begin{array}{l}\text { Gay et al., 2014; } \\
\text { Spelman et al., 2013 }\end{array}$ \\
\hline 2005 & $\begin{array}{l}\text { Transition cow experiments indicate a very small effect of precalving } \\
\text { DMl on milk production. Subsequent work concludes that cows } \\
\text { should have a BCS of 5.0 at calving (10-point scale) and consume 80 } \\
\text { to 90\% of requirements during the month before calving. }\end{array}$ & $\begin{array}{l}\text { Roche et al., 2009a, 2013, } \\
\text { 2015 }\end{array}$ \\
\hline 2011 & $\begin{array}{l}\text { Pasture Profit Index is developed in Ireland to provide a breeding } \\
\text { index for perennial ryegrass and to allow cultivar comparisons. }\end{array}$ & Ramsbottom et al., 2015 \\
\hline 2015 & $\begin{array}{l}\text { Analyses of economic databases identify an increase in fixed costs } \\
\text { when grazing systems are intensified with imported feed; on average, } \\
\text { total costs increase by 150\% of the feed cost. Furthermore, marginal } \\
\text { responses to imported feeds on farm are 40\% less than those } \\
\text { reported in research trials. }\end{array}$ & \\
\hline 2016 & Forage Value Index is subsequently developed in New Zealand. & \\
\hline
\end{tabular}

